Pontifícia Universidade Católica $_{\text {mat }}$

Andrés Esteban Cerón Cortés

\title{
Evaluation of the coefficients of thermal expansion and phase transitions in the $\mathrm{Al}_{2-\mathrm{x}} \mathrm{In}_{\mathrm{x}} \mathrm{W}_{3} \mathrm{O}_{12}$ system
}

\section{Dissertação de Mestrado}

Dissertation presented to the Programa de PósGraduação em Engenharia de Materiais e de Processos Químicos e Metalúrgicos of PUC-Rio in partial fulfillment of the requirements for the degree of Mestre em Engenharia de Materiais e de Processos Químicos e Metalúrgicos.

Advisor: Prof. Bojan Marinkovic

Rio de Janeiro

September 2021 


\section{Evaluation of the coefficients of thermal expansion and phase transitions in the $\mathrm{Al}_{2-\mathrm{x}} \ln _{\mathrm{x}} \mathrm{W}_{3} \mathrm{O}_{12}$ system}

Dissertation presented to the Programa de Pósgraduação em Engenharia de Materiais e de Processos Químicos e Metalúrgicos of PUC-Rio in partial fulfillment of the requirements for the degree of Mestre em Engenharia de Materiais e de Processos Químicos e Metalúrgicos. Approved by the undersigned Examination Committee.

Prof. Bojan Marinkovic Advisor Departamento de Engenharia Química e de Materiais - PUC-Rio

Prof. Roberto Ribeiro de Avillez Departamento de Engenharia Química e de Materiais - PUC-Rio

Profa. Paula Mendes Jardim Departamento de Engenharia Metalúrgica e de Materiais - UFRJ 
All rights reserved.

Andrés Esteban Cerón Cortés

Majored as a Technologist in Industrial Mechanics by the ECCI University, in 2017, Bogotá, Colombia. Major in Mechanical Engineering by the ECCI University, in 2019, Bogotá, Colombia.

Bibliographic data

Cerón Cortés, Andrés Esteban

Evaluation of the coefficients of thermal expansion and phase transitions in the $\mathrm{Al}_{2-\mathrm{x}} \mathrm{In}_{\mathrm{x}} \mathrm{W}_{3} \mathrm{O}_{12}$ system / Andrés Esteban Cerón Cortés ; advisor: Bojan Marinkovic. - 2021.

79 f. : il. color. ; $30 \mathrm{~cm}$

Dissertação (mestrado)-Pontifícia Universidade Católica do Rio de Janeiro, Departamento de Engenharia Química e de Materiais, 2021.

Inclui bibliografia

1. Engenharia Química e de Materiais - Teses. 2. Expansão térmica próxima a zero. 3. $\mathrm{Al}_{2-x} \ln _{\mathrm{x}} \mathrm{W}_{3} \mathrm{O}_{12}$. 4. Transições de fase. 5. Coeficiente de Expansão Térmica (CET). 6. Higroscopicidade. I. Marinkovic, Bojan. II. Pontifícia Universidade Católica do Rio de Janeiro. Departamento de Engenharia Química e de Materiais. III. Título.

CDD: 620.11 
"Porque el amor es la certeza de la vida" To my parents, Zoila Cortés and Flavio Cerón. To my sisters, Carolina and Nathalia. To my brother, Oscar. 


\section{Acknowledgments}

To my advisor, professor Bojan Marinkovic, for his infinite patience and time dedicated to this project, especially for your support, trust in me and constant motivation at times when I didn't even do it. Professor, I learned from you the value of excellence formation that every researcher and professional must have, I am infinitely grateful for your knowledge and teachings throughout this time. Receive from me all my admiration and respect for you.

To Ceramic Materials research group, especially Anja Dosen, Juliana Viol and Fabian Orozco. Thank you for your time, patience, support and contributions.

To Mary Anne White, Michael Johnson and Victoria Blair for their contributions to this research and their participation in our scientific article.

To the ceramic materials research group at PUC-Rio, especially Mayara Marzano, Thaís Mortimer, Esteban Moreno, Lucas Almeida and Luciano Monteiro for their contributions, company and teachings throughout this time.

To the Pontifical Catholic University of Rio de Janeiro, PUC-Rio, for allowing me access to spaces, equipment, infrastructure and work personnel. Thank you very much for the opportunity for academic and personal enrichment.

To the Conselho Nacional de Desenvolvimento Científico e Tecnológico (CNPQ) for the master degree scholarship.

To the government of Brazil, the city of Rio de Janeiro, the US Army Research Laboratory and the NSERC to finance this project.

To the ECCI University and its work team, especially to Dr. Margarita Habrán, Dr. Juan Sebastian Solís and my friend and professor, Vladimir Silva Leal. Without you this path could not have been known and traveled.

To my family. To my parents Flavio and Zoila, to my siblings Adriana, Oscar and Nathalia, to my nephews Jose and Antonella and to my grandmother Fanny, for teaching me the value of the words love, unconditionality, support and loyalty. You are an example of life and professionalism. Without you none of this 
would have been possible. Thank you for giving me the honor of allowing me to call you family. I love you, this is by you and for you.

To my friends and my other family in Colombia Cristian Cortés, Daniel Contreras, Diana Pabón, Camilo Parra, Camilo Hurtado, Ángela Ordoñez, Diego Zapata, Alexandra Martinez, Gustavo Rivera, Jorge Urrego, Carlos Villarreal, Mario Fajardo, Juan Pablo España, Esteban Guerrero and Wendy Murcia, for each contribution that they did in this process, for their words of encouragement, company and solidarity, and for showing me that not all distance is absence nor all silence is oblivion.

To my friends and my other family in Brazil Esteban Moreno, Lucas Almeida, Juan David Caicedo, Maria Guateque, Fabian Orozco and Giulia Simão, for their help upon my arrival in Brazil, their company throughout this time and their friendship.

Finally, thank God for never abandoning me, always taking care of me and making all of this possible.

This study was financed in part by the Coordenação de Aperfeiçoamento de Pessoal de Nível Superior - Brasil (CAPES) - Finance Code 001.

"Vive, ríe, sueña, busca, transforma y lucha, por ese, un mundo mejor" 


\section{Abstract}

Cerón Cortés, Andrés Esteban; Marinkovic, Bojan (Advisor). Evaluation of the coefficients of thermal expansion and phase transitions in $\mathbf{A l}_{2}$-x $\mathbf{I} \mathbf{n}_{\mathbf{x}} \mathbf{W}_{\mathbf{3}} \mathbf{O}_{\mathbf{1 2}}$ system. Rio de Janeiro, 2021. 79 p. Dissertação de mestrado - Departamento de Engenharia Química e de Materiais, Pontifícia Universidade Católica do Rio de Janeiro.

This work aims to study the extrinsic and intrinsic thermal expansion of $\mathrm{Al}_{2}$ ${ }_{\mathrm{x}} \mathrm{In}_{\mathrm{x}} \mathrm{W}_{3} \mathrm{O}_{12}$, its phase transitions and hygroscopicity for the phases: $\mathrm{x}=0.2 ; 0.4$; 0.7 and 1 . The powders were obtained by the co-precipitation method. This technique allows the production of advanced ceramic materials through soft chemical reactions at relatively low temperatures using aqueous solutions as reagents.

The $\mathrm{Al}_{2-\mathrm{x}} \mathrm{In}_{\mathrm{x}} \mathrm{W}_{3} \mathrm{O}_{12}$ family is part of thermomiotic ceramics (from the Greek "thermo" for heat and "mio" for contraction) and belongs to the $\mathrm{A}_{2} \mathrm{M}_{3} \mathrm{O}_{12}$ family ( $\mathrm{A}=$ trivalent cation, $\mathrm{M}=$ hexavalent cation), wich can show negative or near zero thermal expansion. This fact makes this ceramic a potential candidate in applications that require materials with high resistance to thermal shock. In the literature, we found few systematic studies that report parameters of interest in $\mathrm{Al}_{2-\mathrm{x}} \mathrm{In}_{\mathrm{x}} \mathrm{W}_{3} \mathrm{O}_{12}$ system such as the coefficients of thermal expansion (CTE) and its phase transitions. Therefore, the present work aims to determine the intrinsic coefficients of expansion (determined by X-ray diffraction that is relative to variations in the material's lattice parameters) and the extrinsic coefficient of expansion (obtained by dilatometry which takes into account intrinsic and also extrinsic variations in dimension, these later related to microstructural defects) of $\mathrm{Al}_{2-\mathrm{x}} \mathrm{In}_{\mathrm{x}} \mathrm{W}_{3} \mathrm{O}_{12}$, phase transition temperatures (monoclinic to orthorhombic) in the range between $x=0.2$ to $x=1$. In addition, this study intends to report hygroscopicity of this system (using thermogravimetry). The results showed that $\mathrm{Al}_{2-\mathrm{x}} \mathrm{In}_{\mathrm{x}} \mathrm{W}_{3} \mathrm{O}_{12}$ adopted an orthorhombic structure at room temperature (RT) for $\mathrm{x}$ $=0.2 ; 0.4 ; 0.7$ compositions and monoclinic structure for $\mathrm{x}=1$ composition. In $\mathrm{x}$ $=1$ phase, a monoclinic to orthorhombic phase transition occurred close to 200 ${ }^{\circ} \mathrm{C}$. Finally, the $\mathrm{Al}_{2-\mathrm{x}} \mathrm{In}_{\mathrm{x}} \mathrm{W}_{3} \mathrm{O}_{12}$ system presented low hygroscopicity in all four studied phases. 


\section{Keywords}

Near-zero thermal expansion; negative thermal expansion; tungstate; $\mathrm{A}_{2} \mathrm{M}_{3} \mathrm{O}_{12} ; \mathrm{Al}_{2-\mathrm{x}} \mathrm{In}_{\mathrm{x}} \mathrm{W}_{3} \mathrm{O}_{12}$; phase transitions; coefficient of thermal expansion (CTE); hygroscopicity. 


\section{Resumo}

Cerón Cortés, Andrés Esteban; Marinkovic, Bojan (Orientador). Avaliação dos coeficientes de expansão térmica e transições de fase no sistema $\mathrm{Al}_{2}$ ${ }_{\mathbf{x}} \mathbf{I n}_{\mathbf{x}} \mathbf{W}_{3} \mathbf{O}_{12}$. Rio de Janeiro, 2021. 79 p. Dissertação de mestrado - Departamento de Engenharia Química e de Materiais, Pontifícia Universidade Católica do Rio de Janeiro.

Este trabalho tem como objetivo estudar a expansão térmica extrínseca e intrínseca do $\mathrm{Al}_{2-\mathrm{x}} \mathrm{In}_{\mathrm{x}} \mathrm{W}_{3} \mathrm{O}_{12}$, suas transições de fase e higroscopicidade para as fases: $\mathrm{x}=0,2 ; 0,4 ; 0,7$ e 1 . Os pós foram obtidos pelo método de co-precipitação. Esta técnica permite a produção de materiais cerâmicos avançados por meio de reações químicas suaves em temperaturas relativamente baixas usando em solução aquosa.

A família $\mathrm{Al}_{2-\mathrm{x}} \mathrm{In}_{\mathrm{x}} \mathrm{W}_{3} \mathrm{O}_{12}$ faz parte do que se pode classificar como cerâmicas termomióticas (do grego "thermo" para calor e "mio" para contração) e pertence à família $\mathrm{A}_{2} \mathrm{M}_{3} \mathrm{O}_{12}(\mathrm{~A}=$ cátion trivalente, $\mathrm{M}=$ cátion hexavalente $)$, com expansão térmica negativa ou quase zero. Este fato torna esta cerâmica uma candidata potencial em aplicações que requerem materiais com alta resistência ao choque térmico. Na literatura, encontramos poucos estudos sistemáticos que relatam parâmetros de interesse no sistema $\mathrm{Al}_{2-\mathrm{x}} \mathrm{In}_{\mathrm{x}} \mathrm{W}_{3} \mathrm{O}_{12}$, como os coeficientes de expansão térmica (CET) e suas transições de fase. Portanto, o presente trabalho tem como objetivo determinar os coeficientes de expansão intrínsecos (determinados por difração de raios $\mathrm{X}$ que é relativa às variações nos parâmetros de rede do material) e o coeficiente de expansão extrínseco (obtido por dilatometria que leva em consideração a variação intrínseca e também extrínseca, dimensões do material, estas últimas relacionadas a defeitos microestruturais) do sistema $\mathrm{Al}_{2-\mathrm{x}} \mathrm{In}_{\mathrm{x}} \mathrm{W}_{3} \mathrm{O}_{12}$, temperaturas de transição de fase (monoclínica e ortorrômbica) na faixa de $\mathrm{x}=0,2 \mathrm{ax}=1$. Além disso, este estudo pretende relatar a higroscopicidade deste sistema (usando termogravimetria). Os resultados mostraram que o $\mathrm{Al}_{2-\mathrm{x}} \mathrm{In}_{\mathrm{x}} \mathrm{W}_{3} \mathrm{O}_{12}$ adotou uma estrutura ortorrômbica em temperatura ambiente para as composições $\mathrm{x}=0,2 ; 0,4 ; 0,7$ e uma estrutura monoclínica para a composição $x=1$. Na fase $x=1$, uma transição de fase 
monoclínica para ortorrômbica ocorreu perto de $200{ }^{\circ} \mathrm{C}$. Finalmente, o sistema $\mathrm{Al}_{2-\mathrm{x}} \mathrm{In}_{\mathrm{x}} \mathrm{W}_{3} \mathrm{O}_{12}$ apresentou baixa higroscopicidade nas quatro fases estudadas.

\section{Palavras-chave}

Expansão térmica proxima a zero; expansão térmica negativa; tungstato; $\mathrm{A}_{2} \mathrm{M}_{3} \mathrm{O}_{12} ; \mathrm{Al}_{2-\mathrm{x}} \mathrm{In}_{\mathrm{x}} \mathrm{W}_{3} \mathrm{O}_{12}$; transições de fase; coeficiente de expansão térmica (CET); higroscopicidade. 


\section{Content}

1 Introduction

2 Literature review

2.1. Fundamentals of termal expansion

2.1.1. Coefficient of termal expansion CTE 20

2.2. Thermomiotic ceramic materials 21

2.2.1. Dynamic and structural mechanisms of NTE 23

2.2.2. Structural vibrations 24

2.2.3. Families of thermomiotic materials 27

2.2.4. $\mathrm{A}_{2} \mathrm{M}_{3} \mathrm{O}_{12}$ familiy 28

2.2.5. $\mathrm{A}_{2} \mathrm{M}_{3} \mathrm{O}_{12}$ structure 28

2.2.6. $\mathrm{A}_{2}-\mathrm{x} \mathrm{B}_{\mathrm{x}} \mathrm{M}_{3} \mathrm{O}_{12}$ : a solid solutions in $\mathrm{A}_{2} \mathrm{M}_{3} \mathrm{O}_{12}$ familiy 29

2.2.7. $\mathrm{A}_{2} \mathrm{M}_{3} \mathrm{O}_{12}$ anisotropic, intrinsic and extrinsic thermal expansion 30

2.2.8. Phase transitions in $\mathrm{A}_{2} \mathrm{M}_{3} \mathrm{O}_{12}$ family 31

2.2.9. Effect of partial substitution of cátion $A^{3+}$ on CTE in $\mathrm{A}_{2} \mathrm{M}_{3} \mathrm{O}_{12}$ family

2.2.10. Hygroscopicity

2.3. $\mathrm{Al}_{2-\mathrm{x}} \mathrm{In}_{\mathrm{x}} \mathrm{W}_{3} \mathrm{O}_{12}$ system

2.4. CTE and thermal shock resistance 37

2.5. Synthesis of thermomiotic ceramics 38

2.5.1. Co-precipitation method 38

2.5.2. Conformation 39

$\begin{array}{ll}\text { 2.5.3. Sintering } & 39\end{array}$

3 Objectives $\quad 40$

3.1. General objective 40

3.2. Specific objectives $\quad 40$

4 Materials and methods 41

4.1. Co-precipitation method for the $\mathrm{Al}_{2-\mathrm{x}} \mathrm{In}_{\mathrm{n}} \mathrm{W}_{3} \mathrm{O}_{12}$ 
4.2. Characterization techniques 42

4.2.1. Differencial scanning calorimetry (DSC) 42

4.2.2. Thermogravimetry (TGA) 42

4.2.3. X-ray power diffraction (XRPD) 43

4.2.4. High temperature X-ray power diffraction (HT-XRPD) 43

4.2.5. Dilatometry 43

4.2.6. Density 44

4.2.7. Diffuse reflectance spectroscopy (DRS) 44

5 Results and Discussion $\quad 45$

5.1. Phase composition 45

5.2. Phase transition temperature 48

5.2.1. Phase transition temperature. HT-XRPD technique 48

5.2.2. Phase transition temperature. DSC technique 51

5.2.3. Phase transition temperature. Dilatometry technique 53

5.2.4. Vegard's Law applied to $\mathrm{Al}_{2-\mathrm{x}} \ln _{\mathrm{x}} \mathrm{W}_{3} \mathrm{O}_{12}$ system 55

5.2.5. Phase transition temperature in $\mathrm{Al}_{2-x} \ln _{x} \mathrm{~W}_{3} \mathrm{O}_{12}$ system 56

5.3. Coefficient of thermal expansion CTE 58

5.3.1. Intrinsic CTE 58

5.3.2. Extrinsic CTE 62

5.3.3. CTE in $\mathrm{Al}_{2-\mathrm{x}} \ln _{\mathrm{n}} \mathrm{W}_{3} \mathrm{O}_{12}$ system 62

5.4. Higroscopicity 64

5.5. Density of $\mathrm{Al}_{2-x} \ln _{x} \mathrm{~W}_{3} \mathrm{O}_{12}$

5.6. Effect of the addition of $\operatorname{In}^{3+}$ cation on the UV-Vis absorption in $\mathrm{Al}_{2}$ $x \ln _{x} \mathrm{~W}_{3} \mathrm{O}_{12}$ system 66

6 Conclusions and future works 68

$\begin{array}{ll}7 \text { Referências Bibliográficas } & 70\end{array}$

Appendix A: Supplementary material to support section 5.6

Appendix B: Article published from the results from this Dissertation 79 


\section{Figure list}

Figure 1- Potential energy curves as a function of the interatomic distance ( $r$ ). Harmonic, not continuous line with white spheres. Anharmonic, continuous line with black spheres [1]. As a material experiences changes in temperature, the interatomic distances change, represented by the black spheres. In harmonic potential, the distance is constant.

Figure 2- Schematic representation of vibrational energy levels. (a) Stiffer material and (b) less rigid material [4].

Figure 3- Graphical representation of the thermodynamics of thermal expansion.

The figures show thermodynamic principles behind (a) positive thermal expansion and (b) negative thermal expansion response with increase of temperature [5]. The volumes indicated on the x-axis show the minima of the expression $F+P_{o} V$ versus $V$ isotherm. These are the equilibrium volumes at temperatures $T$ and $T+\delta T$, respectively.

Figure 4- Schematic representation of lattice modes for a chain of atoms. (a) Longitudinal optical, (b) high-energy transverse optical and (c) low-energy transverse acoustic [7].

Figure 5- Schematic representations of (a) longitudinal vibrations (the average distance between the atoms increases due to the anharmonicity of the potential energy curve and changes in temperature), middle-system in equilibrium and (c) transverse vibrations (reduction of the mean distance between atoms, as a consequence negative thermal expansion can be is generated) [1].

Figure 6- Schematic representation of dimensional contraction caused by increase in the temperature of a thermomiotic material and its mechanism of rotation between polyhedra [9]. White spheres represent oxygens with coordination number 2 and black spheres represents metallic cations with coordination number 4 or 6 .

Figure 7- Schematic representation of libration [1]. It is possible to distinguish the true distance and the perceived distance when this phenomenon occurs in M- 
$O$ bonds. The libration cause a reduction of perceived length when the magnitude of the vibration increases.

Figure 8- Representation of $\mathrm{Sc}_{2} \mathrm{~W}_{3} \mathrm{O}_{12}$ crystal structure. It is possible to observe $\mathrm{ScO}_{6}$ octahedral units (blue) connected through vertices with $\mathrm{WO}_{4}$ tetrahedral (green) [6].

Figure 9- Phase transition temperature from monoclinic to orthorhombic structure of some compounds of the $\mathrm{A}_{2} \mathrm{M}_{3} \mathrm{O}_{12}$ family. (a) tungstates and (b) molybdates [6].

Figure 10- CET as a function of $A$ site polyhedral distortion [35].

Figure 11- Fracture in the dome of a ballistic missile as a consequence of the thermal shock to which it was exposed as a result of a Mach 4.6 air flow [47]

Figure 12- Schematic representation of sintering mechanisms for a two particles [50].

Figure 13- XRPD patterns of $\mathrm{Al}_{2-x} \ln _{x} \mathrm{~W}_{3} \mathrm{O}_{12}$ obtained at RT. The Le Bail fit shows that the compositions (a) $x=0.2$, (b) $x=0.5$ and (c) $x=0.7$ coincide with the orthorhombic space group Pbcn. For the composition (d) $x=1$ the Le Bail fit shows that the composition coincides with the monoclinic space group $P 2_{1} / a$. Experimental profiles are represented by black lines, calculated profiles by red lines and difference profiles by green lines. (d) The arrows show typical diffraction lines for the monoclinic system in the $\mathrm{A}_{2} \mathrm{M}_{3} \mathrm{O}_{12}$ family, which are absent in the orthorhombic system.

Figure 14- HT-XRPD patterns of $\mathrm{Al}_{2-x} \ln _{x} \mathrm{~W}_{3} \mathrm{O}_{12}$. For compositions (a) $\mathrm{x}=0.2$, (b) $\mathrm{X}=0.4$ and (c) $\mathrm{x}=0.7$ the structures are orthorhombic from $\mathrm{RT}$ to $400{ }^{\circ} \mathrm{C}$. For composition (d) $x=1$ phase transition from monoclinic to orthorhombic structure occurs at $\sim 250{ }^{\circ} \mathrm{C}$.

Figure 15- HT-XRPD patterns $x=1$ sample at three different temperatures. Arrows mark characteristic peaks for monoclinic system of the $\mathrm{A}_{2} \mathrm{M}_{3} \mathrm{O}_{12}$ family at $\mathrm{RT}$. As the temperature increases, these disappear. Additionally, at high temperatures the separation of the most intense peak in two diffraction lines indicates formation of orthorhombic structure of the $\mathrm{A}_{2} \mathrm{M}_{3} \mathrm{O}_{12}$ family.

Figure 16- DSC curves in the $\mathrm{Al}_{2-\mathrm{x}} \mathrm{In}_{\mathrm{x}} \mathrm{W}_{3} \mathrm{O}_{12}$ for que $\mathrm{x}=0.2,0.4,0.7$ and 1 compositions. (a) cryogenic temperatures, (b) RT and above RT. For the $x=1$ composition, the onset temperature of the monoclinic to orthorhombic phase transition and enthalpy of phase transition are presented. 
Figure 17- Dilatometric curves of $\mathrm{Al}_{2-x} \ln _{x} \mathrm{~W}_{3} \mathrm{O}_{12}$ system. (a) $\mathrm{x}=0.2$, (b) $\mathrm{x}=0.4$, (c) $x=0.7$ and $(d) x=1$. For $x=1$ there is monoclinic to orthorhombic phase transition, situated between $150^{\circ} \mathrm{C}$ and $250{ }^{\circ} \mathrm{C}$.

Figure 18- Vegard Law applied for $\mathrm{Al}_{2-\mathrm{x}} \mathrm{In}_{\mathrm{x}} \mathrm{W}_{3} \mathrm{O}_{12}$ system with $\mathrm{x}=0.2,0.4,0.7$ and 1 . Orthorhombic lattice parameters at $250{ }^{\circ} \mathrm{C}$ as a function of $\mathrm{In}^{3+}$ content are presented.

Figure 19 - Natural logarithmic variations of unit-cell parameters ( $a, b$ and $c$ ) and unit-cell volume as function of temperature for $\mathrm{x}=0.2$ composition in $\mathrm{Al}_{2}$ ${ }_{\mathrm{x}} \mathrm{In}_{\mathrm{x}} \mathrm{W}_{3} \mathrm{O}_{12}$ system.

Figure 20- Natural logarithmic variations of unit-cell parameters (a, b and c) and unit-cell volume as function of temperature for $\mathrm{x}=0.4$ composition in $\mathrm{Al}_{2}$ ${ }_{x} \ln _{x} \mathrm{~W}_{3} \mathrm{O}_{12}$ system.

60

Figure 21- Natural logarithmic variations of unit-cell parameters ( $a, b$ and c) and unit-cell volume as function of temperature for $\mathrm{x}=0.7$ composition in $\mathrm{Al}_{2}$ ${ }_{x} \ln _{x} W_{3} \mathrm{O}_{12}$ system.

60

Figure 22- Natural logarithmic variations of unit-cell parameters ( $a, b$ and $c)$ and unit-cell volume as function of temperature for $\mathrm{x}=1$ monoclinic structure in $\mathrm{Al}_{2}$ $x \ln _{x} W_{3} \mathrm{O}_{12}$ system.

Figure 23- Natural logarithmic variations of unit-cell parameters ( $a, b$ and $c$ ) and unit-cell volume as function of temperature for $\mathrm{x}=1$ orthorhombic structure in $\mathrm{Al}_{2-\mathrm{x}} \mathrm{In} \mathrm{n}_{\mathrm{x}} \mathrm{W}_{3} \mathrm{O}_{12}$ system.

Figure 24- TGA curves of (a) $x=0.2$, (b) $x=0.4$, (c) $x=0.7$ and (d) $x=1$ compositions in $\mathrm{Al}_{2-\mathrm{x}} \ln \times \mathrm{W}_{3} \mathrm{O}_{12}$ system. The curves show weight losses lower than $1 \mathrm{wt} \%$, over the temperature range from $R T$ to $950{ }^{\circ} \mathrm{C}$, for all four phases in $A l_{2-x} \ln _{x} W_{3} O_{12}$ system. 


\section{Table list}

Table 1- Coefficient of thermal expansion $\boldsymbol{\alpha i}$ (intrinsic) and $\boldsymbol{\alpha} \boldsymbol{e}$ (extrinsic) in some compounds within $\mathrm{A}_{2} \mathrm{M}_{3} \mathrm{O}_{12}$ family [18]. 30

Table 2- Linear coefficients of thermal expansion in $\mathrm{Y}_{2-\mathrm{x}} \mathrm{Ce}_{\mathrm{x}} \mathrm{W}_{3} \mathrm{O}_{12}$ [31]. 33

Table 3- Linear coefficients of thermal expansion in $\mathrm{Al}_{2-x} \mathrm{Sc}_{x} \mathrm{~W}_{3} \mathrm{O}_{12}$ [23]. 33

Table 4- $\mathrm{AllnW}_{3} \mathrm{O}_{12}$ relative density reported by Koseva et al [30]. 36

Table 5- Lattice parameters at $\mathrm{RT}$ in $\mathrm{Al}_{2-\mathrm{x}} \mathrm{In}_{\mathrm{x}} \mathrm{W}_{3} \mathrm{O}_{12}$ system 48

Table 6- Phase transition temperature in $\mathrm{Al}_{2-\mathrm{x}} \mathrm{In}_{\mathrm{x}} \mathrm{W}_{3} \mathrm{O}_{12}$ system reported by Koseva et al. [44].

Table 7- Intrinsic CTEs along each crystallographic axis $\left(\alpha_{a}, \alpha_{b}, \alpha_{c}\right)$, average linear CTE $\left(\alpha_{l}\right)$ in $\mathrm{Al}_{2-x} \ln _{x} \mathrm{~W}_{3} \mathrm{O}_{12}$ system and standard deviations for $\mathrm{x}=0.2,0.4,0.7$ and 1 compositions.

Table 8- Extrinsic linear CTE $\left(\alpha_{l}\right)$ in $\mathrm{Al}_{2-\mathrm{x}} \mathrm{In}_{\mathrm{x}} \mathrm{W}_{3} \mathrm{O}_{12}$ system and their respective standard deviations for $\mathrm{x}=0.2,0.4,0.7$ and 1 compositions.

Table 9- Weight losses in $\mathrm{Al}_{2-\mathrm{x}} \mathrm{In}_{\mathrm{x}} \mathrm{W}_{3} \mathrm{O}_{12}$ system for $\mathrm{x}=0.2,0.4,0.7$ and 1 compositions.

65

Table 10- Theoretical, real and relative densities of the sintered pellets within $\mathrm{Al}_{2}$ ${ }_{x} \ln { }_{x} W_{3} \mathrm{O}_{12}$ system.

66

Table 11- Band-gap energy $\mathrm{Eg}$ in $\mathrm{Al}_{2-\mathrm{x}} \mathrm{In}_{\mathrm{x}} \mathrm{W}_{3} \mathrm{O}$ system for $\mathrm{x}=0,0.2,0.4,0.7,1$ and 2 compositions. 


\section{Introduction}

It is known that most of materials present variations in their dimensions when subjected to changes in temperature. Normally, when heated their dimensions increase and when cooled, a decrease in dimensions is observed. However, there is a select group of advanced ceramic materials which has the ability to reduce their dimensions with increase of temperature: thermomiotic ceramics (from the Greek thermos for heat and mio for contraction). These ceramics are oxides and offer possibility of adjusting of coefficient of thermal expansion (CTE) with partial or complete substitution of $A^{3+}$ cation. This property is of interest due to scientific and technological reasons.

Within thermomiotic ceramics there are series of families, among them, $\mathrm{A}_{2} \mathrm{M}_{3} \mathrm{O}_{12}$ family, where $A$ can be a rare earth cation from Ho to Lu, including $\mathrm{Y}$ and Sc or some other trivalent cation such as $\mathrm{Al}^{3+}, \mathrm{Cr}^{3+}, \mathrm{Fe}^{3+}, \mathrm{In}^{3+}$ or $\mathrm{Ga}^{3+}$, while $M$ is a hexavalent cation such as $\mathrm{W}^{6+}$ or $\mathrm{Mo}^{6+}$. These ceramics have negative, low-positive or near-zero $\left(-11 \times 10^{-6}{ }^{\circ} \mathrm{C}^{-1}\right.$ to $-0.11 \times 10^{-6}{ }^{\circ} \mathrm{C}^{-1}$, where $\alpha$ denotes CTE). This behavior occurs as an interplay of bond lengths dilation due to the asymmetry of potential well and transverse vibrational modes which generate a reduction in the volume.

In the $\mathrm{A}_{2} \mathrm{M}_{3} \mathrm{O}_{12}$ family, member $A$ forms octahedra $\left(\mathrm{AO}_{6}\right)$ that share their vertices with member $M$, which forms tetrahedra $\left(\mathrm{MO}_{4}\right)$. These framework arrangement leads to the formation of orthorhombic structures in the space group Pbcn (less dense and with a negative, near-zero or low-positive CTE) or monoclinic with the space group $\mathrm{P} 21 / \mathrm{a}$ (a denser phase with a normal positive CTE). The orthorhombic phase is favored at RT when $A^{3+}$ have a lower electronegativity [1][2]. However, some thermomiotic ceramics show transitions from monoclinic to orthorhombic structure during heating or cooling above RT.

Many studies of members of the $\mathrm{A}_{2} \mathrm{M}_{3} \mathrm{O}_{12}$ family have been reported in which parameters such as intrinsic and extrinsic CTEs, phase transitions temperatures, hygroscopicity, among others have been characterized. 
This dissertation arises from the interest of investigating and characterizing some of the properties of aluminum-indium tungstate $\left(\mathrm{Al}_{2-\mathrm{x}} \mathrm{In}_{\mathrm{x}} \mathrm{W}_{3} \mathrm{O}_{12}\right)$ as a material that is part of the $\mathrm{A}_{2} \mathrm{M}_{3} \mathrm{O}_{12}$ family, still without a thorough study available in literature, as the author is aware of. 


\section{2 \\ Literature review}

\section{1.}

\section{Fundamentals of thermal expansion}

Most materials show changes in their dimensions when exposed to temperature variations. The usual behavior indicates that a material when heated expands and when cooled it contracts. The explanation of the thermal expansion can be understood by means of the curve of potential energy as a function of the interatomic distance. Properties such as thermal expansion of a material are result of the interatomic forces of the material, generating changes in its dimensions as a function of temperature.

Figure 1 shows two potential energy curves, one of them symmetrical and the other asymmetrical. The first is an idealized symmetric potential energy curve which can be considered close to those presented by strong chemical bonds (but not exactly the same, since even the strongest chemical bonds present some asymmetry in the well) which would lead to a low CTE. The second is a realistic asymmetric energy curve, typical for vast majority of chemical bonds, and is the consequence of two energetic terms, attractive and repulsion. When an increase in thermal energy occurs in a system, the harmonicity of the system is altered, and the bonds start to expand due to the intrinsic asymmetry of the curve. As a consequence of this $\alpha \neq 0$ ${ }^{\circ} \mathrm{C}^{-1}[1][3]$.

A more rigid material presents stronger chemical bonds and the energetic distance between the successive vibrational energy levels increases. This behavior characterizes a low heat capacity. Otherwise, a less rigid material presents weaker chemical bonds and the distance between energy levels is decreased. Therefore, these materials present higher heat capacity. This behavior is presented in Figure 2. 


\subsection{1.}

\section{Coefficient of thermal expansion CTE}

The coefficient of thermal expansion (CTE) in a material at constant pressure is defined by equation 1 if it is linear or by equation 2 if it is volumetric. If the energy curve has a greater depth and is more symmetric, the coefficient of thermal expansion will be lower due to the high binding energy.

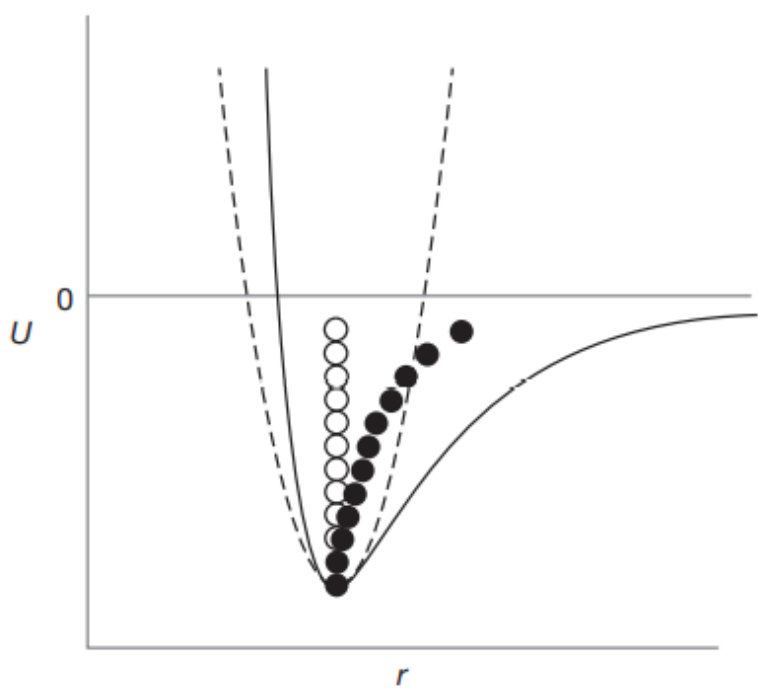

Figure 1- Potential energy curves as a function of the interatomic distance (r). Harmonic, not continuous line with white spheres. Anharmonic, continuous line with black spheres [1]. As a material experiences changes in temperature, the interatomic distances change, represented by the black spheres. In harmonic potential, the distance is constant.

(a)

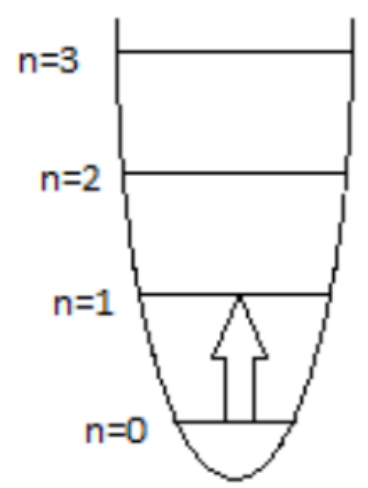

(b)

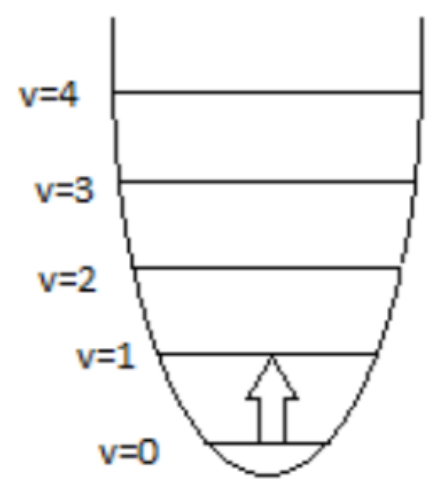

Figure 2- Schematic representation of vibrational energy levels. (a) Stiffer material and (b) less rigid material [4]. 
Equation 1: Linear thermal expansion coefficient

$$
\alpha_{l=} \frac{1}{l}\left(\frac{d l}{d T}\right)_{P}
$$

Equation 2: Volumetric thermal expansion coefficient

$$
\alpha_{v}=\frac{1}{V}\left(\frac{d V}{d T}\right)_{P}
$$

$\boldsymbol{\alpha}_{\boldsymbol{l}}=$ coefficient of linear thermal expansion

$\boldsymbol{\alpha}_{\boldsymbol{v}}=$ volumetric coefficient of thermal expansion

$\boldsymbol{l}=$ initial length

$\boldsymbol{V}=$ initial volume

$\boldsymbol{d} \boldsymbol{l}=$ variation in length

$\boldsymbol{d} \boldsymbol{V}=$ variation in volume

$\boldsymbol{d} \boldsymbol{T}=$ variation in temperature

The materials can present an isotropic or anisotropic CTE. In the isotropic materials the thermal expansion occurs in the same proportion throughout all crystallographic directions. Therefore, a relationship can be established between the linear and volumetric coefficient of thermal expansion for materials with isotropic behavior. This relationship is expressed in equation 3 .

Equation 3: Relationship between and $\boldsymbol{\alpha}_{\boldsymbol{v}}$

$$
\alpha_{v}=3 \alpha_{l}
$$

\section{2.}

\section{Thermomiotic ceramic materials}

The relationship that exists in a material between the volume and the change in volume with respect to the change in temperature is expressed by equation 2 . Through Maxwell's relationships, the link between volume and entropy (S) expressed in equation 4 can be understood, where $\mathrm{K}_{\mathrm{T}}$ is the isothermal compressibility. Compressibility is a property that takes positive values, therefore, changes in volume in a material that is being heated will occur in the direction in which an increase in entropy occurs [5] .

Figure 3 shows the behavior of the thermal expansion in a generic material. At constant pressure, the volume at a certain temperature is determined when the 
expression $F(V, T)+P_{o} V$ is minimized $(\mathrm{F}=$ Helmholtz energy, $\mathrm{V}=$ volume, $\mathrm{T}=$ temperature, $\mathrm{P}_{\mathrm{o}}=$ initial pressure). Thermal expansion in a material occurs in the direction in which the entropy increases [5].
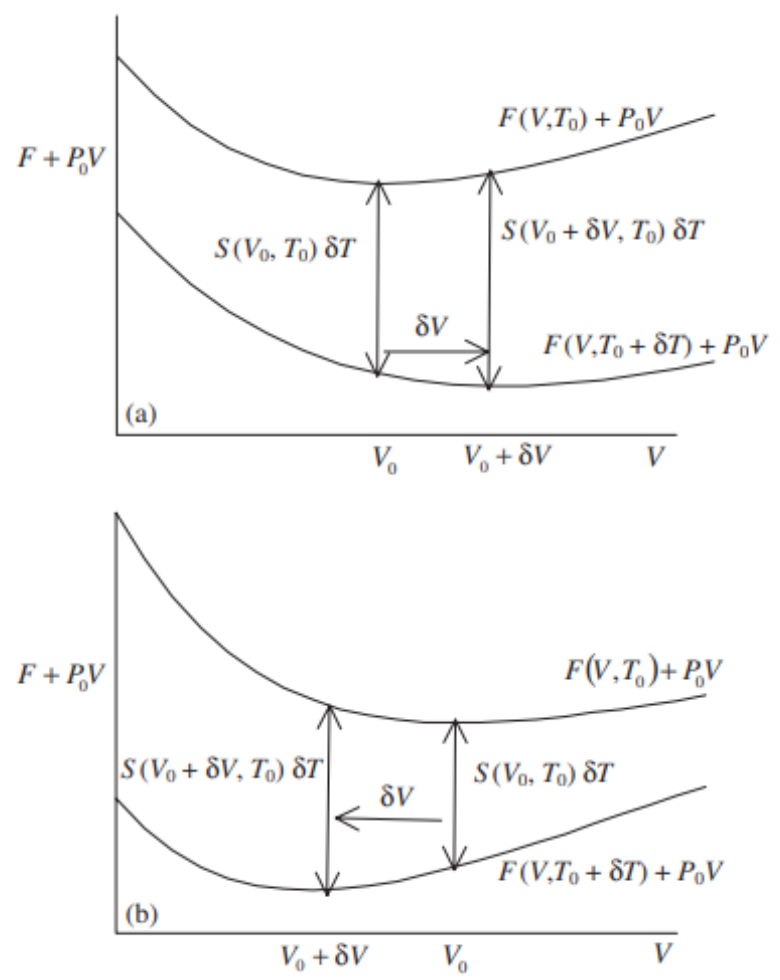

Figure 3- Graphical representation of the thermodynamics of thermal expansion. The figures show thermodynamic principles behind (a) positive thermal expansion and (b) negative thermal expansion response with increase of temperature [5]. The volumes indicated on the $x$-axis show the minima of the expression $F+P_{o} V$ versus $V$ isotherm. These are the equilibrium volumes at temperatures $T$ and $T+\delta T$, respectively.

Equation 4: Maxwell's relationships for $\boldsymbol{\alpha}_{v}$

$$
\alpha_{v}=\frac{1}{V}\left(\frac{\partial V}{\partial T}\right)_{P}=-\frac{1}{V}\left(\frac{\partial S}{\partial P}\right)_{T}=K_{T}\left(\frac{\partial S}{\partial V}\right)_{T}
$$

$\boldsymbol{\partial S}=$ entropy variation

$\boldsymbol{S}=$ entropy

$\boldsymbol{P}=$ pressure 
Equation 5: Relationship between $K_{T}$ and $\boldsymbol{\alpha}_{\boldsymbol{v}}$

$$
K_{T}=-\frac{1}{V}\left(\frac{\partial \mathrm{V}}{\partial P}\right)_{T}
$$

There is a select class of materials with the ability to present negative thermal expansion, i.e., thermomiotic ceramics. These materials are ceramic oxides that are part of advanced ceramics and besides a negative thermal expansion (NTE) some of them almost do not change their dimensions with increasing temperature, showing near-zero thermal expansion (NZTE). When $\alpha$ takes negative values, the entropy increases when the material is compressed in an isothermal way [4]. Materials with NTE present negative $\alpha_{1}$ values in some temperature range. This value can be between $-11 \times 10^{-6}{ }^{\circ} \mathrm{C}^{-1}$ to $-0.11 \times 10^{-6}{ }^{\circ} \mathrm{C}^{-1}$ [6].

The NTE in a material is an anomalous event since, in general, the materials tend to present positive thermal expansion (PTE). This behavior cannot be explained solely from the potential energy well, since it involves other types of interatomic movements and interactions such as transverse vibrations, nonvibrational mechanisms or phase transitions [1] [3] [5].

\subsection{1. Dynamic and structural mechanisms of NTE}

All materials are composed of the union of a series of atoms which are connected by chemical bonds of different types. These bonds can present alterations when a material is heated (or cooled) generating "chain movements". When the temperature increases, an elongation process occurs between some of the bonds which are related to the anharmonicity present in the interatomic potential energy well and can be represented schematically as shown in Figure 4-A. On the other hand, atomic motions can be also transverse to the direction in which the chain is oriented. These movements tend to reduce the length of the bonds causing NTE [5] [7].

In a crystalline material the lattice vibrations are quantized by phonons. Phonons are classified into: optical (short wavelengths and high frequencies and energy), acoustic (long wavelengths and low frequencies and energy), transverse optical (wich can only be excited at high temperatures due to its high energies) and 
acoustic transverse (its excitation occurs at lower temperature levels) [1] [3] [5] [7]. These movements are described in a general way in Figure 4.

A

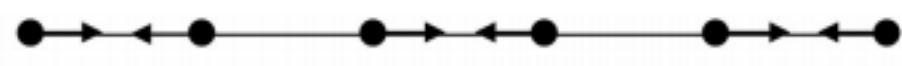

B

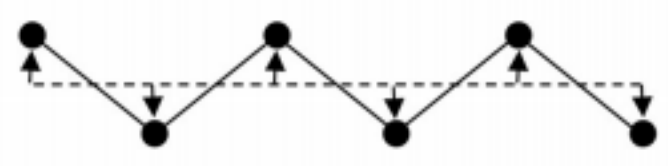

C

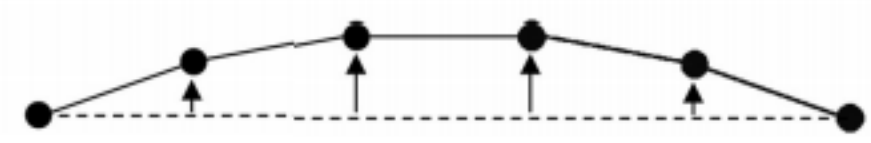

Figure 4- Schematic representation of lattice modes for a chain of atoms. (a) Longitudinal optical, (b) high-energy transverse optical and (c) low-energy transverse acoustic [7].

\subsection{2.}

\section{Structural vibrations}

Lattice vibrations are to a greater extent responsible for the thermal expansion of a material, except for some materials at very low temperatures [5] [7]. These vibrations are quantized through a phonon which can have different ranges of wavelengths, amplitude and frequency [3]. If the lattice waves are along the direction of propagation longitudinal phonons will emerge, when contrary transverse phonons will be formed [1].

The thermomiotics materials have strong chemical bonds. Figure 5 show a schematic representation for the longitudinal and transverse vibrations in M-O-M type bonds. In it, it is possible to perceive how, in the event of an increase in temperature, the bonds vibrate longitudinally and transversely, generating an increase or reduction in interatomic distances[1] [2] [7].

The negative thermal expansion is favored when vibrational outweigh longitudinal contribution. Additionally, the prevalence of open crystal structures and low coordination numbers (maximum 3) are favorable for this behavior. The open crystal structure facilitates the presence of transverse vibrations between the 
atoms with coordination number 2 . These atoms link tetrahedra and octahedra in a open framework, connected through the vertices [2] [7].

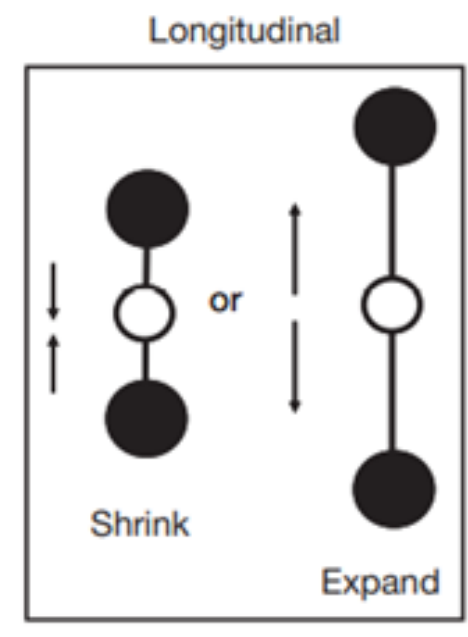

(a)

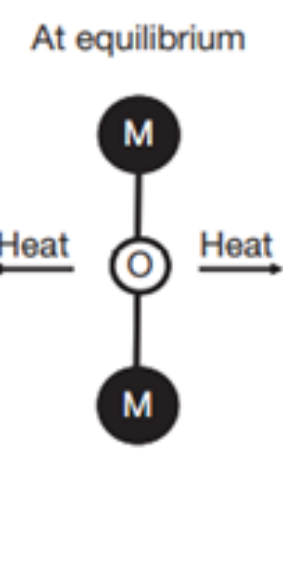

(b)
Transverse

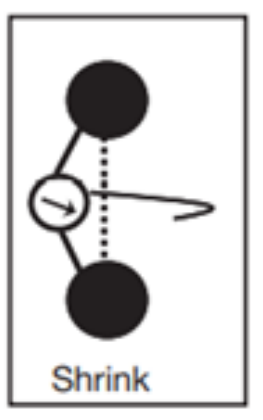

(c)

Figure 5- Schematic representations of (a) longitudinal vibrations (the average distance between the atoms increases due to the anharmonicity of the potential energy curve and changes in temperature), middle-system in equilibrium and (c) transverse vibrations (reduction of the mean distance between atoms, as a consequence negative thermal expansion can be is generated) [1].

Some thermomiotic ceramics that have NTEs are built from tetrahedral and octahedral unitawith strong A-O and M-O type bonds, joined at corners by 2coordinated linkers (the most common linker is oxygen anion). These bonds are of great importance for the existence of predominant transverse vibration and the existence of NTE. The rigid unit mode model considers these facts; the tetrahedral and octahedral structures are considered rigid in a many thermomiotic families. However, they present rotation among themselves [1] [2] [8]. Figure 6 shows a schematic bidimensional representation of a series of connected polyhedral sharing their corners and changing their dimensions (contraction) due to increase of temperature, leading to NTE.

A technique to show the apparent length bond contraction between the M$\mathrm{O}$ bond with respect to changes in temperature is High Temperature X-ray Power Diffraction (HT-XRPD or In Situ XRPD). In Figure 1 the anharmonic potential energy curve was presented and indicates that all bonds tend to expand when there 
is an increase in temperature, however, it occurs at different speeds, due to the strength or weakness of the different bonds. Stronger bonds expand slower than weak bonds. This effect is attributed to libration [3].

Libration is an acoustic transverse mode attributed to a particular vibration where the movement of the 2-coordinated linker atom occurs in a specific direction relative to the $\mathrm{M}-\mathrm{O}$ bond. When a material with libration vibrations is analyzed using HT-XRPD, the technique perceives the reduction of the perceived length in the M-O bond [1] [3]. Figure 7 shows a schematic representation of libration.
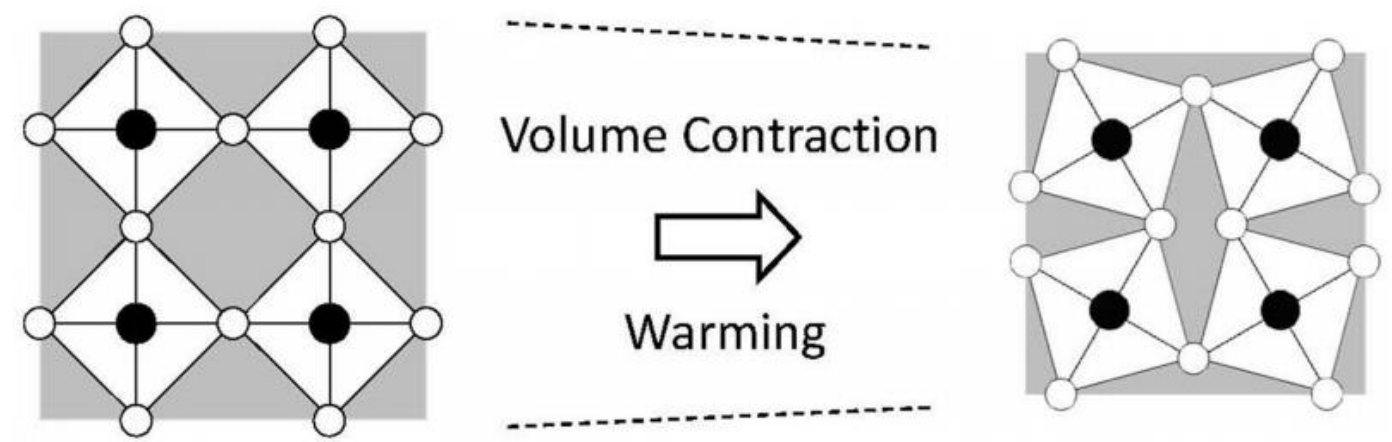

Figure 6- Schematic representation of dimensional contraction caused by increase in the temperature of a thermomiotic material and its mechanism of rotation between polyhedra [9]. White spheres represent oxygens with coordination number 2 and black spheres represents metallic cations with coordination number 4 or 6.

Finally, it is important to mention that the vibrational effects on thermal expansion can be evaluated using the quasi-harmonic approach [5]. The dependence between the volume and the vibrational frequencies of the network can be studied from anharmonicity, a feature directly related to the thermal expansion of a material. Anharmonicity can be quantified using the Grüneisen parameter, represented by Greek letter $\gamma$ and defined by equation 6 , where $V$ is volume, $K$ is a bulk modulus and $C_{v}$ is specific heat capacity [1] [3] [5] [8]. 


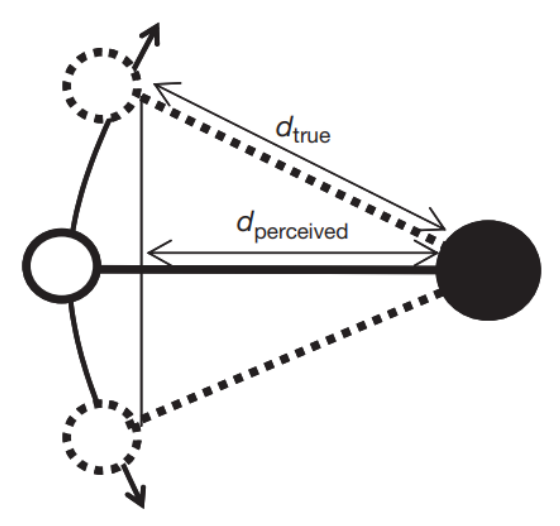

Figure 7- Schematic representation of libration [1]. It is possible to distinguish the true distance and the perceived distance when this phenomenon occurs in $\mathrm{M}-\mathrm{O}$ bonds. The libration cause a reduction of perceived length when the magnitude of the vibration increases.

Equation 6: Grüneisen parameter

$$
\gamma=\frac{\alpha_{v} V K}{C_{v}}
$$

The Grüneisen parameter evaluated for crystalline solid indicates the stage of anharmonic behavior of the phonons at certain temperature. Negative values of this parameter will result in NTE, while near-zero values of Grüneisen parameter would be responsible for NZTE [3] [10].

\subsection{3.}

\section{Families of thermomiotic materials}

Thermomiotic ceramics have generated special interest because they have the ability to adjust some of its properties such as the CTE. This is particularly favorable when a material resistant to thermal shock is desired because the thermal stresses are reduced and the possibility of rupture due to high variations in temperature is minimized [11].

Within thermomiotic ceramics there are different types of families that present NTE or NZTE. Among them: $\mathrm{AM}_{2} \mathrm{O}_{8}$ [12], $\mathrm{AM}_{2} \mathrm{O}_{7}$ [13] [14], $\mathrm{A}_{2} \mathrm{M}_{4} \mathrm{O}_{15}$ [15], $\mathrm{AMO}_{5}$ [16], $\mathrm{AO}_{3}$ [17] and $\mathrm{A}_{2} \mathrm{M}_{3} \mathrm{O}_{12}$ [1]. 


\subsection{4.}

\section{$\mathrm{A}_{2} \mathrm{M}_{3} \mathrm{O}_{12}$ familiy}

In the $\mathrm{A}_{2} \mathrm{M}_{3} \mathrm{O}_{12}$ family the constituent $A^{3+}$ can be rare earth or transition cation $\left(\mathrm{Al}^{3+}, \mathrm{Cr}^{3+}, \mathrm{In}^{3+}, \mathrm{Fe}^{3+}, \mathrm{Sc}^{3+}, \mathrm{Y}^{3+}, \mathrm{Lu}^{3+}, \mathrm{Ho}^{3+}, \mathrm{Er}^{3+}, \mathrm{Tm}^{3+}, \mathrm{Ga}^{3+}, \mathrm{Yb}^{3+}\right)$ while the constituent $M^{6+}$ can be hexavalent cation $\left(\mathrm{W}^{6+}\right.$ or $\left.\mathrm{Mo}^{6+}\right)$. These constituents offer a wide range of compositions due to structural flexibility [1] [3] [6]. This is particularly interesting since it opens the possibility of changing the cations and as a consequence generate variations in the thermal behavior of the material. However, in this family of metal oxides there is a limitation with respect to cation $A^{3+}$ which must have a preference for adopting an octahedral position [3]. Liu H. et al. [6] affirm that half of the materials in the $\mathrm{A}_{2} \mathrm{M}_{3} \mathrm{O}_{12}$ family have NTE properties.

\subsection{5.}

\section{$\mathrm{A}_{2} \mathrm{M}_{3} \mathrm{O}_{12}$ structure}

In $\mathrm{A}_{2} \mathrm{M}_{3} \mathrm{O}_{12}$ family, the structure adopted is given by $\mathrm{AO}_{6}$ octahedra and $\mathrm{MO}_{4}$ tetrahedra. The $\mathrm{AO}_{6}$ octahedra share the vertices with $\mathrm{MO}_{4}$ tetrahedra. Such a corner sharing leads to A-O-M linkages. In the process of crystallization, the materials of the $\mathrm{A}_{2} \mathrm{M}_{3} \mathrm{O}_{12}$ family can adopt monoclinic or orthorhombic structures. The monoclinic structure is denser and presents PTE. In the orthorhombic structure the density decreases, generating materials with NZTE or NTE. This condition is of great importance when a material with high resistance to thermal shock is required in specific applications in fields such as communications, microelectronics and aerospace industry [1] [6] [18].

These structural arrangements contribute to the level of rigidity presented in the material's structure. The rigidity is given by repulsion effects between anions, in this case $\mathrm{O}-\mathrm{O}$, which are stronger as the polyhedra are smaller because the O-O distance will be smaller. On the other hand, the rigidity is also related to the size of the cation $A^{3+}$, a bigger cation will increase the capacity to deform of the $\mathrm{AO}_{6}$ octahedra, and its rigidity will decrease favoring the presence of NTE and NZTE behavior [1] [3]. This can be confirmed through studies such as the one carried out by Woodcock, et al. [21]. In this investigation, the authors reported the influence that the change in the size of cation $A^{3+}$ had over coefficients of thermal expansion. Larger $A^{3+}$ caused higher negative CTE. 
Liu H. et al. [6] reported that $\mathrm{A}_{2} \mathrm{M}_{3} \mathrm{O}_{12}$ tungstates and molybdates with $A^{3+}$ site occupied by trivalent cations such as: $\mathrm{Y}^{3+}, \mathrm{Ho}^{3+}, \mathrm{Tm}^{3+}, \mathrm{Yb}^{3+}, \mathrm{In}^{3+}, \mathrm{Fe}^{3+}, \mathrm{Cr}^{3+}$, $\mathrm{Ga}^{3+}$ or $\mathrm{Al}^{3+}$, present NTE and generate structures similar to that of $\mathrm{Sc}_{2} \mathrm{~W}_{3} \mathrm{O}_{12}$ (Figure 8).

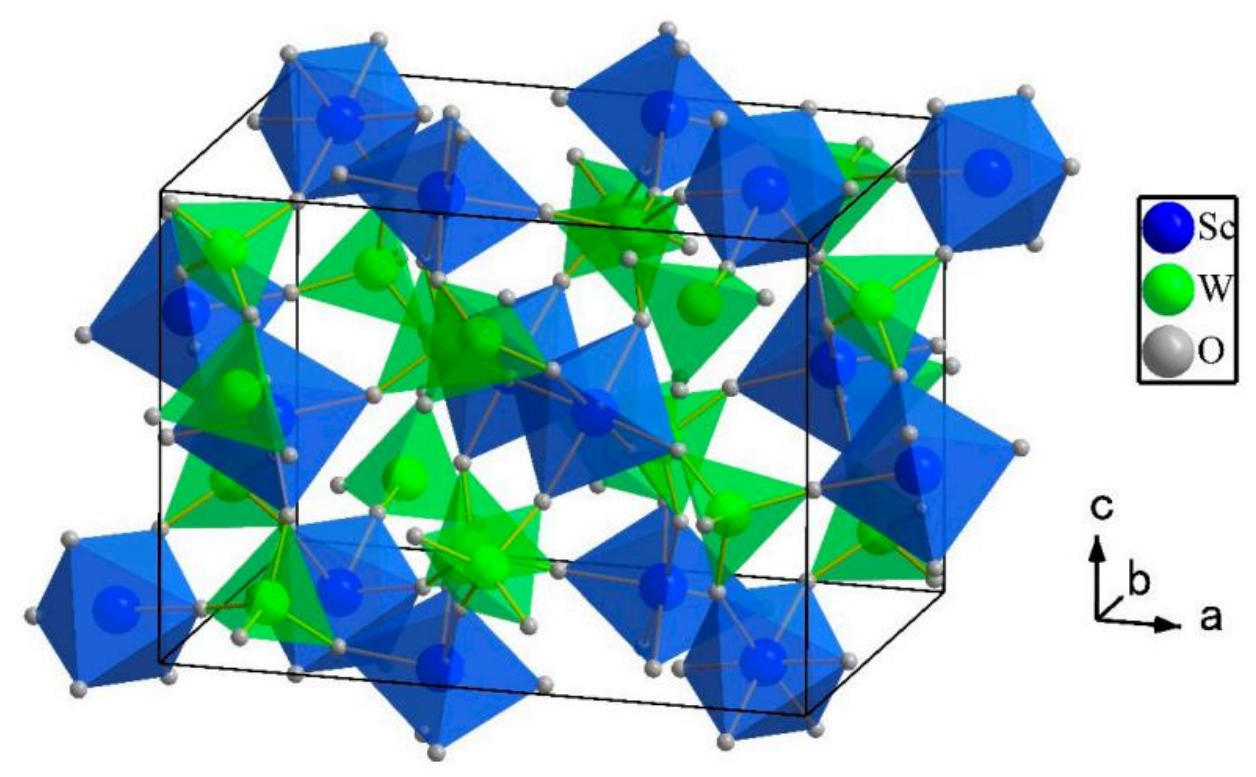

Figure 8- Representation of $\mathrm{Sc}_{2} \mathrm{~W}_{3} \mathrm{O}_{12}$ crystal structure. It is possible to observe $\mathrm{ScO}_{6}$ octahedral units (blue) connected through vertices with $\mathrm{WO}_{4}$ tetrahedral (green) [6].

\subsection{6.}

\section{$A_{2-x} B_{x} M_{3} O_{12}$ : a solid solutions in $A_{2} M_{3} O_{12}$ familiy}

In the $\mathrm{A}_{2} \mathrm{M}_{3} \mathrm{O}_{12}$ family $A^{3+}$ can be occupied by different trivalent cations. However, member $A^{3+}$ can be partially substituted by another trivalent cation. This behavior favors the orthorhombic phase and therefore the NTE when the substitution atoms present higher atomic radius and lower electronegativity.

The $\mathrm{A}_{2} \mathrm{M}_{3} \mathrm{O}_{12}$ family has shown adaptability of member $A^{3+}$, which may have more than one trivalent cation, making possible the existence of an $\mathrm{A}_{2-}$ ${ }_{\mathrm{x}} \mathrm{B}_{\mathrm{x}} \mathrm{W}_{3} \mathrm{O}_{12}$ solid solutions where $B^{3+}$ is a new trivalent cation different from $A^{3+}$. These types of compounds have been reported in studies for materials such as $\mathrm{AlInW}_{3} \mathrm{O}_{12}, \quad \mathrm{Al}_{1.68} \mathrm{Sc}_{0.02} \mathrm{In}_{0.3} \mathrm{~W}_{3} \mathrm{O}_{12}, \quad \mathrm{ScInW}_{3} \mathrm{O}_{12}, \quad \mathrm{ScAlW}_{3} \mathrm{O}_{12}, \quad \mathrm{ErInW}_{3} \mathrm{O}_{12}$, $\mathrm{HoScW}_{3} \mathrm{O}_{12}, \mathrm{ScGaW}_{3} \mathrm{O}_{12}, \mathrm{YAlW}_{3} \mathrm{O}_{12}$ [19], $\mathrm{HfMgW}_{3} \mathrm{O}_{12}$ [20], $\mathrm{MgZrW}_{3} \mathrm{O}_{12}$ [21], $\mathrm{Yb}_{2-\mathrm{x}} \mathrm{Ga}_{\mathrm{x}} \mathrm{W}_{3} \mathrm{O}_{12}$ [22], $\mathrm{Al}_{2-\mathrm{x}} \mathrm{Sc}_{\mathrm{x}} \mathrm{W}_{3} \mathrm{O}_{12}$ [23], $\mathrm{In}_{2-\mathrm{x}} \mathrm{Sc}_{\mathrm{x}} \mathrm{W}_{3} \mathrm{O}_{12}$ [24], $\mathrm{In}_{2-\mathrm{x}} \mathrm{Sc}_{\mathrm{x}} \mathrm{Mo}_{3} \mathrm{O}_{12}$ [25], $\mathrm{Y}_{2-\mathrm{x}} \mathrm{Sm}_{\mathrm{x}} \mathrm{W}_{3} \mathrm{O}_{12}$ [26], $\mathrm{Fe}_{2-\mathrm{x}} \mathrm{Sc}_{\mathrm{x}} \mathrm{Mo}_{3} \mathrm{O}_{12}$ [27], $\mathrm{Fe}_{2-\mathrm{x}} \mathrm{Y}_{\mathrm{x}} \mathrm{Mo}_{3} \mathrm{O}_{12}$ [28], $\mathrm{Cr}_{2 \mathrm{x}} \mathrm{Fe}_{2-2 \mathrm{x}} \mathrm{Mo}_{3} \mathrm{O}_{12}$, 
$\mathrm{Al}_{2 \mathrm{x}} \mathrm{Fe}_{2-2 \mathrm{x}} \mathrm{Mo}_{3} \mathrm{O}_{12}, \mathrm{Al}_{2 \mathrm{x}} \mathrm{Cr}_{2-2 \mathrm{x}} \mathrm{Mo}_{3} \mathrm{O}_{12}$ [29], $\mathrm{Al}_{2-\mathrm{x}} \mathrm{Me}_{\mathrm{x}} \mathrm{W}_{3} \mathrm{O}_{12}$ (Me=Sc, In) [30], $\mathrm{Y}_{2-}$ ${ }_{x} \mathrm{Ce}_{\mathrm{x}} \mathrm{W}_{3} \mathrm{O}_{12}$ [31], $\mathrm{Cn}_{1-\mathrm{x}} \mathrm{Zn}_{\mathrm{x}} \mathrm{WO}_{4}$ [32], among others [6] [18].

\subsection{7.}

\section{$\mathrm{A}_{2} \mathrm{M}_{3} \mathrm{O}_{12}$ anisotropic, intrinsic and extrinsic thermal expansion}

Thermomiotic ceramics of the $\mathrm{A}_{2} \mathrm{M}_{3} \mathrm{O}_{12}$ family exhibit anisotropic behavior, therefore, thermal expansion process will be different along the crystallographic axes.

When the intrinsic-thermal expansion (free of any microstructural effect) in an anisotropic material is being characterized using techniques such as HT-XRPD, the CTE values along the 3 crystallographic axes are different. For example, the CTE can be positive along one of the axes and negative over the other two.

On the other hand, it is possible to characterize the extrinsic thermal expansion of a material. In this case, the CTE is obtained by dilatometry. This extrinsic thermal expansion accounts for two contributions: intrinsic and microstructural defects.

However, the intrinsic CTE and the extrinsic CTE do not present the same values. This type of behavior is evident in the study carried out by Evans et al. [18]. In it, the authors report the difference between the intrinsic CTE and extrinsic CTE values (Table1). This difference is mainly attributed to the presence of microcracks in the microstructure of a bulk material.

Table 1- Coefficient of thermal expansion $\boldsymbol{\alpha}_{\boldsymbol{i}}$ (intrinsic) and $\boldsymbol{\alpha}_{\boldsymbol{e}}$ (extrinsic) in some compounds within $\mathrm{A}_{2} \mathrm{M}_{3} \mathrm{O}_{12}$ family [18].

\begin{tabular}{ccc}
\hline Compound & $\boldsymbol{\alpha}_{\boldsymbol{e}}\left(\times \mathbf{1 0}^{\mathbf{- 6}} \mathbf{0}^{-\mathbf{1}}\right)$ & $\boldsymbol{\alpha}_{\boldsymbol{i}}\left(\times \mathbf{1 0}^{-\mathbf{6}} \mathbf{C}^{\mathbf{- 1}}\right)$ \\
\hline $\mathrm{Sc}_{2} \mathrm{~W}_{3} \mathrm{O}_{12}$ & -11 & -2.2 \\
\hline $\mathrm{Sc}_{2} \mathrm{Mo}_{3} \mathrm{O}_{12}$ & -5 & -1.1 \\
\hline $\mathrm{Al}_{2} \mathrm{~W}_{3} \mathrm{O}_{12}$ & -3 & +2.2 \\
\hline $\mathrm{Al}_{1.6} \mathrm{In}_{0.4} \mathrm{~W}_{3} \mathrm{O}_{12}$ & +1.5 & +1.6
\end{tabular}




\subsection{8. \\ Phase transitions in $\mathrm{A}_{2} \mathrm{M}_{3} \mathrm{O}_{12}$ family}

In section 2.2.5. it was mentioned that the $\mathrm{A}_{2} \mathrm{M}_{3} \mathrm{O}_{12}$ family can adopt monoclinic or orthorhombic structures. This characteristic is of great importance because the thermal expansion of these materials is associated with the type of structure they adopt. At lower temperatures the crystal is associated with monoclinic phase with $P 2_{1} / a$ space group. As the temperature increase, the structure tends to transform into the orthorhombic one with Pnca space group, however, preserving connectivity in both structures with $\mathrm{AO}_{6}$ octahedra sharing vertices with $\mathrm{MO}_{4}$ tetrahedra. This type of transition occurs at different temperatures depending on the nature of the material, most precisely on electronegativity of $A^{3+}$ [1] [6] [33].

The phase transition from monoclinic to orthorhombic is associated with the breaking of secondary $\mathrm{O}-\mathrm{O}$ bonds. As a consequence, a larger voids are formed in the orthorhombic phase. The orthorhombic phase, being less dense than the monoclinic, makes the NTE possible [18] [34].

In the $\mathrm{A}_{2} \mathrm{M}_{3} \mathrm{O}_{12}$ family, the electronegativity of cation $A^{3+}$ is related to the phenomenon of monoclinic and orthorhombic phase transitions. The higher electronegativity of member $A^{3+}$, the higher will be the phase transition temperature. It should be noted that the negative effective charge of oxygen decreases higher the electronegativity of cation $A^{3+}$. This facilitates the formation of secondary bonds and increases the phase transition temperature. Member $M^{6+}$ also generates changes in the phase transition temperature due to the electronegativity that this member can possess $\left(\mathrm{Mo}^{6+}-1.8\right.$ and $\left.\mathrm{W}^{6+}-1.7\right)$ [6] [18]. If member $A^{3+}$ is considered to be the same for molybdate and for tungstate, the phase transition temperatures will be higher in the $\mathrm{A}_{2} \mathrm{Mo}_{3} \mathrm{O}_{12}$ system than in the $\mathrm{A}_{2} \mathrm{~W}_{3} \mathrm{O}_{12}$ system [18]. The orthorhombic phases of some members of the $\mathrm{A}_{2} \mathrm{M}_{3} \mathrm{O}_{12}$ family, with member $A^{3+}$ occupied by some rare earth (lower electronegativity), are thermodynamically stable at temperatures close to room temperature (RT) [2].

This behavior can be evidenced in Figure 9. This Figure shows some molybdates and tungstates of the $\mathrm{A}_{2} \mathrm{M}_{3} \mathrm{O}_{12}$ family and the relationship that exists between the electronegativity of the $A^{3+}$ member and the phase transition temperature from monoclinic to orthorhombic structure. 

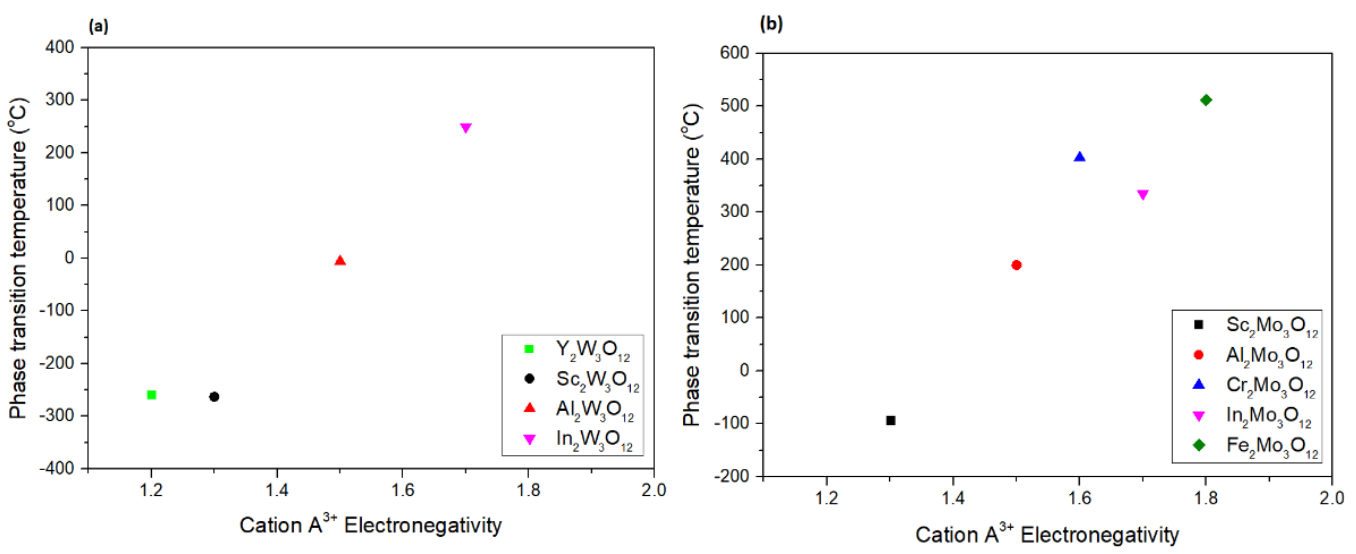

Figure 9- Phase transition temperature from monoclinic to orthorhombic structure of some compounds of the $\mathrm{A}_{2} \mathrm{M}_{3} \mathrm{O}_{12}$ family. (a) tungstates and (b) molybdates [6].

\subsection{9.}

\section{Effect of partial substitution of cation $A^{3+}$ on CTE in $\mathrm{A}_{2} \mathrm{M}_{3} \mathrm{O}_{12}$ family}

Transverse vibrations outweighting longitudinal vibrations cause the NTE phenomenon. These vibrations generate distortion in the polyhedra, mainly the octahedra $\mathrm{AO}_{6}$. The greater the cationic radius of the $A^{3+}$ cation great distortion, which favors the existence of NTE. The cationic radius size of the $A^{3+}$ and $M^{6+}$ members are closely related to distortion in polyhedra. Larger cationic radii generate greater distortion. This behavior is evidenced in Figure 10. It shows a series of compounds that are part of the $\mathrm{A}_{2} \mathrm{M}_{3} \mathrm{O}_{12}$ family and the influence that cations $A^{3+}$ and $M^{6+}$ have on the polyhedral distortion $\mathrm{AO}_{6}$ and the variation in the CTE value.

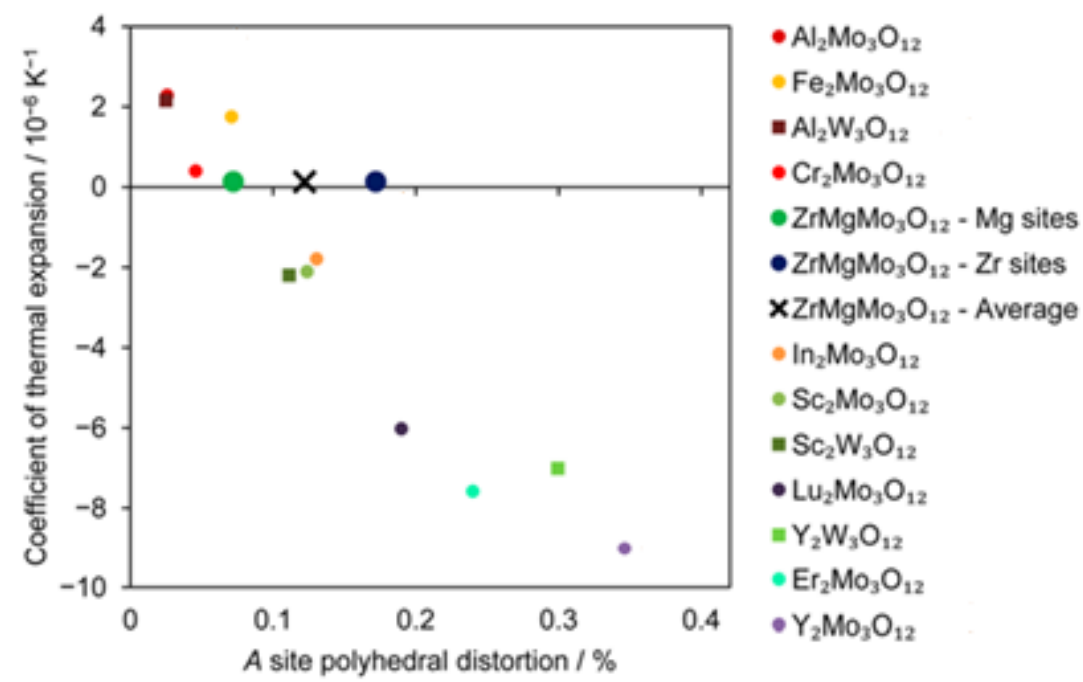

Figure 10- CTE as a function of $A$ site polyhedral distortion [35]. 
Some studies report the effect of partial substitution of the $A^{3+}$ cation for the $\mathrm{A}_{2-\mathrm{x}} \mathrm{B}_{\mathrm{X}} \mathrm{M}_{3} \mathrm{O}_{12}$ solid solutions $\left(A^{3+}, B^{3+}\right.$ are trivalent cations and $M^{6+}$ can be $\mathrm{W}^{6+}$ or $\mathrm{Mo}^{6+}$ ) on CTE and others properties (some compounds mentioned in section 2.2.6).

For example, Liu H. et al. [31], reports the linear CTEs for $\mathrm{Y}_{2-\mathrm{x}} \mathrm{Ce}_{\mathrm{x}} \mathrm{W}_{3} \mathrm{O}_{12}$ obtained by dilatometry. The ionic radius of $\mathrm{Y}^{3+}$ is equal to $0.93 \AA$ and that of $\mathrm{Ce}^{3+}$ is equal to $1.01 \AA$, and the partial substitution of $\mathrm{Y}^{3+}$ for $\mathrm{Ce}^{3+}$ causes changes in the linear CTEs in this solud solution. Table 2.

Table 2- Linear coefficients of thermal expansion in $\mathrm{Y}_{2-\mathrm{x}} \mathrm{Ce}_{\mathrm{x}} \mathrm{W}_{3} \mathrm{O}_{12}$ [31].

\begin{tabular}{cc}
\hline $\mathbf{Y}_{2-\mathrm{x}} \mathbf{C e}_{\mathbf{x}} \mathbf{W}_{\mathbf{3}} \mathbf{O}_{\mathbf{1 2}}$ & $\boldsymbol{\alpha}_{\boldsymbol{l}}\left(\mathbf{x}^{\mathbf{1 0}}{ }^{\circ} \mathbf{C}^{-\mathbf{1}}\right)$ \\
\hline $\mathrm{x}=0.00$ & -13.094 \\
\hline $\mathrm{x}=0.25$ & -11.399 \\
\hline $\mathrm{x}=0.50$ & -9.59. \\
\hline $\mathrm{x}=1.00$ & -3.758 \\
\hline $\mathrm{x}=1.50$ & -1.787 \\
\hline $\mathrm{x}=1.75$ & -0.820 \\
\hline $\mathrm{x}=2.00$ & 2.927
\end{tabular}

Another example of the influence of partial substitution of cation $A^{3+}$ on CTE was reported by Dasgupta et al. [23]. In this study, a partial substitution of aluminum (ionic radius $0.535 \AA$ ) by scandium (ionic radius $0.745 \AA$ ) was carried out, and the authors reports the value of the coefficients of thermal expansion. The results are shown in Table 3.

Table 3- Linear coefficients of thermal expansion in $\mathrm{Al}_{2-x} \mathrm{Sc}_{x} \mathrm{~W}_{3} \mathrm{O}_{12}$ [23].

\begin{tabular}{cc}
\hline $\mathbf{A l}_{2-\mathbf{x}} \mathbf{S c}_{\mathbf{x}} \mathbf{W}_{\mathbf{3}} \mathbf{O}_{\mathbf{1 2}}$ & $\boldsymbol{\alpha}_{\boldsymbol{l}}\left(\mathbf{x}^{\mathbf{1 6}}{ }^{\circ} \mathbf{C}^{-\mathbf{1}}\right)$ \\
\hline $\mathrm{x}=0.1$ & 2.171 \\
\hline $\mathrm{x}=0.4$ & 1.779 \\
$\mathrm{x}=0.8$ & 1.546 \\
\hline $\mathrm{x}=1.2$ & 0.818 \\
\hline $\mathrm{x}=1.5$ & -0.15 \\
$\mathrm{x}=1.7$ & -0.820 \\
\hline
\end{tabular}




\subsubsection{0. \\ Hygroscopicity}

Hygroscopicity is a physicochemical property of materials which measures the level of interaction between a material and the water molecules present in the surrounding atmosphere. This property describes the ability of materials to absorb or adsorb moisture from the environment to which a material is subjected [36]. Hygroscopicity can appear in materials due to the presence of microchannels which facilitate the entry of water molecules. The control of this property is of great interest in the development of thermomiotic materials because they alter properties such as thermal expansion.

The size of the ionic radius of the member $A^{3+}$ is one of the factors that most affects the presence of hygroscopicity. For example, in compounds of the $\mathrm{A}_{2} \mathrm{M}_{3} \mathrm{O}_{12}$ family where the $A^{3+}$ member is occupied by $\mathrm{Ho}^{3+}, \mathrm{Y}^{3+}, \mathrm{Yb}^{3+}$ and $\mathrm{Lu}^{3+}$ present high NTE when they adopt orthorhombic structures, however the large size of the ionic radius favors the formation of large microchannels and therefore, the existence of water in these phases [6] [31] [37].

In order to reduce the level of hygroscopicity, trying to maintain NTE or NZTE in thermomiotic ceramics, the $\mathrm{A}_{2-\mathrm{x}} \mathrm{B}_{\mathrm{x}} \mathrm{M}_{3} \mathrm{O}_{12}$ solid solutions generate interest due to the possibility of partially replacing the $A^{3+}$ member in the $\mathrm{A}_{2} \mathrm{M}_{3} \mathrm{O}_{12}$ family.

Machado et al. [22] studied the $\mathrm{Yb}_{2-\mathrm{x}} \mathrm{Ga}_{\mathrm{x}} \mathrm{W}_{3} \mathrm{O}_{12}$ system. The partial substitution of $\mathrm{Yb}^{3+}$ for $\mathrm{Ga}^{3+}$ showed favorable results in reducing the hygroscopicity of this material, maintaining NTE. Liu H. et al. [31] studied the $\mathrm{Y}_{2-}$ ${ }_{\mathrm{x}} \mathrm{Ce}_{\mathrm{x}} \mathrm{W}_{3} \mathrm{O}_{12}$ system. When partially replacing the $\mathrm{Y}^{3+}$ member with $\mathrm{Ce}^{3+}$ there was a decrease in the level of hygroscopicity, however when the content of $\mathrm{Ce}^{3+}$ increased, the CTE went from negative values (NTE) to values closer to zero (NZTE). Finally,Xiang et al. [26] studied the partial substitution of $\mathrm{Y}^{3+}$ by $\mathrm{Sm}^{3+}$. The hygroscopicity level was reduced and the CTE value did not vary considerably.

\section{3.}

\section{$\mathrm{Al}_{2-\mathrm{x}} \ln \mathrm{n}_{\mathrm{x}} \mathrm{W}_{3} \mathrm{O}_{12}$ system}

The $\mathrm{Al}_{2-\mathrm{x}} \mathrm{In}_{\mathrm{x}} \mathrm{W}_{3} \mathrm{O}_{12}$ system is part of the $\mathrm{A}_{2-\mathrm{x}} \mathrm{B}_{\mathrm{x}} \mathrm{W}_{3} \mathrm{O}_{12}$ solid solutions. In this material the $A^{3+}$ member is occupied by $\mathrm{Al}^{3+}$ and the $B^{3+}$ member is occupied by $\mathrm{In}^{3+}$. Some properties of $\mathrm{Al}_{2} \mathrm{~W}_{3} \mathrm{O}_{12}$ and $\mathrm{In}_{2} \mathrm{~W}_{3} \mathrm{O}_{12}$ are known, including CTE and 
the phase transition temperatures from monoclinic to orthorhombic structure [19] [33] [38] [39] [40] [41].

Woodcock et al. [39] evaluated the thermal expansion in $\mathrm{Al}_{2} \mathrm{~W}_{3} \mathrm{O}_{12}$ using HT-XRPD. The authors determined the lattice parameters at different temperatures concluding that $\mathrm{Al}_{2} \mathrm{~W}_{3} \mathrm{O}_{12}$ has a low positive linear thermal expansion calculated at $\boldsymbol{\alpha}_{\boldsymbol{l}}=1.50 \times 10^{-6}{ }^{\circ} \mathrm{C}^{-1}$. The $\mathrm{Al}_{2} \mathrm{~W}_{3} \mathrm{O}_{12}$ presents an orthorhombic structure at RT. A transition from a monoclinic structure to orthorhombic at $-6{ }^{\circ} \mathrm{C}$ is reported. The authors Prisco et al. [42] and Imanaka et al. [40] synthesized $\mathrm{Al}_{2} \mathrm{~W}_{3} \mathrm{O}_{12}$ and determined by dilatometry that the CTE value of the material is $\boldsymbol{\alpha}_{\boldsymbol{l}}=1.75 \times 10^{-6}{ }^{\circ} \mathrm{C}^{-}$ ${ }^{1}$ and $\alpha_{l}=1.17 \times 10^{-6}{ }^{\circ} \mathrm{C}^{-1}$ respectively. It is important to mention that in the study presented by Imanaka et al. [40] this value was obtained for a single crystal of $\mathrm{Al}_{2} \mathrm{~W}_{3} \mathrm{O}_{12}$ and for Prisco et al. [42] it was obtained from polycrystalline bulk.

Baiz et al. [33] synthesized $\mathrm{In}_{2} \mathrm{~W}_{3} \mathrm{O}_{12}$ in powder form. The authors studied the material using HT-XRPD between $50{ }^{\circ} \mathrm{C}$ and $600{ }^{\circ} \mathrm{C}$. The results showed that a phase transition from a monoclinic structure to orthorhombic structure occurs between $200{ }^{\circ} \mathrm{C}$ and $250{ }^{\circ} \mathrm{C}$. The linear CTE value was reported only for the orthorhombic structure with a value of $\alpha_{l}=3.1 \times 10^{-6}{ }^{\circ} \mathrm{C}^{-1}$. On the other hand, Liu et al. [24] synthesized $\mathrm{In}_{2} \mathrm{~W}_{3} \mathrm{O}_{12}$ and by dilatometry determined that the monoclinic CTE was as high as $\boldsymbol{\alpha}_{\boldsymbol{l}}=16.51 \times 10^{-6}{ }^{\circ} \mathrm{C}^{-1}$. When $\operatorname{In}_{2} \mathrm{~W}_{3} \mathrm{O}_{12}$ presents orthorhombic structure the CTE has a value of $\boldsymbol{\alpha}_{l}=-3.01 \times 10^{-6}{ }^{\circ} \mathrm{C}^{-1}$, as measured by dilatometry, and that the transition temperature between these two phases occurs at $248^{\circ} \mathrm{C}$. This value is in the range of temperatures $\left(200{ }^{\circ} \mathrm{C}-250{ }^{\circ} \mathrm{C}\right)$ reported by Sivasubramanian et al. [41]. Additionally, the CTE of monoclinic $\operatorname{In}_{2} \mathrm{~W}_{3} \mathrm{O}_{12}$ is $\boldsymbol{\alpha}_{\boldsymbol{l}}=20 \times 10^{-6}{ }^{\circ} \mathrm{C}^{-1}$ determined between $100{ }^{\circ} \mathrm{C}$ and $200{ }^{\circ} \mathrm{C}$. The orthorhombic phase of $\operatorname{In}_{2} \mathrm{~W}_{3} \mathrm{O}_{12}$ has an average value of $\boldsymbol{\alpha}_{\boldsymbol{l}}=-1.85 \times 10^{-6}{ }^{\circ} \mathrm{C}^{-1}$ determined between $250{ }^{\circ} \mathrm{C}$ and $427{ }^{\circ} \mathrm{C}$ range. These CTE values were obtained using dilatometry [41].

Mary and Sleight [19] synthesized 19 compounds of $\mathrm{A}_{2} \mathrm{M}_{3} \mathrm{O}_{12}$ family and evaluated the thermal expansion of these materials using dilatometry in the temperature range between $\mathrm{RT}$ and $800{ }^{\circ} \mathrm{C}$. Among the materials reported by the authors were: $\mathrm{Al}_{2} \mathrm{~W}_{3} \mathrm{O}_{12}, \mathrm{In}_{2} \mathrm{~W}_{3} \mathrm{O}_{12}$ and some compositions of the $\mathrm{Al}_{2-\mathrm{x}} \mathrm{In}_{\mathrm{x}} \mathrm{W}_{3} \mathrm{O}_{12}$ system with values of $x=0.2 ; 0.3 ; 0.4,0.5$ and 1 . Two of the compositions attracted special attention; $x=0.2$ and $x=1$. Their measurements indicated NTE for $x=0.2$ between $100{ }^{\circ} \mathrm{C}$ and $600{ }^{\circ} \mathrm{C}$ range and NZTE for the composition $\mathrm{x}=1$ between 25 
${ }^{\circ} \mathrm{C}$ and $800{ }^{\circ} \mathrm{C}$ range. The compositions $\mathrm{x}=0.3$; 0.4 and 0.5 show low positive thermal expansion between $100{ }^{\circ} \mathrm{C}$ and $600{ }^{\circ} \mathrm{C}$.

Koseva et al. [30] prepared $\mathrm{AlnW}_{3} \mathrm{O}_{12}$ highly dense ceramic for two different particle sizes $(20 \mathrm{~nm}$ and $90 \mathrm{~nm})$ and three different treatment times $(1 \mathrm{~h}$, $5 \mathrm{~h}$ and $10 \mathrm{~h}$ ) but reported two in their paper. The results obtained are shown in Table 4. Additionally, by using XRPD, the authors described that the material has orthorhombic structure at RT. Pellets density was presented as a relative value to the crystallographic one $\left(5.079\right.$ g.cm ${ }^{-3}$ for $\left.\mathrm{Al}_{2} \mathrm{~W}_{3} \mathrm{O}_{12}\right)$

Table 4- $\mathrm{AllnW}_{3} \mathrm{O}_{12}$ relative density reported by Koseva et al [30].

\begin{tabular}{ccc}
\hline Treatment time (h) & $\begin{array}{r}\text { Relative density (\%) } \\
\text { Particle size 20 }(\mathrm{nm})\end{array}$ & $\begin{array}{c}\text { Relative density (\%) } \\
\text { Particle size } 90(\mathrm{~nm})\end{array}$ \\
\hline 5 & 71.5 & 72.3 \\
\hline 10 & 76.9 & 78.1 \\
\hline
\end{tabular}

Tzvetkov et al. [43] prepared solid solutions of $\mathrm{Al}_{2-\mathrm{x}} \mathrm{In}_{\mathrm{x}} \mathrm{W}_{3} \mathrm{O}_{12}$ in the range 0 $\leq x \leq 1.4$. Based on the diffractograms obtained at RT, the authors affirmed that all phases studied present orthorhombic structure.

Koseva et al. [44] synthesized $\mathrm{Al}_{2-\mathrm{x}} \mathrm{In}_{\mathrm{x}} \mathrm{W}_{3} \mathrm{O}_{12}$ for values of $0 \leq x \leq 2$ using the co-precipitation method. Using XRPD the author concluded that compositions between $0 \leq x \leq 1.1$ have orthorhombic structure at RT and for compositions between $1.1<x \leq 2$ that they are monoclinic at RT. Additionally, they presented phase transition temperatures for 3 of compositions, $x=1.3\left(118^{\circ} \mathrm{C}\right), \mathrm{x}=1.5(181$ $\left.{ }^{\circ} \mathrm{C}\right)$ and $\mathrm{x}=2\left(254^{\circ} \mathrm{C}\right)$.

However, Mary and Sleight [19], Tzvetkov et al. [43], Koseva et al. [44] and Yordanova et al. [45] do not report in their studies the CTEs of the synthesized materials or the level of hygroscopicity they possess, while only Mary and Sleight [19] and Koseva et al. [44] presented phase transition temperatures, although they were obtained through different techniques.

From the above, it was possible to show that there are no rigorous and systematic studies of $\mathrm{Al}_{2-\mathrm{x}} \mathrm{In}_{\mathrm{x}} \mathrm{W}_{3} \mathrm{O}_{12}$ system, especially those in which the material is evaluated at different temperatures. There are also no reports on CTEs of different compositions (x values) and on phase transition temperatures. Finally, none of the reviewed studies show the level of hygroscopicity that $\mathrm{Al}_{2-\mathrm{x}} \mathrm{In}_{\mathrm{x}} \mathrm{W}_{3} \mathrm{O}_{12}$ can have. The 
foregoing generated interest and arised the possibility of investigating this material, seeking to fill some of the gaps found.

\section{4.}

\section{CTE and thermal shock resistance}

Thermal shock resistance is the ability of a solid material to withstand abrupt changes in temperature. This temperature gradient provokes thermal stresses which can lead to material failure, a condition that is undesirable in materials applications. An example is showed in Figure 11.

Resistance to thermal shock has a direct relationship with thermal expansion. Some modern technological devices are designed aiming that their variations in dimensions are small when they are exposed to changes in temperature [46].

NTE or NZTE can have a positive influence on resistance to thermal shock because thermal stresses decrease. Mathematically the resistance to thermal shock is defined by the equation 7. It is important to note that the lower CTE increases the resistance to thermal shock.

Equation 5: Thermal shock resistance

$$
R_{s}=\frac{k \sigma}{\left|\alpha_{v}\right| E}
$$

$\boldsymbol{R}_{\boldsymbol{S}}=$ thermal shock resistance

$\boldsymbol{k}=$ thermal conductivity

$\boldsymbol{\sigma}=$ stress mechanical strength

$\boldsymbol{E}=$ Young modulus

$\boldsymbol{\alpha}_{v}=$ volumetric coefficient of thermal expansion 


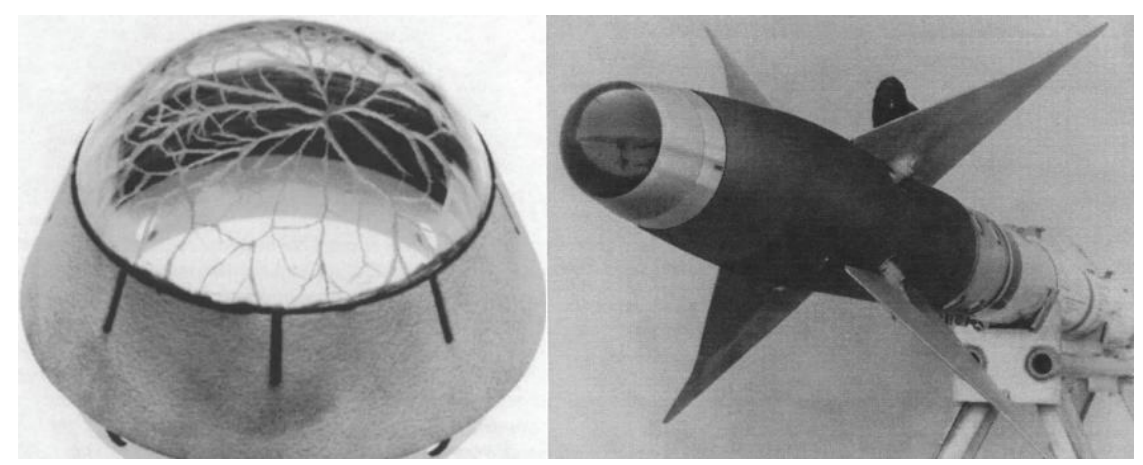

Figure 11- Fracture in the dome of a ballistic missile as a consequence of the thermal shock to which it was exposed as a result of a Mach 4.6 air flow [47].

\section{5 . \\ Synthesis of thermomiotic ceramics}

Within the existing techniques for the synthesis of ceramic materials, Marinkovic et al., [1] classifies them into two groups:

(1) High energy synthesis, such as solid state reactions (also known as ceramic method) and flux synthesis.

(2) Soft chemistry techniques: sol-gel method, hydrothermal routes and synthesis by co-precipitation. These techniques have aroused great interest due to their processing simplicity, higher phase homogeneity and, lower processing times and lower processing temperatures.

\subsection{1.}

\section{Co-precipitation method}

The co-precipitation is a technique that is simple in procedure and equipment needed and can be performed with low costs reactants. This method is used to obtain nanopowders by supersaturation of a solution. This process facilitates the formation of nucleos through homogeneous nucleation. This precipitates are generally amorphous, for this reason crystallization processes must be carried out by exposing the precipitate to higher temperatures. It is a suitable technique to obtain nanometric powders with particles between 15-50 nm. The material is chemically homogeneous and forms single-phase powders [1] [48] [49]. 


\subsection{2. \\ Conformation}

The conformation process consists of producing a green body using a press, a mold using the powder of the desired material. Binders are sometimes used to ensure a more uniform distribution when pressed. In this process, a solid is obtained whose density is between $40 \%$ and $60 \%$ of the theoretical density (TD) of the material. The green body is characterized by being highly porous and relatively brittle.

Once the green body is obtained, it is subjected to a sintering process at high temperatures in order to achieve densification of the material.

\subsection{3.}

\section{Sintering}

In the manufacture of ceramics, it is common to include a heat treatment in which the material obtained in powder form is converted into a solid and dense body. This process is known as sintering. In this process variables such as temperature, particle size, applied pressure and atmosphere are important due to the influence they have on the microstructure of the material [50]. For this process to occur, mass transfer is necessary.

In crystalline materials, sintering can occur by several mechanisms which are named in Figure 12. In this figure a schematic representation of the different transport paths of matter between two particles are presented.

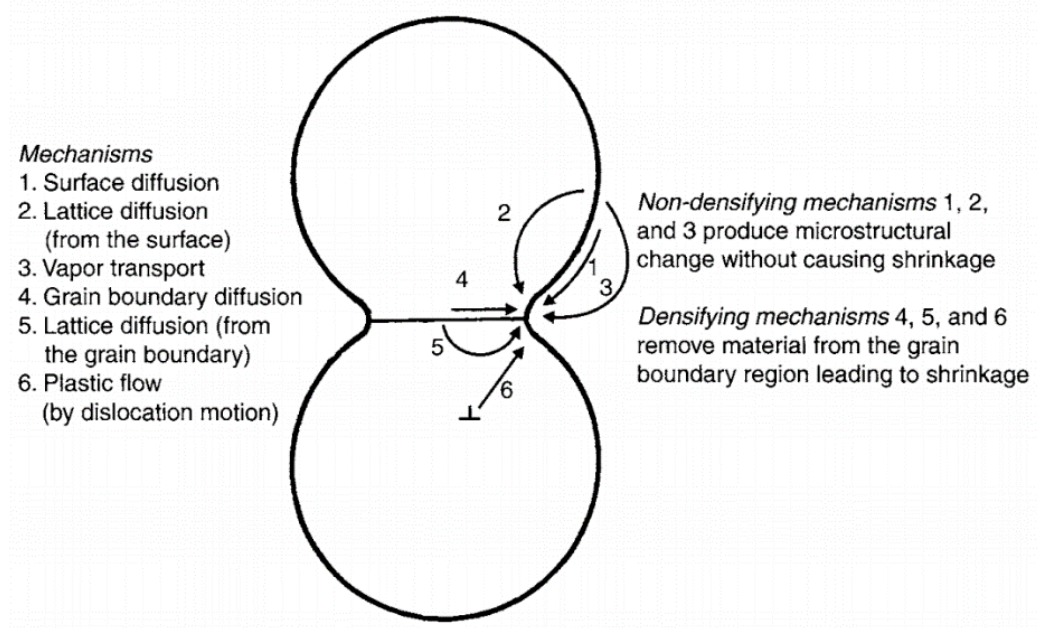

Figure 12- Schematic representation of sintering mechanisms for a two particles [50]. 


\section{3}

\section{Objectives}

\section{1.}

\section{General objective}

To study the extrinsic and intrinsic thermal expansion of $\mathrm{Al}_{2-\mathrm{x}} \operatorname{In}_{\mathrm{x}} \mathrm{W}_{3} \mathrm{O}_{12}$ system, its phase transitions and hygroscopicity.

\section{2.}

\section{Specific objectives}

1) Synthesis by the co-precipitation method of $\mathrm{Al}_{2-\mathrm{x}} \mathrm{In}_{\mathrm{x}} \mathrm{W}_{3} \mathrm{O}_{12}$ powders with values of $\mathrm{x}=0.2 ; 0.4,0.7$ and 1 .

2) Determination of the extrinsic and intrinsic coefficients of thermal expansion of $\mathrm{Al}_{2-\mathrm{x}} \mathrm{In}_{\mathrm{x}} \mathrm{W}_{3} \mathrm{O}_{12}$ for the synthesized compositions.

3) Study the existence of phase transitions within $\mathrm{Al}_{2-\mathrm{x}} \mathrm{In}_{\mathrm{x}} \mathrm{W}_{3} \mathrm{O}_{12}$ system.

4) Determination of the level of hygroscopicity inside $\mathrm{Al}_{2-\mathrm{x}} \mathrm{In}_{\mathrm{x}} \mathrm{W}_{3} \mathrm{O}_{12}$ system. 


\section{4 \\ Materials and methods}

\section{1.}

\section{Co-precipitation method for the $\mathrm{Al}_{2-\mathrm{x}} \mathrm{In}_{\mathrm{x}} \mathrm{W}_{3} \mathrm{O}_{12}$}

The synthesis of $\mathrm{Al}_{2-\mathrm{x}} \mathrm{In}_{\mathrm{x}} \mathrm{W}_{3} \mathrm{O}_{12}$ powders was made through the modified reversestrike co-precipitation method. The reagents used were $\mathrm{Al}\left(\mathrm{NO}_{3}\right)_{3} \cdot \mathrm{xH}_{2} \mathrm{O}$, $\mathrm{In}\left(\mathrm{NO}_{3}\right)_{3} \cdot x \mathrm{H}_{2} \mathrm{O}($ Alfa Aesar, purity $\geq 99 \%)$ and $\mathrm{Na}_{2} \mathrm{WO}_{4} \cdot 2 \mathrm{H}_{2} \mathrm{O}$ (Sigma Aldrich, St. Louis, MO, USA, purity $\geq 99 \%$ ).

Using this technique, $\mathrm{Al}_{2-\mathrm{x}} \mathrm{In}_{\mathrm{x}} \mathrm{W}_{3} \mathrm{O}_{12}$ precursor powders were obtained with nominal chemical compositions $\mathrm{x}=0.2,0.4,0.7$ and 1 . Simultaneous dropping of $0.1 \mathrm{M}$ aqueous stoichiometric solutions of $\mathrm{Al}\left(\mathrm{NO}_{3}\right)_{3} \cdot \mathrm{xH}_{2} \mathrm{O}$ and $\mathrm{In}\left(\mathrm{NO}_{3}\right)_{3} \cdot \mathrm{xH}_{2} \mathrm{O}$ into 0.1 aqueous solution of $\mathrm{Na}_{2} \mathrm{WO}_{4} \cdot 2 \mathrm{H}_{2} \mathrm{O}$ under constant stirring at RT was performed. The $\mathrm{pH}$ of the solution was not adjusted. Naturally tended to values close to $4(\mathrm{pH}=4.1$ for $\mathrm{x}=0.2, \mathrm{pH}=4.0$ for $\mathrm{x}=0.4, \mathrm{pH}=3.9$ for $\mathrm{x}=0.7$ and $\mathrm{pH}$ $=3.7$ for $\mathrm{x}=1)$.

For each of the compositions, the precipitates formed instanteneously with the addition of nitrates and were recovered immediately by centrifugation at 4000 rpm, during 5 min (NT 810, Novatecnica Piracicaba, Brazil). Subsequently, the precipitates were washed three times with anhydrous ethanol (Vetec, 99.9\%). The obtained precipitates were dryed in a conventional microwave oven for $3 \mathrm{~min}$.

The dried amorphous precipitates were heated at $600{ }^{\circ} \mathrm{C}$ for $1 \mathrm{~h}$ to evaluate crystal formation. Subsequently, the calcination process was carried out additionally for each composition at $950{ }^{\circ} \mathrm{C}$ for $10 \mathrm{~h}$. This process was done in order to obtain powders with larger crystallites, propicius for XRPD studies. The thermal treatments were performed in a horizontal tube furnace (Maitec-INTI FET 1600 / H, São Carlos, Brazil). 


\section{2.}

\section{Characterization techniques}

\subsection{1. \\ Differencial scanning calorimetry (DSC)}

Initially, all prepared compositions, in the amorphous state were analyzed on a Perkin-Elmer Simultaneous Thermal Analyzer STA-6000 (Seer Green, U.K.) equipment. The DSC technique allowed to establish an approximate temperature of crystallization of the amorphous material. The conditions were: heating rate 10 K.min ${ }^{-1}$, synthetic air flow $20 \mathrm{~mL} \cdot \mathrm{min}^{-1}$ and temperature range RT up to $950{ }^{\circ} \mathrm{C}$. (Appendix A. A1: TGA-DSC curves for $\mathrm{Al}_{2-\mathrm{x}} \mathrm{In}_{\mathrm{x}} \mathrm{W}_{3} \mathrm{O}_{12}$ as amorphous powders).

In order to verify possible phase transitions in the studied systems, once the calcination process had been carried out and the powders crystallized, the samples were subjected to an additional thermal analysis in a TA Instruments Q200 equipment, equipped with a liquid $\mathrm{N}_{2}$ cooling head under $\mathrm{He}$ purge gas (25 $\mathrm{mL} \cdot \mathrm{min}^{-1}$ ), with a heating rate of $20 \mathrm{~K} \cdot \mathrm{min}^{-1}$ over the temperature ranges from -100 ${ }^{\circ} \mathrm{C}$ to $0{ }^{\circ} \mathrm{C}$ and from $0{ }^{\circ} \mathrm{C}$ to $300{ }^{\circ} \mathrm{C}$.

In both cases about $20 \mathrm{mg}$ og each powder was used for analyses.

\subsection{2. Thermogravimetry (TGA)}

In order to determine hygroscopicity of the four chemical compositions from mass losses of water molecules, samples of $20 \mathrm{mg}$ (approximately) were analyzed in a Perkin-Elmer Simultaneous Thermal Analyzer STA-6000 (Seer Green, U.K.) equipment, for each composition in powder form. The samples were heated from RT to $950{ }^{\circ} \mathrm{C}$ with a heating rate of $10 \mathrm{~K} \cdot \mathrm{min}^{-1}$ using synthetic air flow of $20 \mathrm{~mL} \cdot \mathrm{min}^{-1}$. The samples analyzed for the 4 compositions were stored under ambient conditions (approximately $25^{\circ} \mathrm{C}$ and $78 \%$ relative humidity). However, strict monitoring or control of the atmosphere to which the samples were exposed was not carried out prior to the TGA test. 


\subsection{3.}

\section{X-ray power diffraction (XRPD)}

The calcined samples in powder form of $\mathrm{A}_{2-\mathrm{x}} \mathrm{In}_{\mathrm{x}} \mathrm{W}_{3} \mathrm{O}_{12}$ were analyzed for each composition using a Bruker D8 Advance diffractometer with Cu $\alpha$ radiation $(\lambda$ $=1.5418 \AA$ ), with a $2 \theta$ scanning step size of $0.01^{\circ}$. The analysis was carried out at RT in order to determine crystal system (monoclinic or orthorhombic) adopted by a phase at RT.

The diffractograms were analyzed using TOPAS-Academic software program and LeBail method.

\subsection{4.}

\section{High temperature X-ray power diffraction (HT-XRPD)}

This technique is also known as In-Situ XRPD. The equipment used was Bruker D8 Advance diffractometer with Cu $\alpha$ radiation $(\lambda=1.5418 \AA)$, with a $2 \theta$ scanning step size of $0.01^{\circ}$ and counting time of $2 \mathrm{~s}$ per step, with high-temperature Anton-Paar XRK900 camera.

The powders from of four compositions calcinated at $950{ }^{\circ} \mathrm{C}$ were analyzed at $25,50,100,150,200,250,300,350$ and $400{ }^{\circ} \mathrm{C}$ for approximately 24 hours. This technique makes it possible to measure the variations in the unit cell parameters with temperature. The as obtained diffractograms allow to identify possible phase transitions through the location of peaks and make possible calculation of intrinsic CTEs (linear) using unit cell parameters (with the standard uncertainties at the fourth decimal place) determined by Le Bail refinement using TOPAS-Academic software. The standard deviations for the intrinsic CTE were calculated from the linear fit in the temperature range from RT to $400{ }^{\circ} \mathrm{C}$.

\subsection{5.}

\section{Dilatometry}

Dilatometry is a technique that allows to follow the thermal expansion in bulk material through variations in the length of a cylindric sample. The equipment used was the DIL 402C NETZSCH dilatometer. The samples analyzed were solid cylinders of each synthesized composition. The dimensions of the samples were 6.5 $\mathrm{mm}$ in diameter by $8 \mathrm{~mm}( \pm 0.1 \mathrm{~mm})$ in length. The powders calcinated at $950{ }^{\circ} \mathrm{C}$ 
with the appropiate composition was mixed with $1 \%$ polyethyleneglycol and $1 \%$ polyvinyl alcohol water. Subsequently, these mixtures were pressed at $250 \mathrm{MPa}$. As a result, green bodies were obtained. These green bodies were sintered at $950{ }^{\circ} \mathrm{C}$ for $10 \mathrm{~h}$ in air.

The equipment was calibrated using a standard $\mathrm{Al}_{2} \mathrm{O}_{3}$ sample provided by the manufacturer (NETZSCH). Subsequently, Dilatometric measurements were performed three times for each sample in order to determine the extrinsic CTE and its standard deviations. The dilatometric curves were obtained from RT up to 500 ${ }^{\circ} \mathrm{C}$ with a heating rate of $5 \mathrm{~K} \cdot \mathrm{min}^{-1}$ and a cooling rate of $3 \mathrm{~K} \cdot \mathrm{min}^{-1}$.

\subsection{6.}

\section{Density}

To determine the density of each sintered composition, a density measurement kit was coupled to BEL Engineering M213Ai analytical balance and measurements of absolute density of the samples was carried out by the Archimedean method. Water temperature was measured to determine its density, according to ASTM B962-15.

\subsection{7. \\ Diffuse reflectance spectroscopy (DRS)}

DRS technique was used to determine the band-gap energy of the four compositions in the $\mathrm{Al}_{2-\mathrm{x}} \mathrm{In}_{\mathrm{x}} \mathrm{W}_{3} \mathrm{O}_{12}$ system. Assumed direct and indirect transition fundamental absorption. DRS was used to study the optical properties in all samples on a Perkin-Elmer Lambda $650 \mathrm{UV}$-vis spectrophotometer, in a range from $800 \mathrm{~nm}$ to $250 \mathrm{~nm}$ in $1 \mathrm{~nm}$ steps. The DRS spectra were plotted using the Kubelka-Munk function to estimate the band-gap energy 
5

\section{Results and Discussion}

\section{1.}

\section{Phase composition}

XRPD was firstly performed in order to determine if the studied compositions are monophasic. Subsequently, their diffractograms were adjusted by the Le Bail method. The XRPD patterns of $\mathrm{Al}_{2-\mathrm{x}} \mathrm{In}_{\mathrm{x}} \mathrm{W}_{3} \mathrm{O}_{12}$ at RT for each composition are shown in Figure 13.

The four compositions showed to be monophasic at RT. Le Bail's adjustment allowed determining that the compositions $\mathrm{x}=0.2,0.4,0.7$ present orthorhombic structures (space group 60, Pbcn). However, the XRPD pattern of composition $\mathrm{x}=1$ presented small differences with respect to the previous three compositions studied. Based on the previous literature reports [43] [44] [45], diffractogram of the composition $\mathrm{x}=1$ was expected to be orthorhombic with $\mathrm{Pbcn}$ space group, but some differences were found. The most intense peak located at $22.4^{\circ}$ (29) did not divide into two separate diffraction lines and additionally presented two weak diffraction lines located at $23.8^{\circ}$ and $25.9^{\circ}(2 \theta)$.

(a)

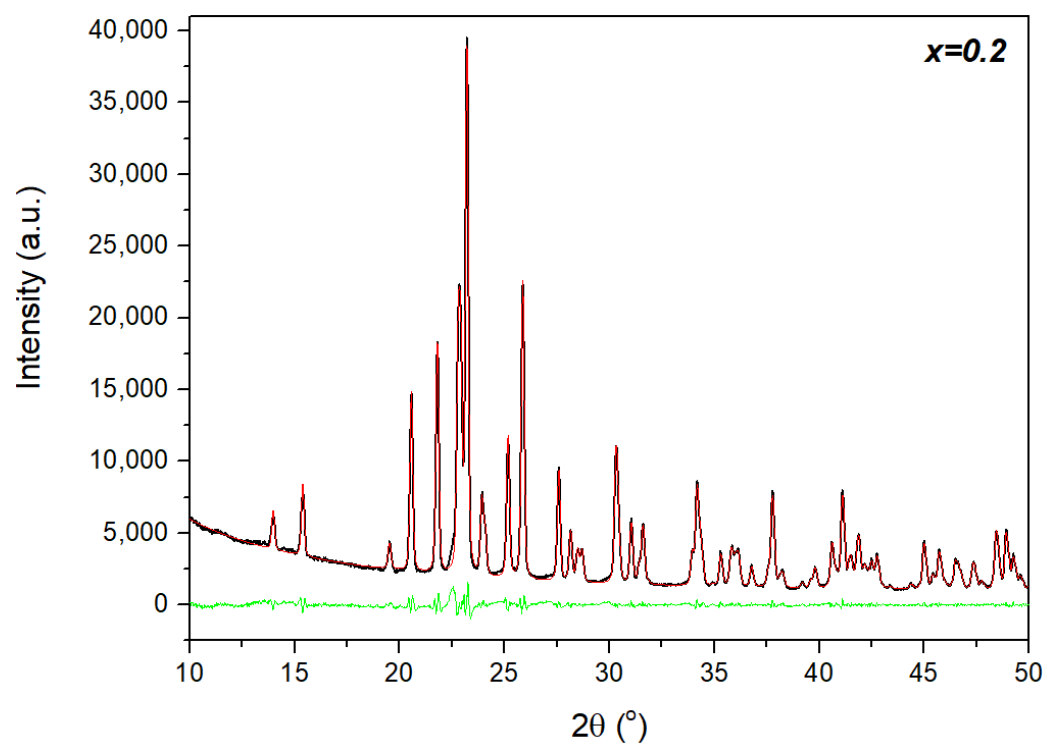


(b)

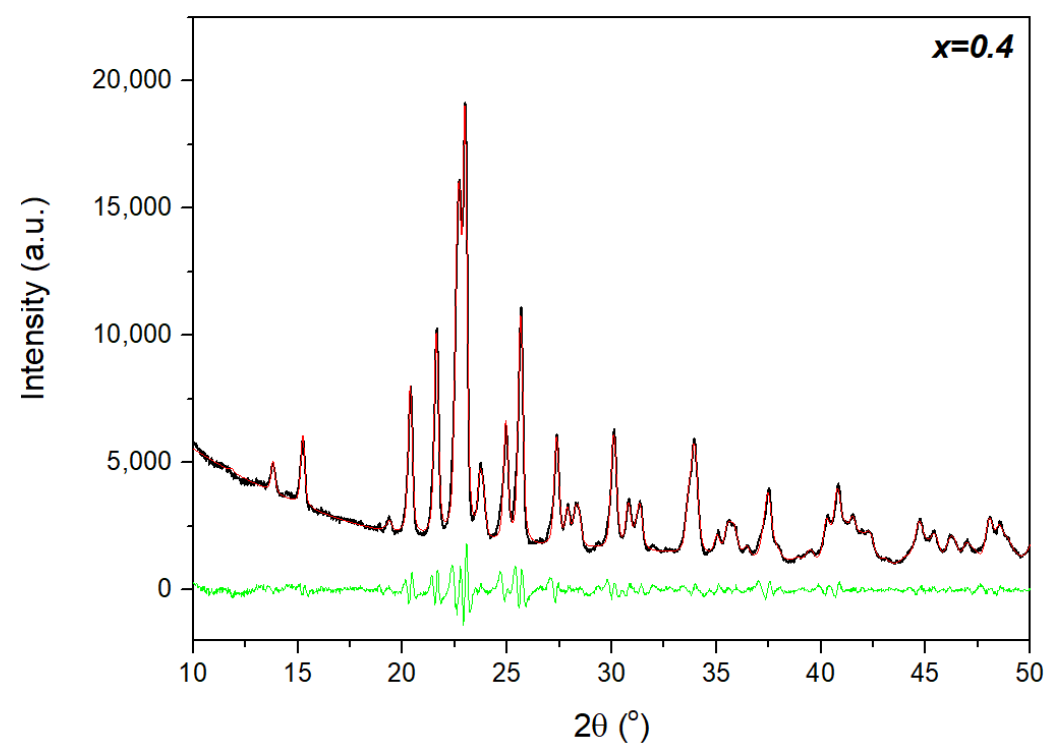

(c)

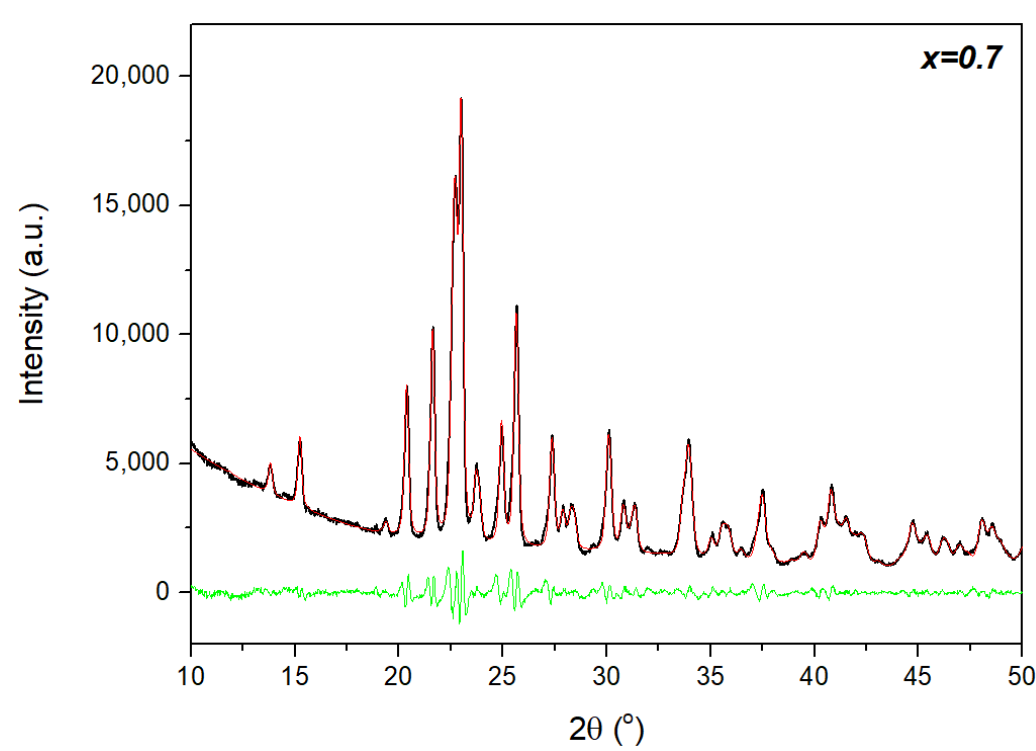


(d)

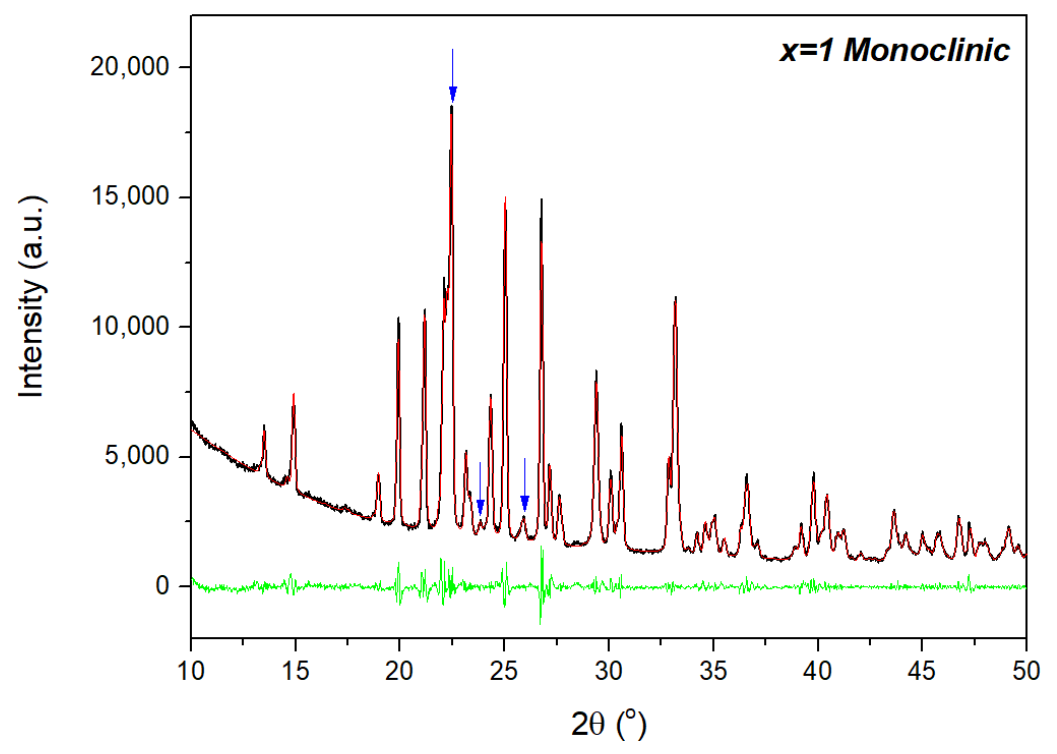

Figure 13- XRPD patterns of $\mathrm{Al}_{2-x} \mathrm{In}_{x} \mathrm{~W}_{3} \mathrm{O}_{12}$ obtained at $R T$. The Le Bail fit shows that the compositions (a) $x=0.2$, (b) $x=0.5$ and (c) $x=0.7$ coincide with the orthorhombic space group Pbcn. For the composition (d) $x=1$ the Le Bail fit shows that the composition coincides with the monoclinic space group $P 2_{1} / a$. Experimental profiles are represented by black lines, calculated profiles by red lines and difference profiles by green lines. (d) The arrows show typical diffraction lines for the monoclinic system in the $\mathrm{A}_{2} \mathrm{M}_{3} \mathrm{O}_{12}$ family, which are absent in the orthorhombic system.

The diffractograms obtained using XRPD allow us to determine the type of structure that a material adopts at RT. When a crystal of the $\mathrm{A}_{2} \mathrm{M}_{3} \mathrm{O}_{12}$ family assumes monoclinic structure, a higher intensity single peak arises close to $23^{\circ}(2 \theta)$ [51]. However, when it assumes an orthorhombic structure it divides into two peaks [52].

The appearance or absence of characteristic peaks in the monoclinic or orthorhombic structures for the $\mathrm{A}_{2} \mathrm{M}_{3} \mathrm{O}_{12}$ family was also reported by Miller et al. [11]. In this study, the authors determined the phase transition of $\mathrm{HfMgMo}_{3} \mathrm{O}_{12}$ from monoclinic structure to orthorhombic structure at $-98{ }^{\circ} \mathrm{C}$ using diffractograms obtained using the XRPD In Situ technique. The XRPD pattern for $\mathrm{x}=1$ was adjusted to the monoclinic system, which described all experimental diffraction lines very well. 
Another important characteristic determined from XRPD at RT was the lattice parameters. The results are found in Table 5. It is possible to notice the increase in the value of the lattice parameters of the $\mathrm{x}=1$ composition in relation to the $\mathrm{x}=0.2,0.4$ and 0.7 compositions. This shows that the composition $\mathrm{x}=1$ adopted a different type of structure than the other three compositions.

Table 5- Lattice parameters at $R T$ in $\mathrm{Al}_{2-\mathrm{x}} \operatorname{In}_{\mathrm{x}} \mathrm{W}_{3} \mathrm{O}_{12}$ system

\begin{tabular}{ccccc}
\hline Lattice parameter & $\begin{array}{c}\mathbf{a} \\
(\AA)\end{array}$ & $\begin{array}{c}\mathbf{b} \\
(\mathbf{\AA})\end{array}$ & $\begin{array}{c}\mathbf{c} \\
(\AA)\end{array}$ & $\begin{array}{c}\text { Volume } \\
\left(\AA^{3}\right)\end{array}$ \\
\hline $0.2(P b c n)$ & 12.6948 & 9.1107 & 9.2019 & 1064.2979 \\
$0.4(P b c n)$ & 12.7840 & 9.1567 & 9.2588 & 1083.8123 \\
$0.7(P b c n)$ & 12.9615 & 9.2866 & 9.3930 & 1130.6233 \\
$1\left(P 2_{1 / a} / a\right)^{*}$ & 16.1260 & 9.4955 & 18.7623 & 2343.8511 \\
\hline
\end{tabular}

The diffractograms obtained at RT suggested that the composition $\mathrm{x}=1$ adopts a monoclinic structure at RT and not orthorhombic. This contradicts what was previously proposed by Tzvetkov et al. [43], Koseva et al. [44] and Yordanova et al.[45].

\section{2. \\ Phase transition temperature}

\subsection{1.}

\section{Phase transition temperature. HT-XRPD technique}

In order to determine the phase transition between monoclinic and orthorhombic structures, the HT-XRPD technique was used. The temperature range for the HT-XRPD was $25{ }^{\circ} \mathrm{C}$ to $400{ }^{\circ} \mathrm{C}$. The diffraction patterns for compositions $\mathrm{x}=0.2,0.4$, and 0.7, shown in Figure 14 (a-c), were determined to remain almost identical as the temperature increased. Therefore, it could be concluded that these compositions do not present a phase transition and they are orthorhombic along the studied temperature interval up to $400{ }^{\circ} \mathrm{C}$. However, for the composition $\mathrm{x}=1$ 
(Figures 14 (d) and 15) small changes were found in the diffraction patterns. This indicates a possible phase transition from a monoclinic structure to orthorhombic structure.

(a)

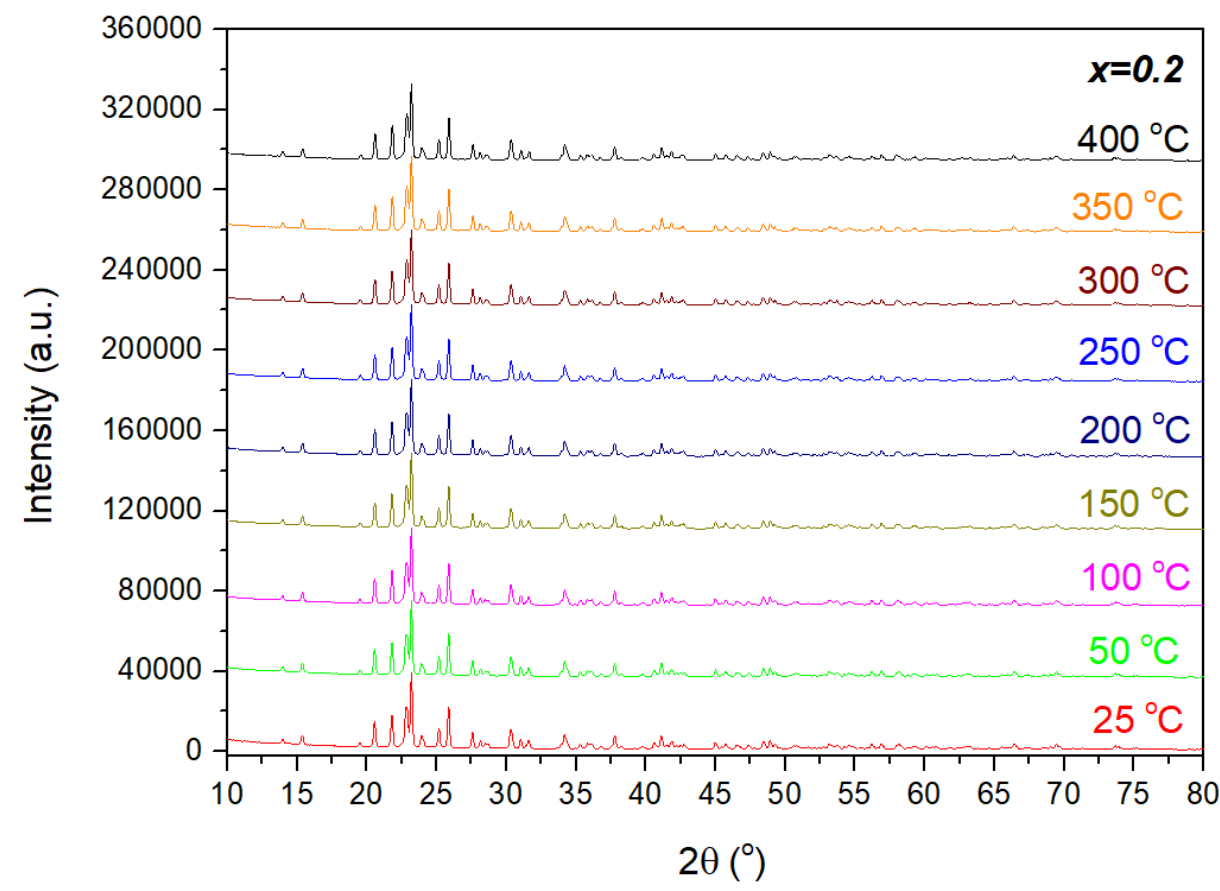

(b)

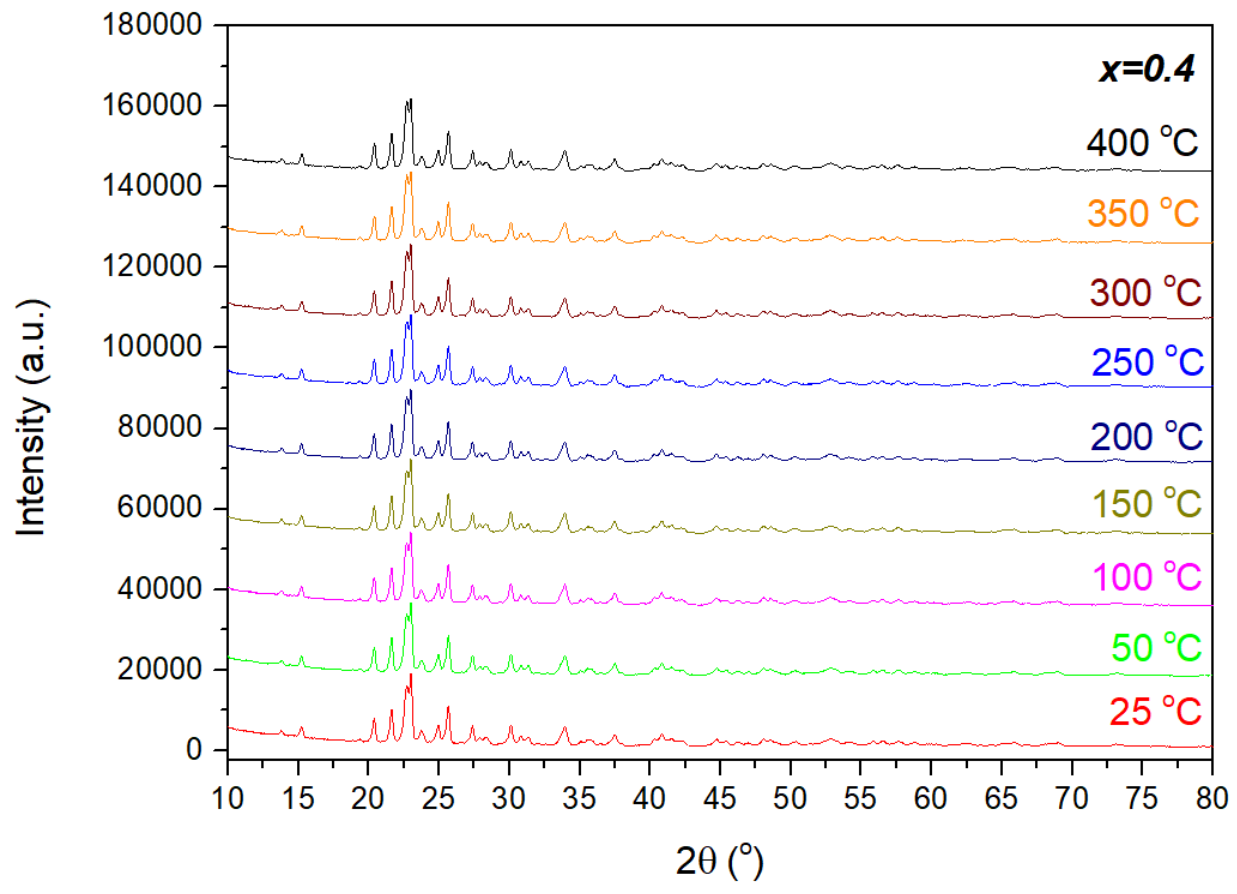


(c)

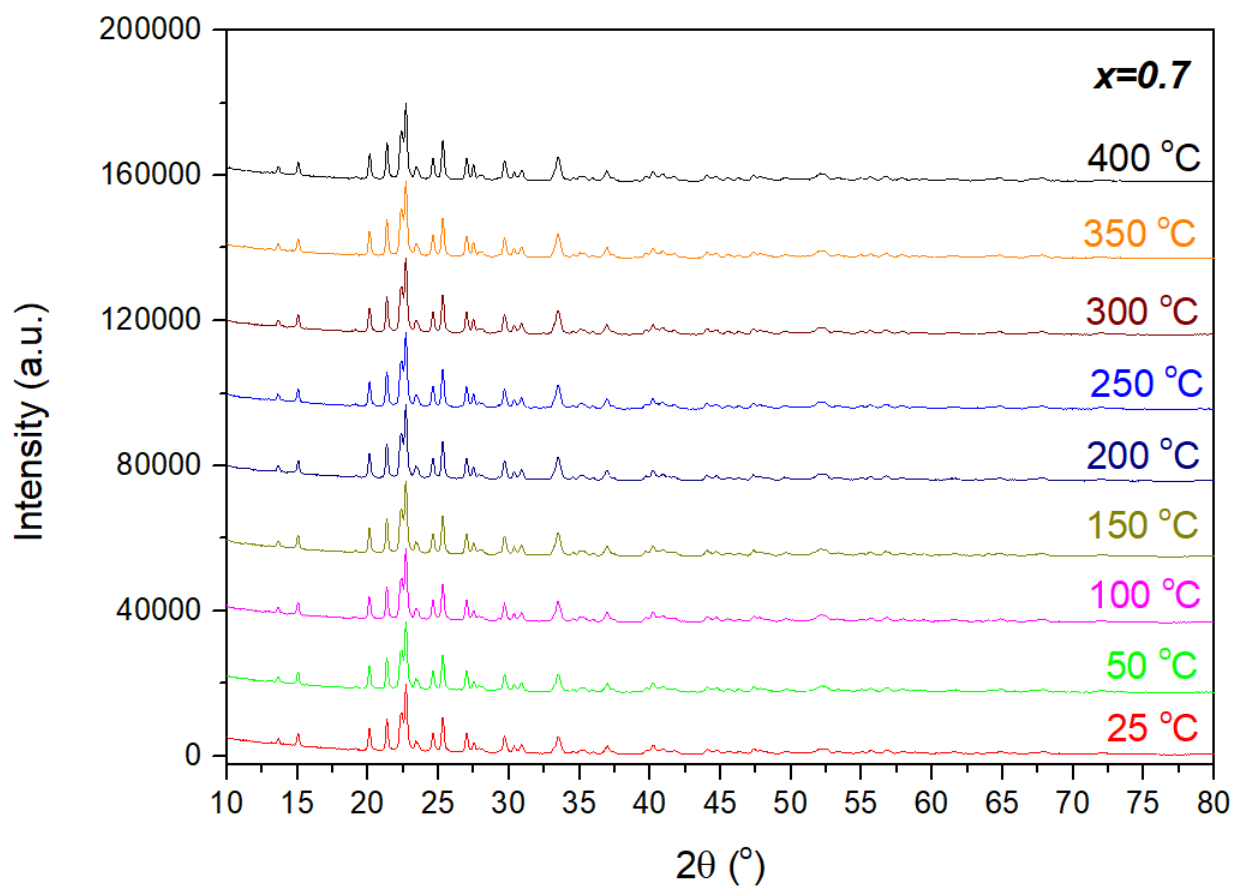

(d)

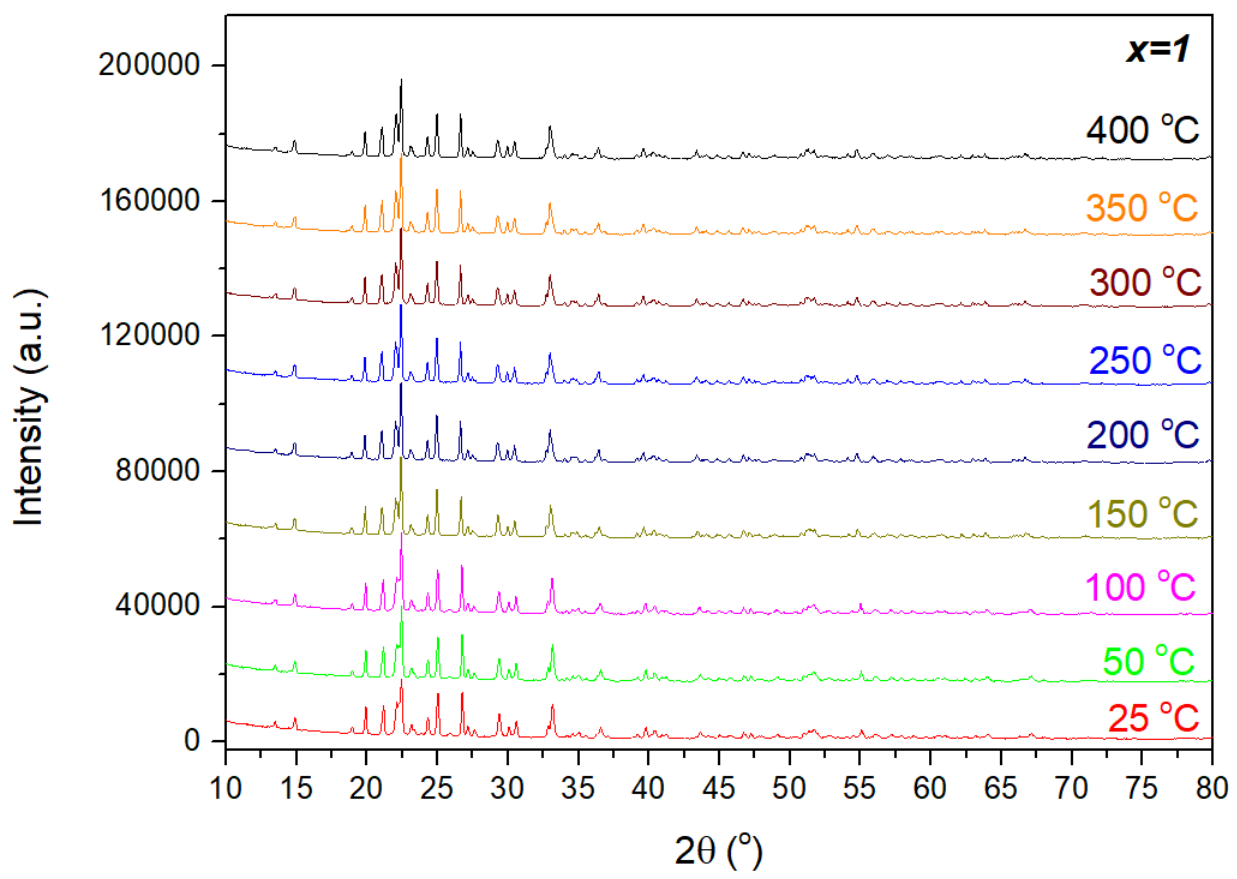

Figure 14- HT-XRPD patterns of $A l_{2-x} \ln _{x} W_{3} O_{12}$. For compositions (a) $x=0.2$, (b) $\mathrm{x}=0.4$ and (c) $\mathrm{x}=0.7$ the structures are orthorhombic from RT to $400{ }^{\circ} \mathrm{C}$. For composition (d) $x=1$ phase transition from monoclinic to orthorhombic structure occurs at $\sim 250{ }^{\circ} \mathrm{C}$. 
Note that the HT-XRPD pattern of the $\mathrm{x}=1$ phase changed to orthorhombic at $150{ }^{\circ} \mathrm{C}$, as evidenced by the disappearance of the two diffraction lines at $23.8^{\circ}$ and $25.9^{\circ}(2 \theta)$, as well as the most intense peak, close to $22.4^{\circ}(2 \theta)$, divided into two adjacent diffraction lines.

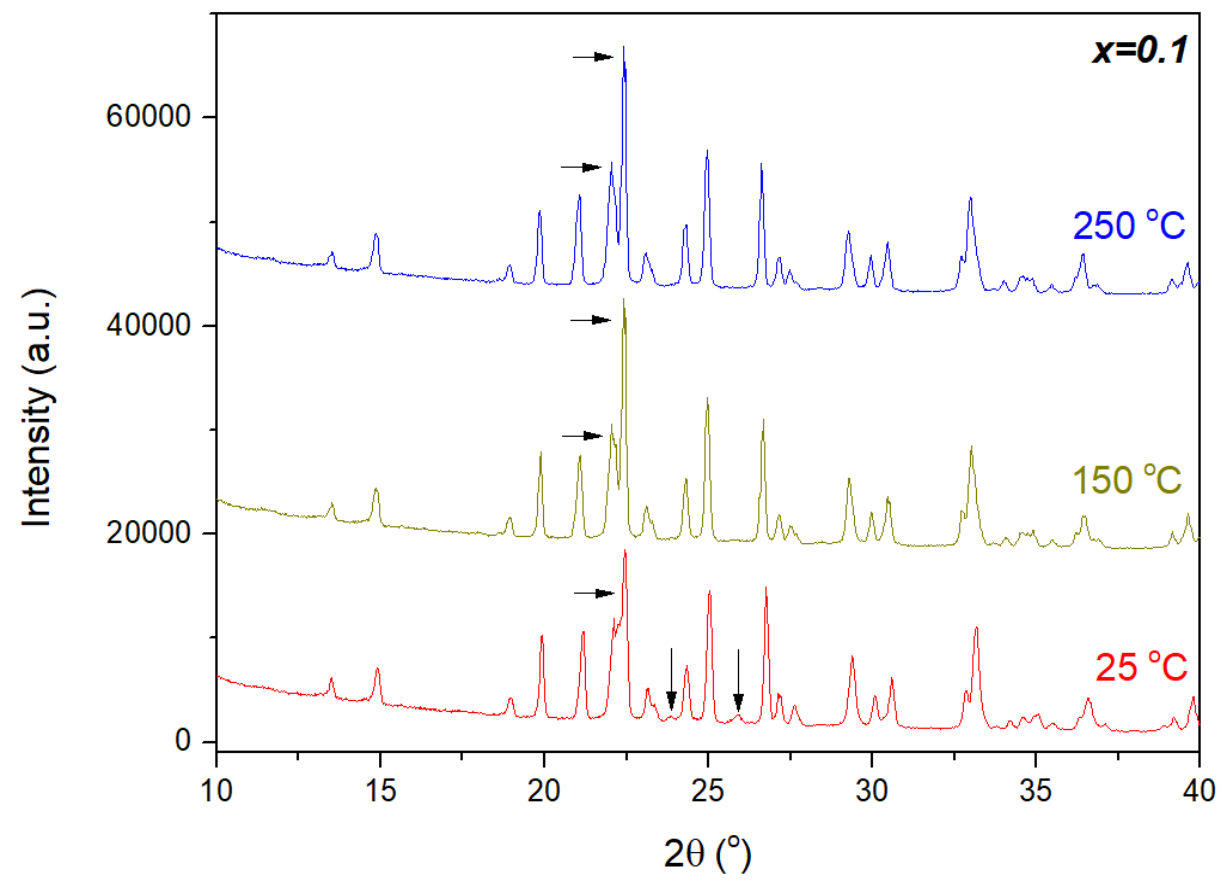

Figure 15- HT-XRPD patterns $x=1$ sample at three different temperatures. Arrows mark characteristic peaks for monoclinic system of the $\mathrm{A}_{2} \mathrm{M}_{3} \mathrm{O}_{12}$ family at $\mathrm{RT}$. As the temperature increases, these disappear. Additionally, at high temperatures the separation of the most intense peak in two diffraction lines indicates formation of orthorhombic structure of the $\mathrm{A}_{2} \mathrm{M}_{3} \mathrm{O}_{12}$ family.

\subsection{2.}

\section{Phase transition temperature. DSC technique}

Many of $\mathrm{A}_{2} \mathrm{M}_{3} \mathrm{O}_{12}$ family materials reported by Liu et al.[6] exhibit phase transitions at temperatures higher than RT. However, there are phases which adopt orthorhombic structure at temperatures below $0{ }^{\circ} \mathrm{C}$. This, for example, is the case of the $\mathrm{Al}_{2-\mathrm{x}} \mathrm{Sc}_{\mathrm{x}} \mathrm{W}_{3} \mathrm{O}_{12}$ for the compositions $\mathrm{x}=0.1,0.2,0.4$ [52].

Other materials reported from the $\mathrm{A}_{2} \mathrm{M}_{3} \mathrm{O}_{12}$ family that exhibit phase transitions at low temperatures are: $\mathrm{Al}_{2} \mathrm{~W}_{3} \mathrm{O}_{12}$ (Temperature of phase transition $\mathrm{T}_{\mathrm{PT}}$ ) $\mathrm{T}_{\mathrm{PT}}=-6{ }^{\circ} \mathrm{C}[39]$ and $\mathrm{T}_{\mathrm{PT}}=-20{ }^{\circ} \mathrm{C}[53], \mathrm{Sc}_{2} \mathrm{Mo}_{3} \mathrm{O}_{12}$ that conserved orthorhombic structure at low temperatures $\mathrm{T}_{\mathrm{PT}}=-93{ }^{\circ} \mathrm{C}$ [54]. In order to evaluate possible phase 
transitions in $\mathrm{Al}_{2-\mathrm{x}} \mathrm{In}_{\mathrm{x}} \mathrm{W}_{3} \mathrm{O}_{12}$. DSC tests were carried over the temperature range from $-100{ }^{\circ} \mathrm{C}$ to $300{ }^{\circ} \mathrm{C}$. The results are shown in Figure 16 .

(a)

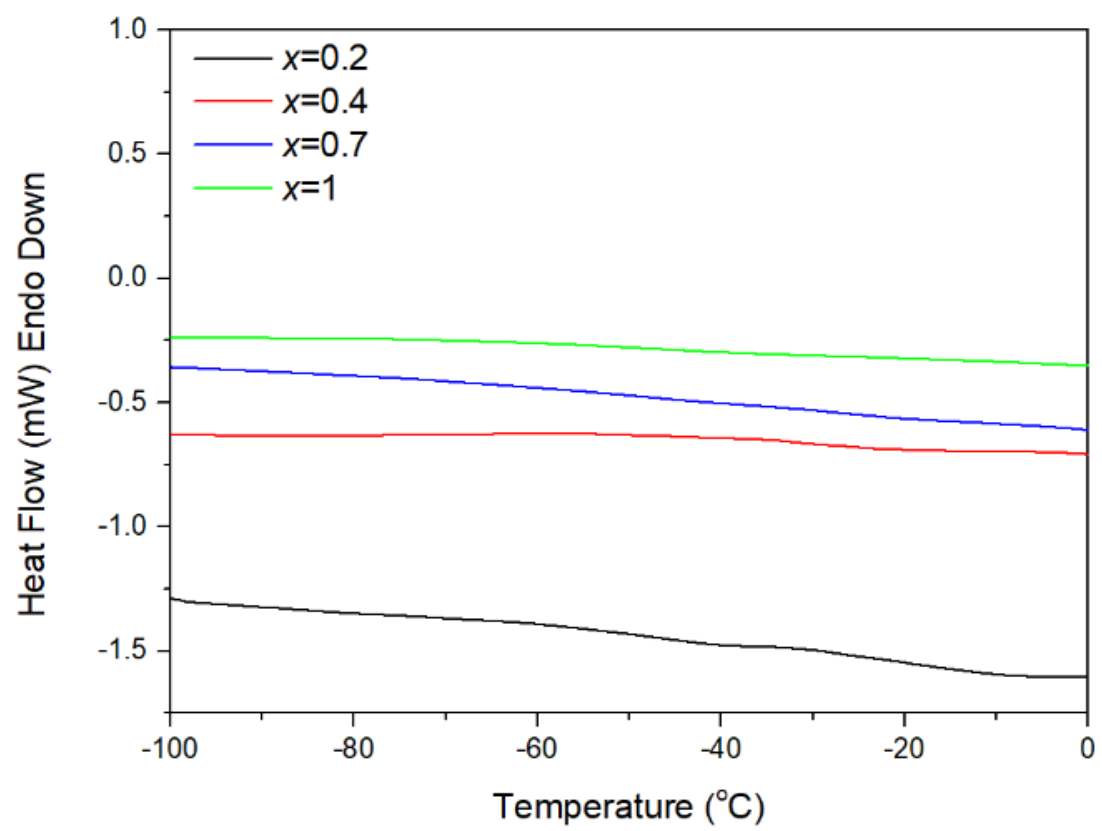

(b)

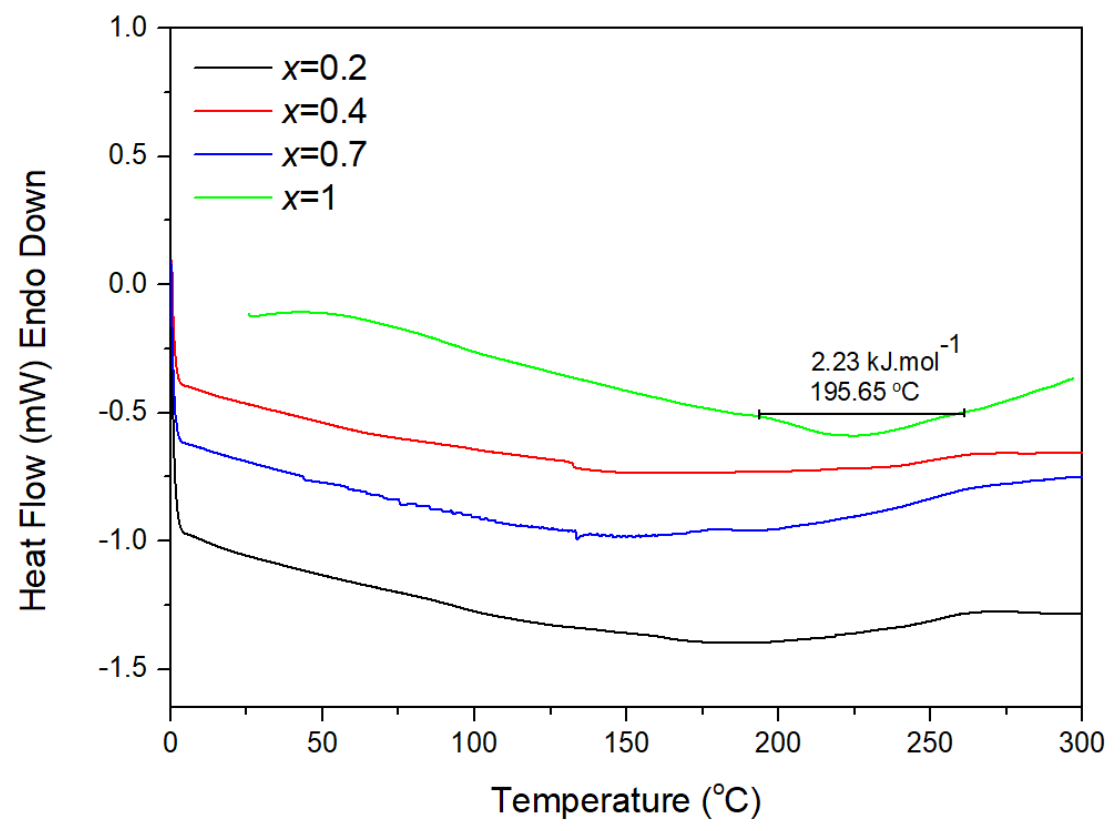

Figure 16- DSC curves in the $\mathrm{Al}_{2-\mathrm{x}} \ln _{\mathrm{x}} \mathrm{W}_{3} \mathrm{O}_{12}$ for que $\mathrm{x}=0.2,0.4,0.7$ and 1 compositions. (a) cryogenic temperatures, (b) RT and above RT. For the $x=1$ composition, the onset temperature of the monoclinic to orthorhombic phase transition and enthalpy of phase transition are presented. 
For the $\mathrm{x}=1$ composition, DSC curve over the temperature range from $0{ }^{\circ} \mathrm{C}$ to $300{ }^{\circ} \mathrm{C}$ are showed in Figure 16 (b). This Figure exhibit an endothermic peak with the onset close to $195{ }^{\circ} \mathrm{C}$ and phase transition enthalpy of $2.32 \mathrm{~kJ} \mathrm{~mol}^{-1}$. This peak was attributed to the phase transition from monoclinic to orthorhombic, caused by the breaking of secondary bonds between neighboring polyhedral [1]. The DSC curves do not show indications of phase transitions for $\mathrm{x}=0.2,0.4$ and 0.7 compositions in the studied range of temperatures $\left(-100{ }^{\circ} \mathrm{C}\right.$ to $\left.300{ }^{\circ} \mathrm{C}\right)$. However, two small artefacts were recorded at approximately $130{ }^{\circ} \mathrm{C}$ for the samples $\mathrm{x}=0.4$ and 0.7 . They were not corroborated or attributed to any change in the samples using other techniques (XRPD, HT-XRPD or dilatometry).

\subsection{3.}

\section{Phase transition temperature. Dilatometry technique}

The dilatometric curves obtained for the four compositions are shown in Figure 17. The curves acquired for the compositions $\mathrm{x}=0.2,0.4$ and 0.7 do not present phase transition features and, therefore, confirms the maintainance of orthorhombic structure for these compositions in the temperature range from RT to $500{ }^{\circ} \mathrm{C}$. However, the dilatometric curve obtained for the sample $\mathrm{x}=1$ clearly shows the phase transition, characterized by an abrupt increase of volume, localized between $150{ }^{\circ} \mathrm{C}$ and $220{ }^{\circ} \mathrm{C}$ (Figure $17(\mathrm{~d})$ ).

(a)

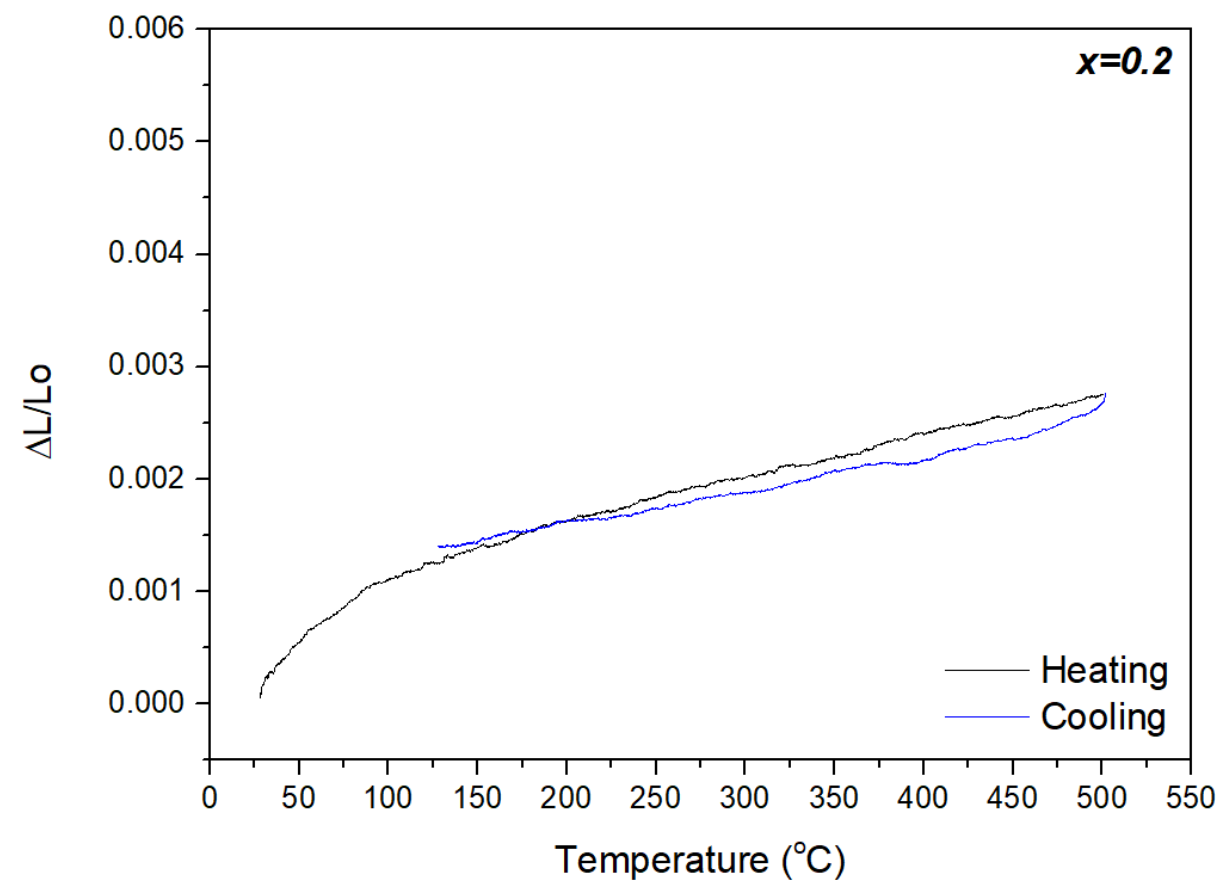


(b)

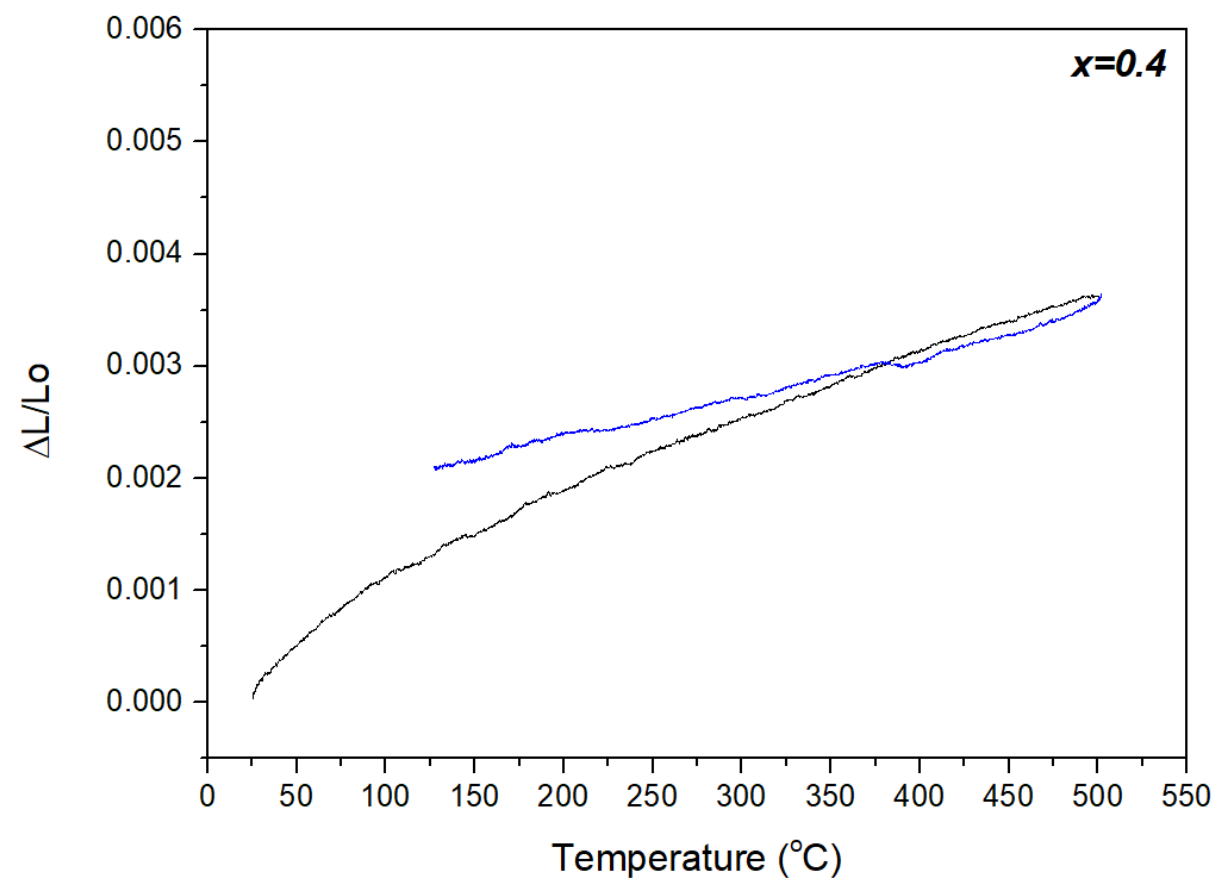

(c)

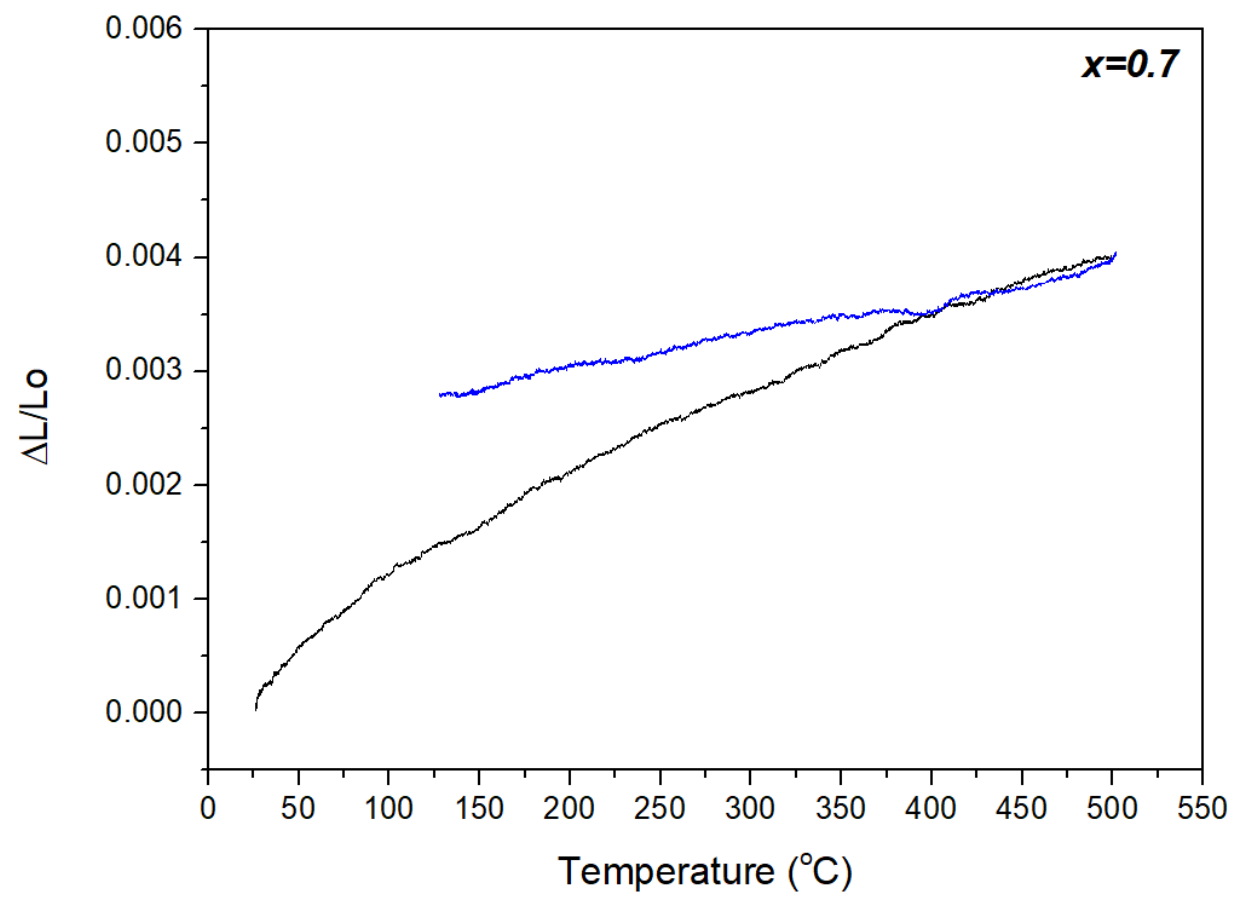


(d)

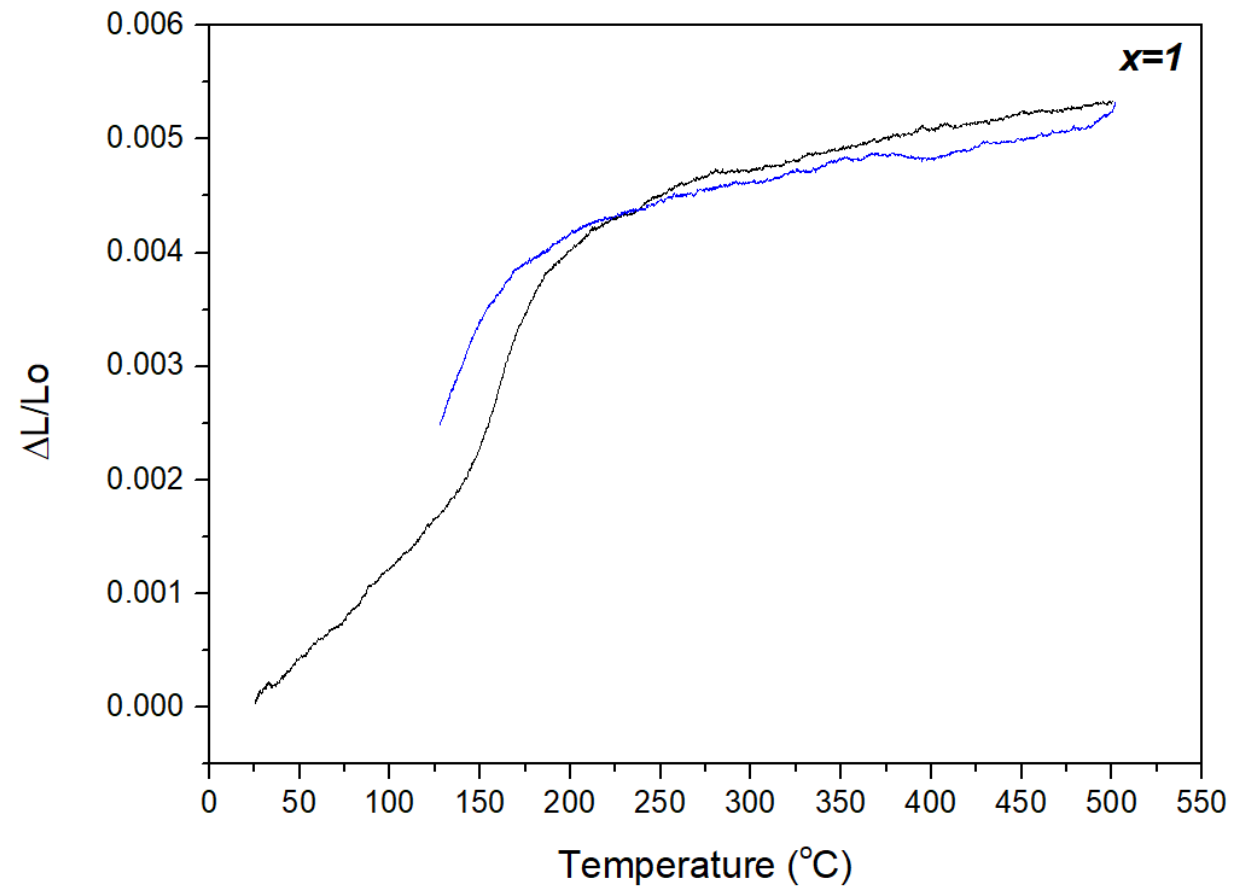

Figure 17- Dilatometric curves of $\mathrm{Al}_{2-x} \ln _{x} \mathrm{~W}_{3} \mathrm{O}_{12}$ system. (a) $\mathrm{x}=0.2$, (b) $\mathrm{x}=0.4$, (c) $x=0.7$ and $(d) x=1$. For $x=1$ there is monoclinic to orthorhombic phase transition, situated between $150{ }^{\circ} \mathrm{C}$ and $250{ }^{\circ} \mathrm{C}$.

\subsection{4.}

\section{Vegard's rule applied to $\mathrm{Al}_{2-\mathrm{x}} \ln _{\mathrm{x}} \mathrm{W}_{3} \mathrm{O}_{12}$ system}

Vegard's rule was applied to certify the incorporation of $\mathrm{In}^{3+}$ inside the orthorhombic structure for the four studied composition. This rule establishes that the lattice parameters of the unit cells vary linearly when a partial and continuous substitution of the ions that are part of a solid solution composition, is carried out. Although the rule was established empirically, it allows to follow substitutional behavior between ions within a crystalline phase [55]. In this case, $\mathrm{Al}^{3+}$ was substituted by $\operatorname{In}^{3+}$.

Vegard's rule was verified fot the lattice parameters obtained at $250{ }^{\circ} \mathrm{C}$ in $\mathrm{Al}_{2-\mathrm{x}} \mathrm{In}_{\mathrm{x}} \mathrm{W}_{3} \mathrm{O}_{12}$ system where all four compositions are orthorhombic. The results are exhibited in Figure 18. These results strongly suggested that $\mathrm{In}^{3+}$ substitutionally incorporated the place of $\mathrm{Al}^{3+}$ within octahedra increasing, therefore, the lattice 
parameters of the unit cell and obeys Vegard's rule. Due to the difference between the ionic radius of $\mathrm{Al}^{3+}(0.535 \AA)$ and $\operatorname{In}^{3+}(0.80 \AA)$ [56].

(a)

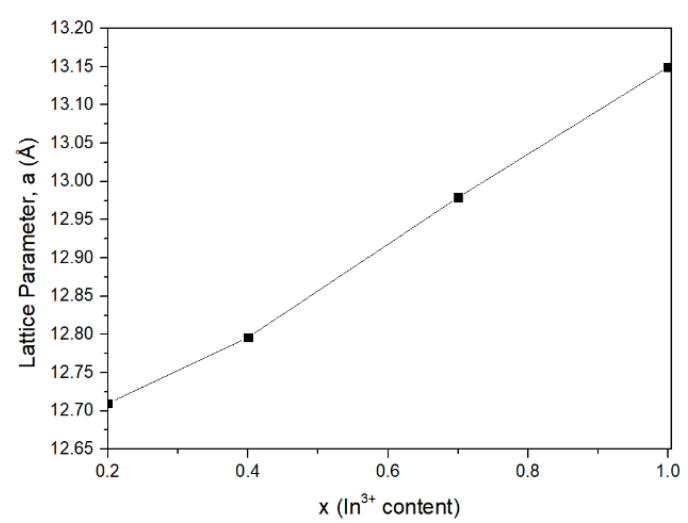

(c)

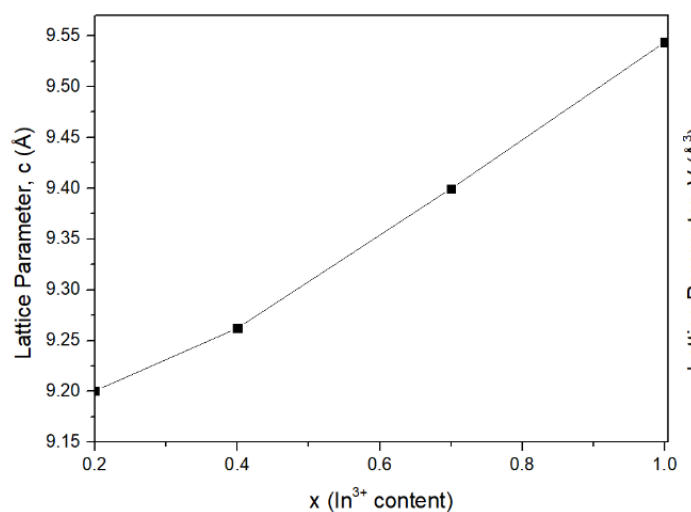

(b)

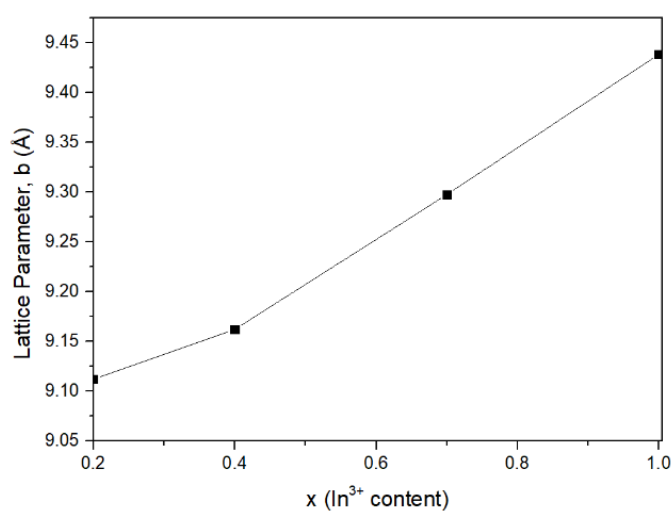

(d)

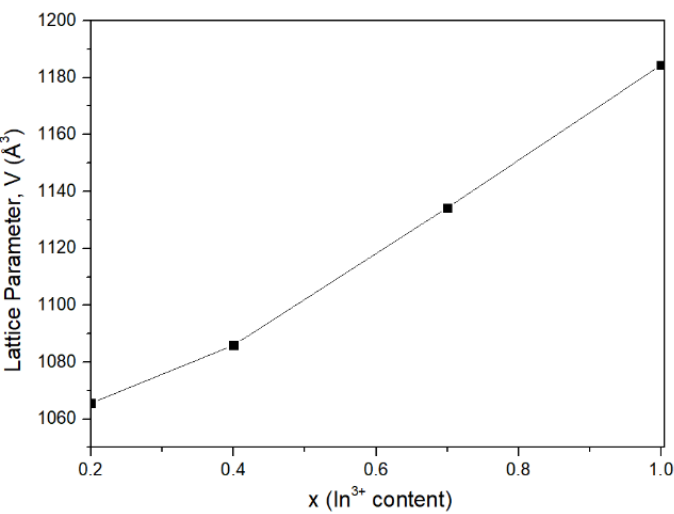

Figure 18- Vegard rule applied for $\mathrm{Al}_{2-\mathrm{x}} \mathrm{In}_{\mathrm{x}} \mathrm{W}_{3} \mathrm{O}_{12}$ system with $\mathrm{x}=0.2,0.4,0.7$ and 1 . Orthorhombic lattice parameters at $250{ }^{\circ} \mathrm{C}$ as a function of $\mathrm{In}^{3+}$ content are presented.

\subsection{5.}

\section{Phase transition temperature in $\mathrm{Al}_{2-x} \mathrm{In}_{\mathrm{x}} \mathrm{W}_{3} \mathrm{O}_{12}$ system}

The data obtained by XRPD, HT-XRPD, DSC and dilatometry support the monoclinic structure, $\mathrm{P} 22_{1} / \mathrm{a}$ space group, for the composition $\mathrm{x}=1$ in the $\mathrm{Al}_{2}$ ${ }_{x} \operatorname{In}_{\mathrm{x}} \mathrm{W}_{3} \mathrm{O}_{12}$ system at $\mathrm{RT}$. This composition exhibits phase transition from a monoclinic structure to orthorhombic structure at a temperature of approximately $150{ }^{\circ} \mathrm{C}$. However, these findings do not agree with some previously reports [19] [30] [43] [44]. 
Mary and Sleight [19] concluded that the composition $\mathrm{x}=1$ of the $\mathrm{Al}_{2}$ ${ }_{x} \mathrm{In}_{\mathrm{x}} \mathrm{W}_{3} \mathrm{O}_{12}$ system does not present phase transitions between $25{ }^{\circ} \mathrm{C}$ and $800{ }^{\circ} \mathrm{C}$. Koseva et al. [30] concluded that $\mathrm{Alnn}_{3} \mathrm{O}_{12}$ has an orthorhombic structure at RT. Tzvetkov et al. [43] affirmed that all studied phases $(\mathrm{x}=0,0.2,0.6,1$ and 1.6) present orthorhombic structure at RT. Koseva et al [44] reported the phase transition temperatures showed in a Table 6.

Table 6- Phase transition temperature in $\mathrm{Al}_{2-\mathrm{x}} \mathrm{In}_{\mathrm{x}} \mathrm{W}_{3} \mathrm{O}_{12}$ system reported by Koseva et al. [44].

\begin{tabular}{cccccccc}
\hline $\begin{array}{c}\text { x value } \\
\left(\operatorname{In}^{3+} \text { Content }\right)\end{array}$ & $\mathbf{0}$ & $\mathbf{0 . 5}$ & $\mathbf{1 . 0}$ & $\mathbf{1 . 1}$ & $\mathbf{1 . 3}$ & $\mathbf{1 . 5}$ & $\mathbf{2 . 0}$ \\
\hline TPT & & Not detected above 25 & 118 & 181 & 254 \\
{$\left[{ }^{\circ} \mathrm{C}\right]$} & & & & & & \\
\hline
\end{tabular}

TРт: Transition phase temperature.

The inconsistencies found between previous studies can probably be attributed to an error in the interpretation of the results. These types of inconsistencies were reported by Truitt et al. [57] for the $\mathrm{Fe}_{1.5} \mathrm{Y}_{0.5} \mathrm{Mo}_{3} \mathrm{O}_{12}$ system. A study previous to that of Truitt et al. reported erroneously phase transition temperature to the orthorhombic system at $-170^{\circ} \mathrm{C}$, although it occurs ar much higer temperatures [28].

On the other hand, for compositions $\mathrm{x}=0.2,0.4$ and 0.7 , no phase transition from monoclinic to orthorhombic structure was detected in the temperature range from $-100{ }^{\circ} \mathrm{C}$ to $300{ }^{\circ} \mathrm{C}$. This characteristic of the $\mathrm{Al}_{2-\mathrm{x}} \mathrm{In}_{\mathrm{x}} \mathrm{W}_{3} \mathrm{O}_{12}$ system does not follow the electronegativity rule presented by Sleight et al. [38]. In $\mathrm{A}_{2} \mathrm{M}_{3} \mathrm{O}_{12}$ family, the transition temperature from monoclinic to orthorhombic structure does not depend on the size of the cation $A^{3+}$. However, if the electronegativity of member $A^{3+}$ increases, the effective (real) charge on the oxygen ions is reduced and as a consequence there is less repulsion between them. Less repulsion leads to the formation of the secondary bonds between the neighbouring oxygens increasing, therefore, the phase transition temperature [18] [38] [58].

The electronegativity rule would suggest that the transition temperature for the $\mathrm{Al}_{2-\mathrm{x}} \mathrm{In}_{\mathrm{x}} \mathrm{W}_{3} \mathrm{O}_{12}$ system should be between the phase transition temperatures of 
the end members; $\mathrm{Al}_{2} \mathrm{~W}_{3} \mathrm{O}_{12}\left(\mathrm{~T}_{\mathrm{PT}}=-22^{\circ} \mathrm{C}\right)$ and $\operatorname{In}_{2} \mathrm{~W}_{3} \mathrm{O}_{12}\left(\mathrm{~T}_{\mathrm{PT}}=250{ }^{\circ} \mathrm{C}\right)$. However, this behavior was not observed in the $\mathrm{Al}_{2-\mathrm{x}} \mathrm{In}_{\mathrm{x}} \mathrm{W}_{3} \mathrm{O}_{12}$ system for the compositions $\mathrm{x}=0.2,0.4$ and 0.7 . Other interesting exceptions to the electronegativity rule have been found in the $\mathrm{A}_{2} \mathrm{M}_{3} \mathrm{O}_{12}$ family. The $\mathrm{Al}_{2-\mathrm{x}} \mathrm{Sc}_{\mathrm{x}} \mathrm{W}_{3} \mathrm{O}_{12}$ system [23] [59] and $\mathrm{AlScMo}_{3} \mathrm{O}_{12}$ [57] are such examples.

Regarding to this behavior, Truitt et al. [57] proposed that this is due to the difference between the radii of the cations that occupy the octahedral site $\left(A^{3+}\right.$ and $\left.B^{3+}\right)$. In the system studied by Truitt et al. the relationship between radii $\mathrm{Al} / \mathrm{Sc}=$ 0.72 . For our system the relationship; $\mathrm{Al} / \mathrm{In}=0.67$, showing a higher difference between the radii of cations. This difference between the radii might explain the non-existence of the phase transition from monoclinic to orthorhombic structure in the compositions $\mathrm{x}=0.2,0.4$ and 0.7 of the $\mathrm{Al}_{2-\mathrm{x}} \mathrm{In}_{\mathrm{x}} \mathrm{W}_{3} \mathrm{O}_{12}$ system. However, this consideration does not apply to the composition $\mathrm{x}=1$. In this case, the transition phase temperature (approximately $150{ }^{\circ} \mathrm{C}$ ) meets to the electronegativity rule.

Regarding to this unusual behavior (phase transition suppression between monoclinic and orthorhombic structures) the reported results do not have a satisfactory explanation. The suppression of the phase transition does not align with expectations based on the electronegativity. This type of findings in these materials, added to others reported in the literature, indicates that the existence of other mechanisms that influence the transition from monoclinic to orthorhombic phase in addition to the electronegativity of the $A^{3+}$ cation.

\section{3.}

\section{Coefficient of thermal expansion CTE}

\subsection{1.}

\section{Intrinsic CTE}

The four compositions of the $\mathrm{Al}_{2-\mathrm{x}} \mathrm{In}_{\mathrm{x}} \mathrm{W}_{3} \mathrm{O}_{12}$ system were studied using the HT-XRPD technique, evaluating the lattice parameters changes of the system for each composition as a function of temperature. The acquired data were plotted as natural logarithms of unit-cell parameters ( $a, b$ and $c$ ) and unit-cell volumes as function of temperature. The results are shown in Figures 19 to 23. The volume shows a linear CTE but the lattice parameters present a slight deviation from linearity. The linear CTEs obtained by HT-XRDP are summarized in Table 7. 
Table 7- Intrinsic CTEs along each crystallographic axis $\left(\alpha_{a}, \alpha_{b}, \alpha_{c}\right)$, average linear CTE $\left(\alpha_{1}\right)$ in $\mathrm{Al}_{2-x} \ln _{\mathrm{x}} \mathrm{W}_{3} \mathrm{O}_{12}$ system and standard deviations for $\mathrm{x}=0.2,0.4,0.7$ and 1 compositions.

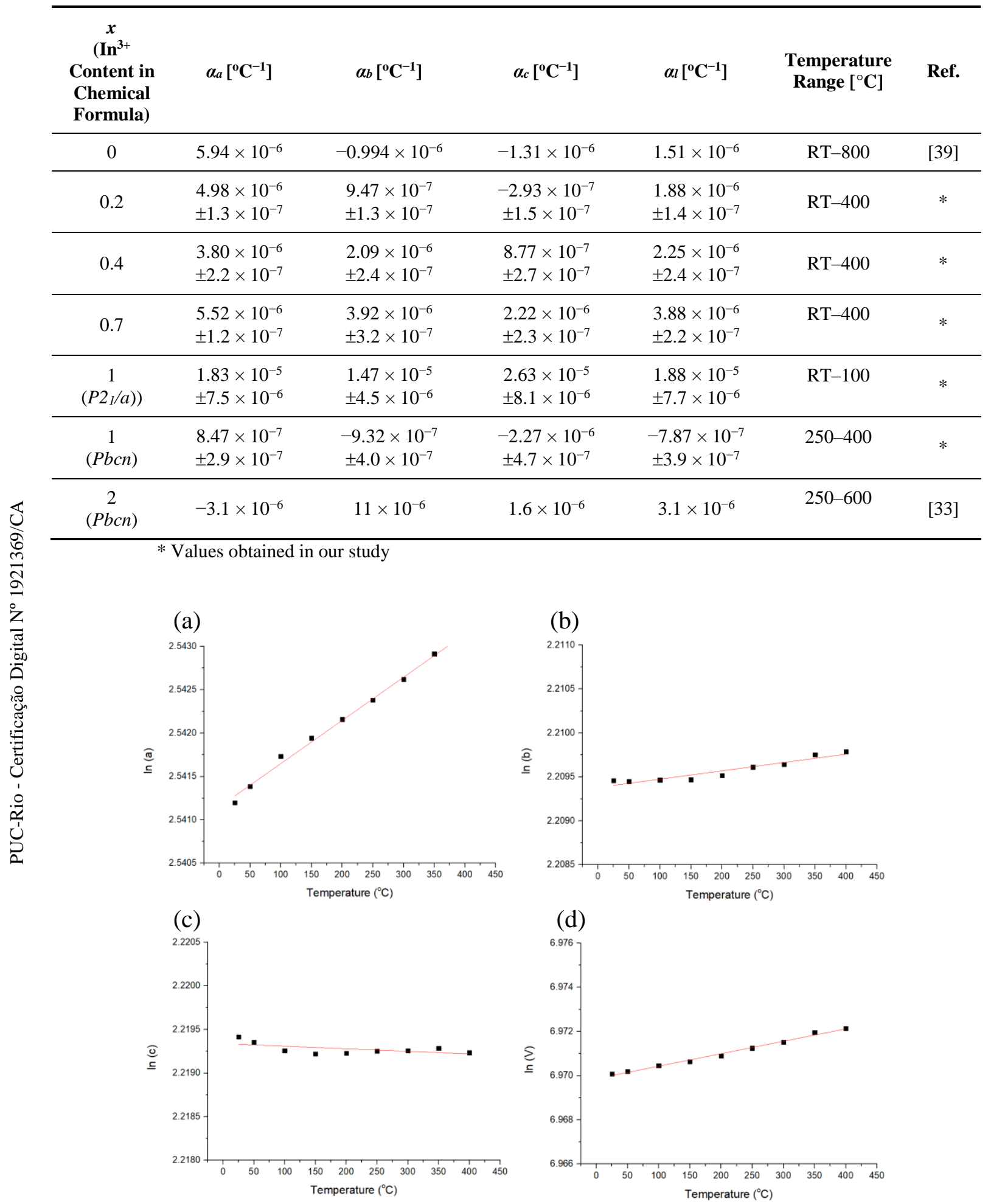

Figure 19 - Natural logarithmic variations of unit-cell parameters $(a, b$ and $c)$ and unit-cell volume as function of temperature for $x=0.2$ composition in $\mathrm{Al}_{2-\mathrm{x}} \mathrm{In}_{\mathrm{x}} \mathrm{W}_{3} \mathrm{O}_{12}$ system. 
(a)

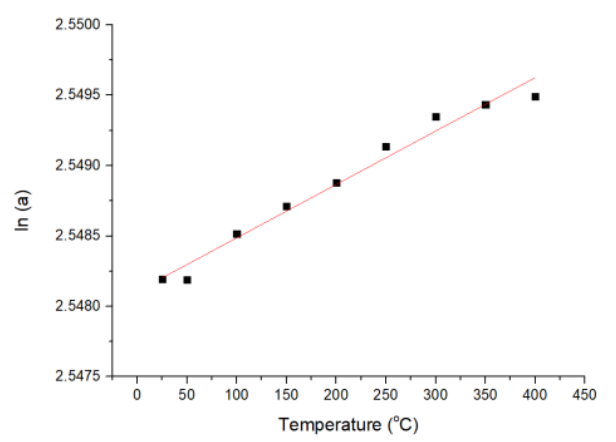

(c)

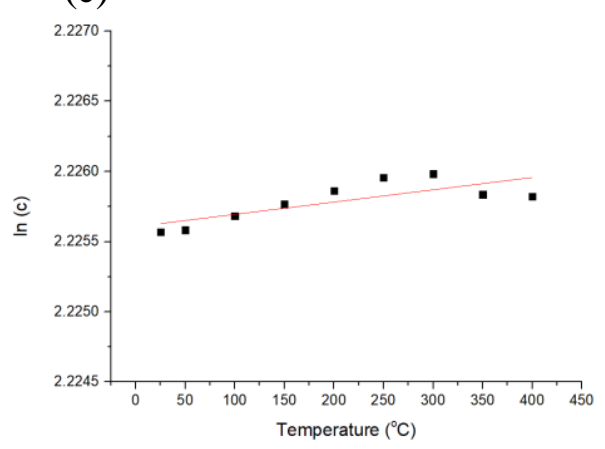

(b)

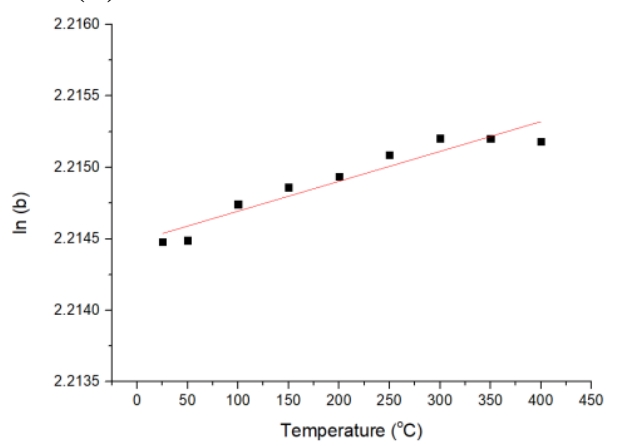

(d)

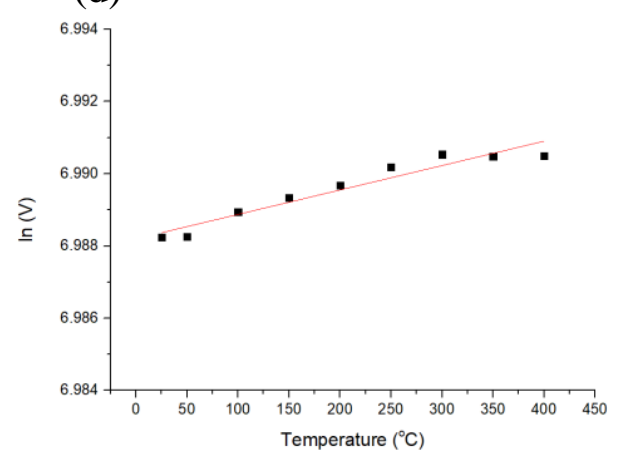

Figure 20- Natural logarithmic variations of unit-cell parameters $(a, b$ and $c)$ and unit-cell volume as function of temperature for $\mathrm{x}=0.4$ composition in $\mathrm{Al}_{2-\mathrm{x}} \mathrm{In}_{\mathrm{x}} \mathrm{W}_{3} \mathrm{O}_{12}$ system.

(a)

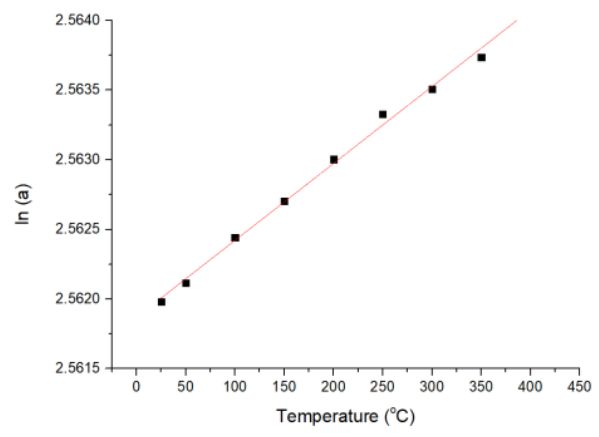

(c)

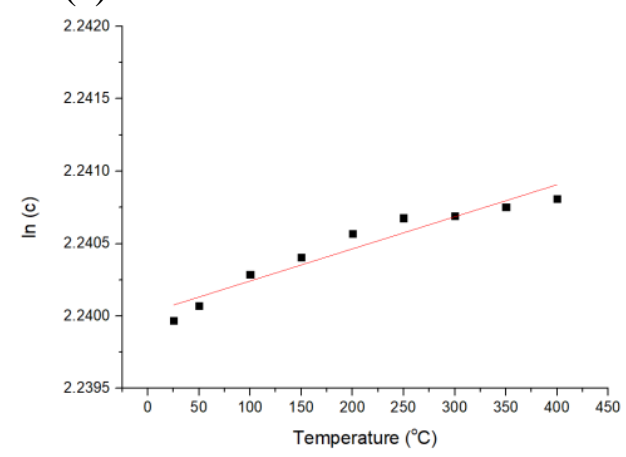

(b)

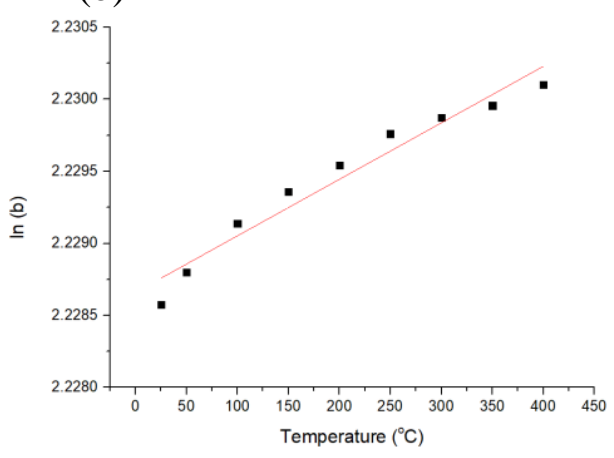

(d)

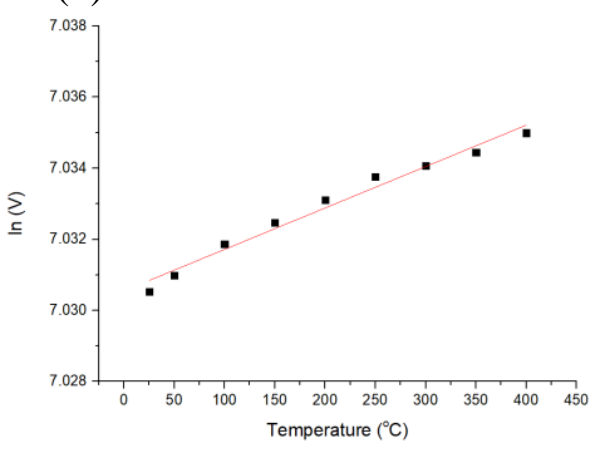

Figure 21- Natural logarithmic variations of unit-cell parameters (a, b and c) and unit-cell volume as function of temperature for $x=0.7$ composition in $\mathrm{Al}_{2-\mathrm{x}} \ln _{\mathrm{x}} \mathrm{W}_{3} \mathrm{O}_{12}$ system. 
(a)

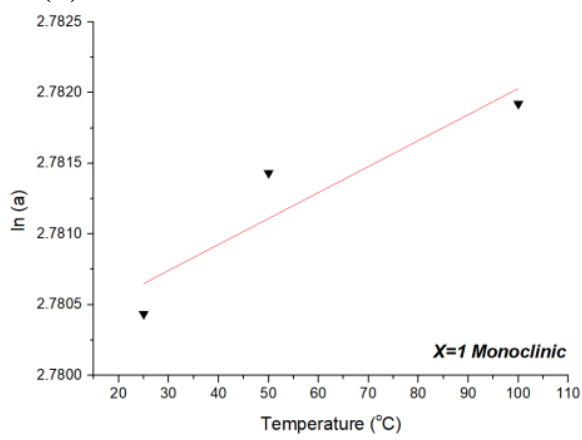

(c)

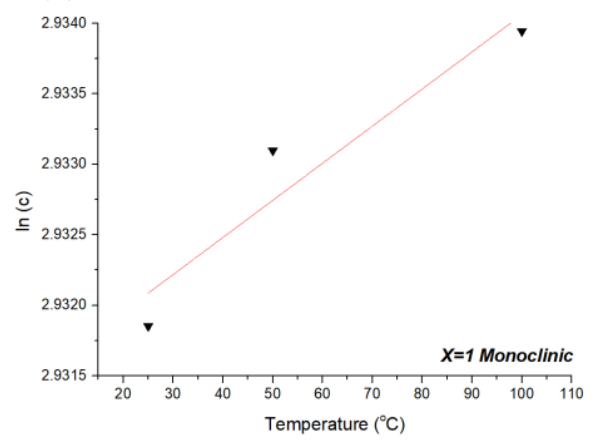

(b)

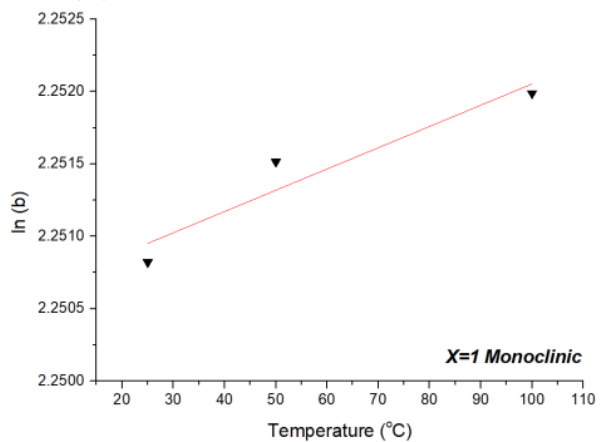

(d)

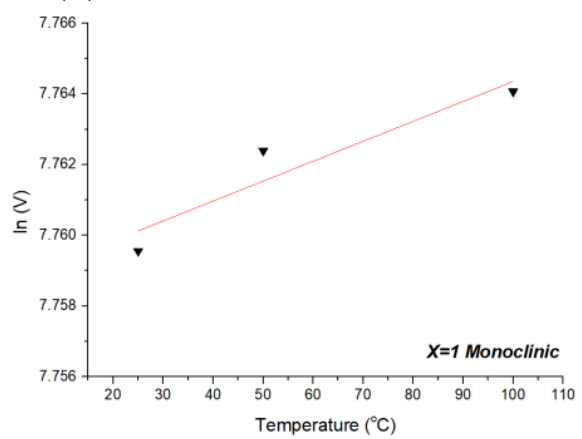

Figure 22- Natural logarithmic variations of unit-cell parameters ( $a, b$ and $c$ ) and unit-cell volume as function of temperature for $\mathrm{x}=1$ monoclinic structure in $\mathrm{Al}_{2}$ ${ }_{x} \ln _{x} \mathrm{~W}_{3} \mathrm{O}_{12}$ system.

(a)

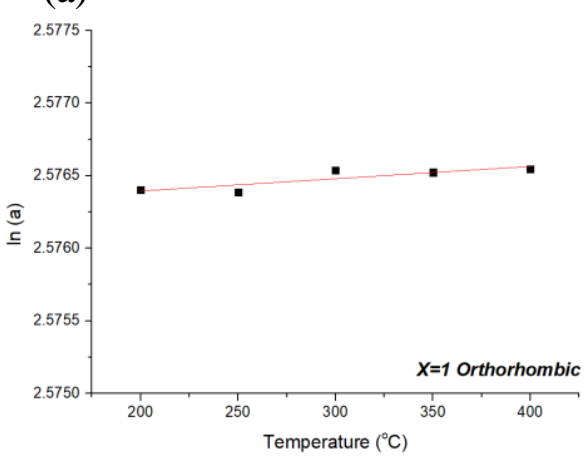

(c)

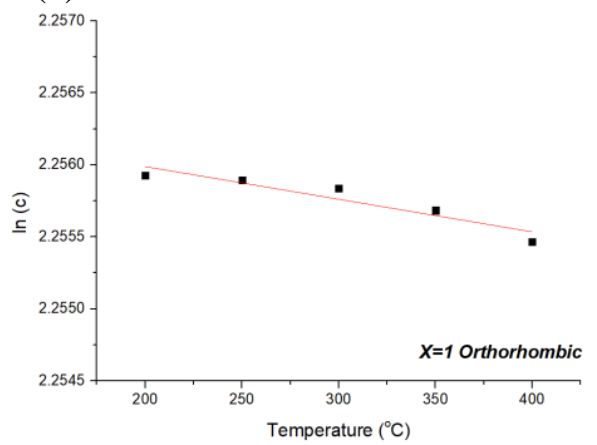

(b)

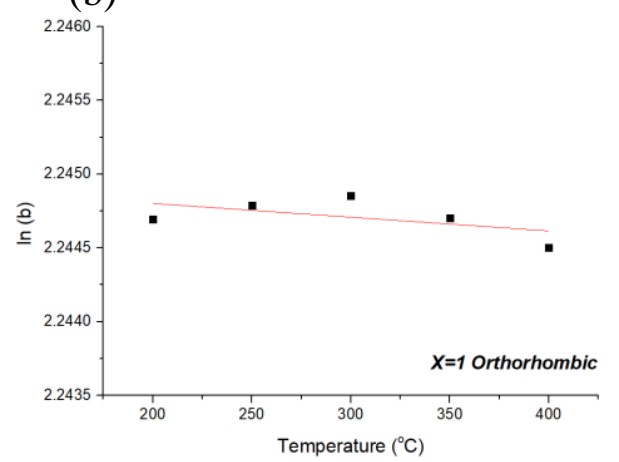

(d)

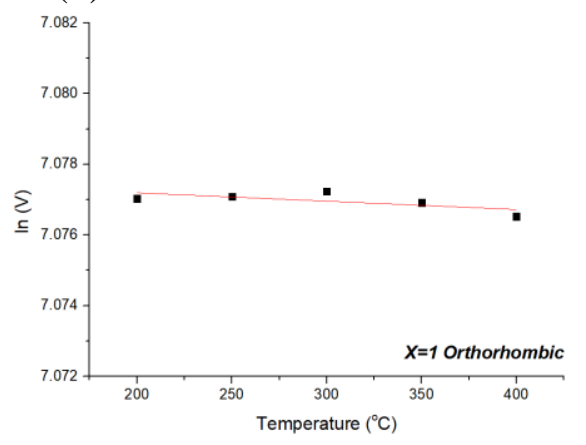

Figure 23- Natural logarithmic variations of unit-cell parameters (a, b and c) and unit-cell volume as function of temperature for $\mathrm{x}=1$ orthorhombic structure in $\mathrm{Al}_{2}$ ${ }_{x} \ln _{x} W_{3} O_{12}$ system. 


\subsection{2.}

\section{Extrinsic CTE}

Dilatometric curves was presented in the 5.2.3. section. The curves obtained for $\mathrm{x}=0.2,0.4$ and 0.7 composition showed positive linear extrinsic CTEs. This values are showed in the Table 8 . The extrinsic CTEs were higher than those obtained by HT-XRPD for intrinsic linear CTE. These differences can be attributed to the fact that the extrinsic CTE accounts also for microstructural contributions. The dilatometry curve for composition $\mathrm{x}=1$ confirmed the existence of phase transition. However, it is worth noting that when this composition adopts orthorhombic structure, it exhibits NZTE (near-zero thermal expansion) above 250 ${ }^{\circ} \mathrm{C}$.

Table 8- Extrinsic linear CTE $\left(\alpha_{l}\right)$ in $\mathrm{Al}_{2-\mathrm{x}} \mathrm{In}_{\mathrm{x}} \mathrm{W}_{3} \mathrm{O}_{12}$ system and their respective standard deviations for $\mathrm{x}=0.2,0.4,0.7$ and 1 compositions.

\begin{tabular}{ccc}
\hline $\begin{array}{c}\boldsymbol{x} \\
\left(\mathbf{I n}^{3+}\right. \\
\text { Content in } \\
\text { Chemical } \\
\text { Formula) }\end{array}$ & $\boldsymbol{\alpha}_{l}\left[{ }^{\mathbf{0}} \mathbf{C}^{-1}\right]$ & $\begin{array}{c}\text { Temperature } \\
\left.\text { Range [ }{ }^{\mathbf{C}}\right]\end{array}$ \\
\hline 0.2 & $4.96 \times 10^{-6}$ & \\
& $\pm 1.8 \times 10^{-7}$ & RT-500 \\
\hline 0.4 & $6.29 \times 10^{-6}$ & RT-500 \\
& $\pm 7.0 \times 10^{-7}$ & \\
\hline 0.7 & $6.00 \times 10^{-6}$ & RT-500 \\
& $\pm 7.0 \times 10^{-7}$ & \\
\hline 1 & $3.18 \times 10^{-6}$ & $250-500$ \\
$(P b c n)$ & $\pm 1.6 \times 10^{-7}$ & \\
\hline
\end{tabular}

\subsection{3.}

\section{CTE in $\mathrm{Al}_{2-\mathrm{x}} \ln _{\mathrm{x}} \mathrm{W}_{3} \mathrm{O}_{12}$ system}

From the results obtained by HT-XRPD (Table 7), it is evident that linear CTEs increased monotonically in the $\mathrm{b}$ and $\mathrm{c}$ axes with the increase in $\mathrm{In}^{3+}$ content until the composition $x=0.7$. On the axis a, the variation (reduction of the unit-cell vector length along a-axes) was not monotonical. This discrepancy can be verified 
by higher-resolution synchrotron radiation technique. The linear CTEs of the compositions $\mathrm{x}=0.2,0.4$ and 0.7 are positive and showed a tendency to increase as the content of $\mathrm{In}^{3+}$ increased in respect to the linear CTE of $\mathrm{Al}_{2} \mathrm{~W}_{3} \mathrm{O}_{12}$ [39].

The intrinsic linear CTE (in relation to the increase of $\mathrm{In}^{3+}$ content) of the compositions $\mathrm{x}=0.2,0.4$ and 0.7 adopted values closer to those reported by Baiz et al. [33] than to those reported by Liu et al. [24] who studied the terminal member $\mathrm{In}_{2} \mathrm{~W}_{3} \mathrm{O}_{12}$ and obtained values of $\alpha_{l}=3.1 \times 10^{-6}{ }^{\circ} \mathrm{C}^{-1}$ and $\alpha_{l}=-3 \times 10^{-6}{ }^{\circ} \mathrm{C}^{-1}$ respectively. The compositions $\mathrm{x}=0.2,0.4$ and 0.7 adopted values of intrinsic CTEs greater than those of the terminal member $\mathrm{Al}_{2} \mathrm{~W}_{3} \mathrm{O}_{12}\left(\alpha_{l}=1.51 \times 10^{-6}{ }^{\circ} \mathrm{C}^{-1}[39]\right)$. This behavior does not allow to obtain NZTE between RT and higher temperatures in the $\mathrm{Al}_{2-\mathrm{x}} \mathrm{In}_{\mathrm{x}} \mathrm{W}_{3} \mathrm{O}_{12}$ system.

On the other hand, the composition $x=1$ presented a high PTE in the monoclinic form $\left(\alpha_{l}=1.88 \times 10^{-5}{ }^{\circ} \mathrm{C}^{-1}\right)$. This high value is close to those reported in others studies of monoclinic forms of $\mathrm{A}_{2} \mathrm{M}_{3} \mathrm{O}_{12}$ [60] [61]. However, when the $\mathrm{AlInW}_{3} \mathrm{O}_{12}$ system adopts an orthorhombic structure, its CTE is close to zero $\left(\boldsymbol{\alpha}_{l}=\right.$ $\left.-7.87 \times 10^{-7}{ }^{\circ} \mathrm{C}^{-1}\right)$.

In the composition $\mathrm{x}=0.7$, it was determined that the intrinsic linear CTE $\left(\alpha_{l}=3.88 \times 10^{-6}{ }^{\circ} \mathrm{C}^{-1}\right)$ was higher than of the terminal member $\operatorname{In}_{2} \mathrm{~W}_{3} \mathrm{O}_{12}$ reported by Baiz et al. [33]. This anomalous behavior was observed in other systems of the $\mathrm{A}_{2} \mathrm{M}_{3} \mathrm{O}_{12}$ family [29] [62].

The behavior of the linear CTEs presented above can be better explained with the octahedral volume distortion model [2] [35]. The linear CTE of $\mathrm{In}_{2} \mathrm{~W}_{3} \mathrm{O}_{12}$ does not fit with cationic radii rationalization and is yet to be assessed in terms of the octahedra volume distortion model; however, it is confirmed by our results that the compositions $\mathrm{x}=0.2,0.4$ and 0.7 in $\mathrm{Al}_{2-\mathrm{x}} \mathrm{In}_{\mathrm{x}} \mathrm{W}_{3} \mathrm{O}_{12}$ system present low positive thermal expansion, as was observed for $\operatorname{In}_{2} \mathrm{~W}_{3} \mathrm{O}_{12}$. On the other hand, when the $\mathrm{AlInW}_{3} \mathrm{O}_{12}$ system adopts an orthorhombic structure, it presents NZTE. This behavior contrasts with the behavior of the other three compositions studied.

The intrinsic and extrinsic CTEs of the orthorhombic compositions $\mathrm{x}=0.2$, 0.4 and 0.7 of the $\mathrm{Al}_{2-\mathrm{x}} \mathrm{In}_{\mathrm{x}} \mathrm{W}_{3} \mathrm{O}_{12}$ system showed a tendency to increase with increasing of $\mathrm{In}^{3+}$ content. The notable difference between extrinsic and intrinsic CTEs can be partially understood as a consequence of the anisotropy of the elastic constants in the $\mathrm{A}_{2} \mathrm{M}_{3} \mathrm{O}_{12}$ family [63]. 


\section{4.}

\section{Higroscopicity}

In order to determine the level of hygroscopicity and possible decomposition of the studied compositions, the thermogravimetry test was carried out. This technique is of great importance and interest because the hygroscopicity of a material can affect the behavior of thermal expansion [37] .

Thermogravimetry was evaluated between RT and $950{ }^{\circ} \mathrm{C}$ for the four studied compositions of the $\mathrm{Al}_{2-\mathrm{x}} \mathrm{In}_{\mathrm{x}} \mathrm{W}_{3} \mathrm{O}_{12}$ system. The curves obtained show that the four compositions have low mass loss, significantly lower than $1 \mathrm{wt} \%$. This behavior classifies these compositions $\mathrm{x}=0.2,0.4,0.7$ and 1 of the $\mathrm{Al}_{2-\mathrm{x}} \mathrm{In}_{\mathrm{x}} \mathrm{W}_{3} \mathrm{O}_{12}$ system as non-hygroscopic materials. The results are shown in Figure 24 and Table 9.

(a)

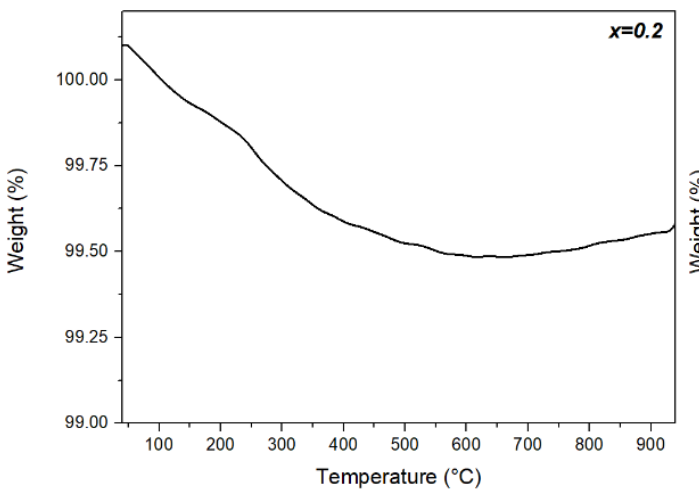

(c)

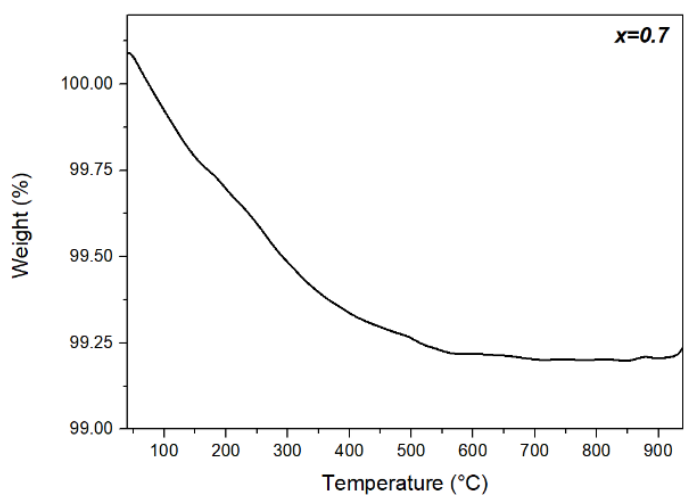

(b)

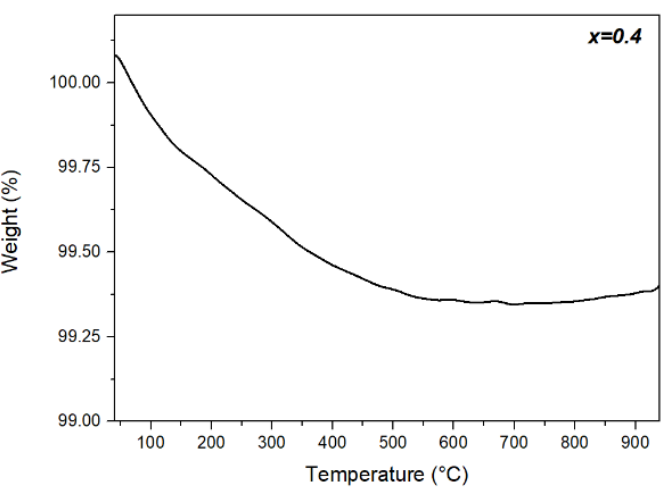

(d)

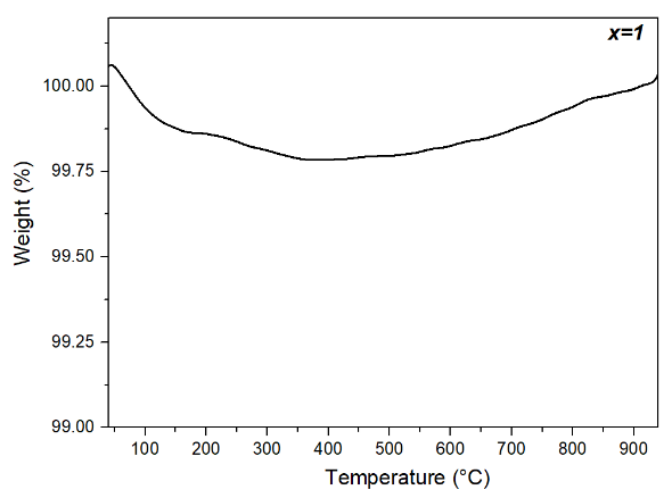

Figure 24- TGA curves of (a) $x=0.2$, (b) $x=0.4$, (c) $x=0.7$ and (d) $x=1$ compositions in $\mathrm{Al}_{2-x} \ln _{x} \mathrm{~W}_{3} \mathrm{O}_{12}$ system. The curves show weight losses lower than $1 \mathrm{wt} \%$, over the temperature range from $\mathrm{RT}$ to $950{ }^{\circ} \mathrm{C}$, for all four phases in $\mathrm{Al}_{2-\mathrm{x}} \mathrm{In}_{\mathrm{x}} \mathrm{W}_{3} \mathrm{O}_{12}$ system. 
Table 9- Weight losses in $\mathrm{Al}_{2-\mathrm{x}} \ln _{\mathrm{x}} \mathrm{W}_{3} \mathrm{O}_{12}$ system for $\mathrm{x}=0.2,0.4,0.7$ and 1 compositions.

\begin{tabular}{cc}
\hline $\begin{array}{c}\boldsymbol{x} \\
\left(\mathbf{I n}^{3+}\right. \\
\text { Content) }\end{array}$ & $\begin{array}{c}\text { Weight } \\
\text { loss [\%] }\end{array}$ \\
\hline 0.2 & 0.5 \\
\hline 0.4 & 0.63 \\
\hline 0.7 & 0.75 \\
\hline 1 & 0.25 \\
\hline
\end{tabular}

Although the $\mathrm{Al}_{2-\mathrm{x}} \mathrm{In}_{\mathrm{x}} \mathrm{W}_{3} \mathrm{O}_{12}$ system presents low hygroscopicity for all compositions studied, it is important to describe that the addition of $\operatorname{~}^{3+}$ lead to variations in the percentage of lost weight. This behavior is due to the difference between the radii of the cations $\mathrm{Al}^{3+}$ and $\mathrm{In}^{3+}$. However, the composition $\mathrm{x}=1$ exhibited the lowest level of hygroscopicity. This behavior is consequence of the fact monoclinic structure is denser than the orthorhombic structure, making it difficult for water molecules to enter it. Low levels of hygroscopicity and a NTE or NZTE behavior increase the applicability of the materials [64].

\section{5 .}

\section{Density of $\mathrm{Al}_{2-\mathrm{x}} \ln _{\mathrm{x}} \mathrm{W}_{3} \mathrm{O}_{12}$}

The relative densities of the sintered pellets were determined for the four compositions taking into account that the compositions $\mathrm{x}=0.2,0.4$ and 0.7 present 4 chemical formulas (orthorhombic structure), and the composition $\mathrm{x}=1$ presented 8 chemical formulas (monoclinic structure). The relative density was calculated from the theoretical density and the density of the sintered bodies samples (described in the 4.2.6). The results are showed in Table 10 and indicated rather high relative densities after conventional sintering. 
Table 10- Theoretical, real and relative densities of the sintered pellets within $\mathrm{Al}_{2}$ ${ }_{x} \ln _{x} \mathrm{~W}_{3} \mathrm{O}_{12}$ system.

\begin{tabular}{cccc}
\hline $\begin{array}{c}\boldsymbol{x} \\
\left(\text { In }^{3+} \text { Content }\right)\end{array}$ & $\begin{array}{c}\text { Theoretical } \\
\text { density } \\
\left(\text { g.cm }^{-3}\right)\end{array}$ & $\begin{array}{c}\text { Density of sintered } \\
\text { bodies } \\
\left(\text { (.cm }^{-3}\right)\end{array}$ & $\begin{array}{c}\text { Relative } \\
\text { density } \\
(\%)\end{array}$ \\
\hline 0.2 & 5.085 & 4.891 & 96.16 \\
0.4 & 5.102 & 5.086 & 99.68 \\
0.7 & 5.044 & 4.939 & 97.92 \\
1 & 5.017 & 4.891 & 97.50 \\
\hline
\end{tabular}

\section{6. \\ Effect of the addition of $\mathrm{In}^{3+}$ cation on the $\mathrm{UV}-\mathrm{Vis}$ absorption in $\mathrm{Al}_{2}$ - $\mathrm{xln}_{\mathrm{x}} \mathrm{W}_{3} \mathrm{O}_{12}$ system}

The constant industrial development has generated a series of problems in the environment. With the aim of finding solutions, investigations of photocatalysis and photodegradation from ceramic materials have been carried out. The study of the band-gap energy (Eg) using UV-vis diffuse reflectance spectroscopy (DRS) technique is one of the most used. However, the value of Eg presents variations considering the type of transition studied, direct or indirect [65] [66]. Band-gap studies have been reported for some members of the $\mathrm{A}_{2} \mathrm{M}_{3} \mathrm{O}_{12}$ family [67] [68] [69].

There are reports of the two end members of the $\mathrm{Al}_{2-\mathrm{x}} \mathrm{In}_{\mathrm{x}} \mathrm{W}_{3} \mathrm{O}_{12}$ system $\left(\mathrm{Al}_{2} \mathrm{~W}_{3} \mathrm{O}_{12}\right.$ [67] and $\mathrm{In}_{2} \mathrm{~W}_{3} \mathrm{O}_{12}$ [68]). Prisco et al. [67] reported that $\mathrm{Al}_{2} \mathrm{~W}_{3} \mathrm{O}_{12}$ presented semiconductor behavior. The synthesized material presented a white color and a band-gap energy $\mathrm{Eg}=3.11 \mathrm{eV}$ (indirect transition). Paiva et al. [68] obtained white powder from $\operatorname{In}_{2} \mathrm{~W}_{3} \mathrm{O}_{12}$ with semiconductor behavior. The authors reported different band-gap energy values for $\operatorname{In}_{2} \mathrm{~W}_{3} \mathrm{O}_{12}$ (direct transition). This behavior was attributed to the $\mathrm{pH}$ level at which the studied samples were synthesized. The results obtained for $\operatorname{In}_{2} \mathrm{~W}_{3} \mathrm{O}_{12}$ are found in Table 11 .

In order to study the partial substitution of $\mathrm{Al}^{3+}$ by $\mathrm{In}^{3+}$, the DRS test was performed for the four compositions of the $\mathrm{Al}_{2-\mathrm{x}} \mathrm{In}_{\mathrm{x}} \mathrm{W}_{3} \mathrm{O}_{12}$ system. DRS was used to study the optical properties in all samples on a Perkin-Elmer Lambda $650 \mathrm{UV}$ vis spectrophotometer, in a range from $800 \mathrm{~nm}$ to $250 \mathrm{~nm}$ in $1 \mathrm{~nm}$ steps. The DRS 
spectra were plotted using the Kubelka-Munk function to estimate the band-gap energy (Appendix A.2.). The results obtained are reported in Table 11.

Table 11- Band-gap energy Eg in $\mathrm{Al}_{2-\mathrm{x}} \mathrm{In}_{\mathrm{x}} \mathrm{W}_{3} \mathrm{O}$ system for $\mathrm{x}=0,0.2,0.4,0.7,1$ and 2 compositions.

\begin{tabular}{|c|c|c|c|c|}
\hline $\begin{array}{c}x \\
\left(\text { In }^{3+} \text { Content }\right)\end{array}$ & $\begin{array}{c}\text { Band gap energy } \\
\text { Eg } \\
{[e V]} \\
\text { Indirect }\end{array}$ & $\begin{array}{c}\text { Band gap energy } \\
\text { Eg } \\
{[e V]} \\
\text { Direct }\end{array}$ & $p H$ & Ref. \\
\hline 0 (Pbcn) & 3.11 & - & 4.0 & [67] \\
\hline $0.2(\mathrm{Pbcn})$ & 3.10 & 3.82 & 4.1 & - \\
\hline $0.4(\mathrm{Pbcn})$ & 3.16 & 3.80 & 4.0 & - \\
\hline 0.7 (Pbcn) & 2.80 & 3.79 & 3.9 & - \\
\hline $1\left(\mathrm{P} 2_{1} / \mathrm{a}\right)$ & 3.35 & 3.78 & 3.7 & - \\
\hline $2\left(\mathrm{P} 2_{1} / \mathrm{a}\right)$ & $\begin{array}{l}- \\
- \\
- \\
- \\
-\end{array}$ & $\begin{array}{l}2.88 \\
2.92 \\
2.95 \\
2.90 \\
3.73\end{array}$ & $\begin{array}{c}2 \\
2.5 \\
3 \\
3.5 \\
4\end{array}$ & [68] \\
\hline
\end{tabular}

From the Kubelka-Munk graphs it could be seen that there were changes in the value of the band-gap energy (Appendix A.2). Regarding the indirect transition, the compositions $\mathrm{x}=0.4$ and 1 exhibited slight increase in the value of the Eg compared to the value of the $\mathrm{Eg}$ of $\mathrm{Al}_{2} \mathrm{~W}_{3} \mathrm{O}_{12}$. However, the compositions $\mathrm{x}=0.2$ and 0.7 presented a lower value of $\mathrm{Eg}$ in relation to the value of $\mathrm{Eg}$ of the $\mathrm{Al}_{2} \mathrm{~W}_{3} \mathrm{O}_{12}$. Although the results indicate that the content of $\mathrm{In}^{3+}$ generated changes in the value of $\mathrm{Eg}$, the results do not follow a pattern.

In the direct transition, the studied compositions of the $\mathrm{Al}_{2-\mathrm{x}} \mathrm{In}_{\mathrm{x}} \mathrm{W}_{3} \mathrm{O}_{12}$ system showed a tendency to approach the Eg value for $\operatorname{In}_{2} \mathrm{~W}_{3} \mathrm{O}_{12}$ with a $\mathrm{pH}=4$ reported by Paiva et al [68]. This $\mathrm{pH}$ level is close to the $\mathrm{pH}$ levels of the studied samples of the $\mathrm{Al}_{2-\mathrm{x}} \mathrm{In}_{\mathrm{x}} \mathrm{W}_{3} \mathrm{O}_{12}$ system. This shows that the increase in the content of $\mathrm{In}^{3+}$ in the system decreases the value of Eg. However, the $\mathrm{pH}$ level at which they were synthesized must be considered. 


\section{6 \\ Conclusions and future works}

- The co-precipitation method provided an adequate synthesis route to obtain single-phased $\mathrm{Al}_{2-\mathrm{x}} \mathrm{In}_{\mathrm{x}} \mathrm{W}_{3} \mathrm{O}_{12}$ with the compositions $\mathrm{x}=0.2$, 0.4, 0.7 and 1. However, there are several processing factors that can vary further affect the properties of the prepared powder, for example: the reaction time and calcination times.

- The results obtained in this study show that $\mathrm{Al}_{2-\mathrm{x}} \mathrm{In}_{\mathrm{x}} \mathrm{W}_{3} \mathrm{O}_{12}$ is not promising for the design of materials with NTE or NZTE. This was determined from obtaining the intrinsic and extrinsic CTEs for the four compositions studied. Compositions $\mathrm{x}=0.2,0.4$ and 0.7 exhibited PTE. The composition $x=1$ presented NTE in the orthorhombic phase. However, this phase is found at temperatures higher than $200{ }^{\circ} \mathrm{C}$. On the other hand, the studied phases present low-positive linear CTE and showed that their values can be adjusted through $\mathrm{Al}^{3+}$ partial substitution by $\operatorname{In}^{3+}$.

- The compositions $\mathrm{x}=0.2,0.4$ and 0.7 of the $\mathrm{Al}_{2-\mathrm{x}} \mathrm{In}_{\mathrm{x}} \mathrm{W}_{3} \mathrm{O}_{12}$ system did not show phase transitions in the range of temperatures in which they were studied $\left(-100{ }^{\circ} \mathrm{C}\right.$ to $\left.500{ }^{\circ} \mathrm{C}\right)$. These three compositions adopted orthorhombic structure along this temperature interval.

- It was determined that the $\mathrm{AlInW}_{3} \mathrm{O}_{12}$ phase adopts monoclinic structure at RT and transforms to orthorhombic at approximately 200 ${ }^{\circ} \mathrm{C}$.

- The suppression of phase transitions for the compositions $\mathrm{x}=0.2,0.4$ and 0.7 , from monoclinic to orthorhombic structure is not in line with the $A^{3+}$ electronegativity rule. Until now this unusual behavior (phase transition suppression between monoclinic and orthorhombic structures) do not have a satisfactory explanation yet. Therefore, it is suggested a further study of this phenomenon in the $\mathrm{Al}_{2-\mathrm{x}} \mathrm{In}_{\mathrm{x}} \mathrm{W}_{3} \mathrm{O}_{12}$ system. 
- The four compositions studied of the $\mathrm{Al}_{2-\mathrm{x}} \mathrm{In}_{\mathrm{x}} \mathrm{W}_{3} \mathrm{O}_{12}$ system presented low hygroscopicity (mass losses $<1$ weight\%). This allows $\mathrm{Al}_{2}$ ${ }_{\mathrm{x}} \mathrm{In}_{\mathrm{x}} \mathrm{W}_{3} \mathrm{O}_{12}$ to be classified as a non-hygroscopic material. 


\section{Referências Bibliográficas}

[1] C.P. Romao, K.J. Miller, C.A. Whitman, M.A. White, B.A. Marinkovic, Negative Thermal Expansion (Thermomiotic) Materials, Elsevier Ltd., 2013. https://doi.org/10.1016/B978-0-08-097774-4.00425-3.

[2] B.A. Marinkovic, M. Ari, R.R. De Avillez, F. Rizzo, F.F. Ferreira, K.J. Miller, M.B. Johnson, M.A. White, Correlation between AO6 polyhedral distortion and negative thermal expansion in orthorhombic Y2Mo3O12 and related materials, Chem. Mater. 21 (2009) 2886-2894. https://doi.org/10.1021/cm900650c.

[3] W. Miller, C.W. Smith, D.S. MacKenzie, K.E. Evans, Negative thermal expansion: A review, J. Mater. Sci. 44 (2009) 5441-5451. https://doi.org/10.1007/s10853-009-3692-4.

[4] M.G. Marzano, Um método para co-precipitação de Y2W3O12 e propriedades físicas do Al2W3O12 consolidado por "spark plasma sintering", 29 (2018) 1-125.

[5] G.D. Barrera, J.A.O. Bruno, T.H.K. Barron, N.L. Allan, Negative thermal expansion, J. Phys. Condens. Matter. 17 (2005). https://doi.org/10.1088/0953-8984/17/4/R03.

[6] H. Liu, W. Sun, Z. Zhang, L. Lovings, C. Lind, Thermal Expansion Behavior in the A2M3O12 Family of Materials, Solids. 2 (2021) 87-107. https://doi.org/10.3390/solids2010005.

[7] P.J. Attfield, Mechanisms and materials for NTE, Front. Chem. 6 (2018) 1 6. https://doi.org/10.3389/fchem.2018.00371.

[8] J.S.O. Evans, Negative thermal expansion materials, J. Chem. Soc. - Dalt. Trans. (1999) 3317-3326. https://doi.org/10.1039/a904297k.

[9] K. Takenaka, Progress of research in negative thermal expansion materials: Paradigm shift in the control of thermal expansion, Front. Chem. 6 (2018) 1-13. https://doi.org/10.3389/fchem.2018.00267.

[10] J.S. Dugadle and D.K.C. MacDonald, The thermal expansion of solids, $\begin{array}{lllll}\text { Philos. } & \text { Mag. } & 89 & \text { (1953) 639-648. }\end{array}$ https://doi.org/10.1080/14786435708242706.

[11] K.J. Miller, M.B. Johnson, M.A. White, B.A. Marinkovic, Low-temperature investigations of the open-framework material HfMgMo $3 \mathrm{O}$ 12, Solid State Commun. 152 (2012) 1748-1752. https://doi.org/10.1016/j.ssc.2012.06.022.

[12] J.S.O. Evans, T.A. Mary, T. Vogt, M.A. Subramanian, A.W. Sleight, Negative thermal expansion in ZrW2O8and HfW 208, Chem. Mater. 8 (1996) 2809-2823. https://doi.org/10.1021/cm9602959.

[13] H. Birkedal, A.M.K. Andersen, A. Arakcheeva, G. Chapuis, P. Norby, P. Pattison, The room-temperature superstructure of $\mathrm{ZrP} 2 \mathrm{O} 7$ is orthorhombic: There are no unusual $180^{\circ} \mathrm{P}-\mathrm{O}-\mathrm{P}$ bond angles, Inorg. Chem. 45 (2006) 4346 4351. https://doi.org/10.1021/ic0600174.

[14] K.M. White, P.L. Lee, P.J. Chupas, K.W. Chapman, E.A. Payzant, A.C. Jupe, W.A. Bassett, C.S. Zha, A.P. Wilkinson, Synthesis, symmetry, and 
physical properties of cerium pyrophosphate, Chem. Mater. 20 (2008) 3728 3734. https://doi.org/10.1021/cm702338h.

[15] L. Sebastian, S. Sumithra, J. Manjanna, A.M. Umarji, J. Gopalakrishnan, Anomalous thermal expansion behaviour of Ln2Mo4O 15 ( $\mathrm{Ln}=\mathrm{Y}$, Dy, Ho, Tm), Mater. Sci. Eng. B Solid-State Mater. Adv. Technol. 103 (2003) 289296. https://doi.org/10.1016/S0921-5107(03)00285-X.

[16] T.G. Amos, A.W. Sleight, Negative thermal expansion in orthorhombic NbOPO4, J. Solid State Chem. $160 \quad$ (2001) 230-238. https://doi.org/10.1006/jssc.2001.9227.

[17] M. Dapiaggi, A.N. Fitch, Negative (and very low) thermal expansion in $\mathrm{ReO} 3$ from 5 to $300 \mathrm{~K}$, J. Appl. Crystallogr. 42 (2009) 253-258. https://doi.org/10.1107/S002188980804332X.

[18] J.S.O. Evans, T.A. Mary, A.W. Sleight, Negative Thermal Expansion in a Large Molybdate and Tungstate Family, J. Solid State Chem. 133 (1997) 580-583. https://doi.org/10.1006/jssc.1997.7605.

[19] T.A. Mary; A.W. Sleight. 1999., Bulk thermal expansion for tungsatte and molybdates of the type A2M3O12., (n.d.). https://doi.org/10.1557/JMR.1999.0122.

[20] T. Suzuki, A. Omote, Negative thermal expansion in (HfMg)(WO4)3, J. Am. Ceram. Soc. 87 (2004) 1365-1367. https://doi.org/10.1111/j.11512916.2004.tb07737.x.

[21] T.I. Baiz, A.M. Gindhart, S.K. Kraemer, C. Lind, Synthesis of MgHf(WO4)3 and $\mathrm{MgZr}(\mathrm{WO} 4) 3$ using a non-hydrolytic sol-gel method, J. Sol-Gel Sci. Technol. 47 (2008) 128-130. https://doi.org/10.1007/s10971-008-1765-5.

[22] T.M. Machado, I.L. Muller Costa, A. Dosen, G.S. Lima de Faro Melo, L.E. Vasconcellos, B.A. Marinkovic, Hygroscopicity, phase transition and thermal expansion in Yb2-xGaxW3O12 system, J. Alloys Compd. 854 (2021). https://doi.org/10.1016/j.jallcom.2020.156643.

[23] N. Dasgupta, E. Sörge, B. Butler, T.C. Wen, D.K. Shetty, L.R. Cambrea, D.C. Harris, Synthesis and characterization of $\mathrm{Al} 2-\mathrm{xSc} x(\mathrm{WO} 4) 3$ ceramics for low-expansion infrared-transmitting windows, J. Mater. Sci. 47 (2012) 6286-6296. https://doi.org/10.1007/s10853-012-6548-2.

[24] H. Liu, Z. Zhang, J. Ma, Z. Jun, X. Zeng, Effect of isovalent substitution on phase transition and negative thermal expansion of In2-xScxW3O12 ceramics, Ceram. Int. $41 \quad$ (2015) 9873-9877. https://doi.org/10.1016/j.ceramint.2015.04.062.

[25] Z. Zhang, Y. Wang, W. Sun, X. Zhang, H. Liu, X. Chen, X. Zeng, Phase transition temperature and negative thermal expansion of Sc-substituted In2(MoO4)3 ceramics, J. Mater. Sci. 55 (2020) 5730-5740. https://doi.org/10.1007/s10853-020-04441-9.

[26] Z. Yu, J. Peng, H. Wang, M. Wu, Y. Cheng, Z. Hu, D. Chen, Thermal expansion properties and hygroscopicity of Y2-x Sm x W3O12 ( $\mathrm{x}=0.0-0.4)$ compounds, Sci. China, Ser. E Technol. Sci. 51 (2008) 25-32. https://doi.org/10.1007/s11431-007-0040-2.

[27] W. Sun, Z. Zhang, H. Liu, W. Wang, X. Zeng, Tailored phase transition temperature and negative thermal expansion of Sc-substituted Fe2Mo3O12 synthesized by the co-precipitation method, J. Alloys Compd. 794 (2019) 17. https://doi.org/10.1016/j.jallcom.2019.04.229.

[28] Z.Y. Li, W.B. Song, E.J. Liang, Structures, phase transition, and crystal water of Fe2- xY xMo3O12, J. Phys. Chem. C. 115 (2011) 17806-17811. 
https://doi.org/10.1021/jp201962b.

[29] M. Ari, P.M. Jardim, B.A. Marinkovic, F. Rizzo, F.F. Ferreira, Thermal expansion of $\mathrm{Cr} 2 \mathrm{xFe} 2-2 \mathrm{xMo} 3 \mathrm{O} 12, \mathrm{Al} 2 \mathrm{xFe} 2-2 \mathrm{xMo} 3 \mathrm{O} 12$ and $\mathrm{Al} 2 \mathrm{xCr} 2-$ 2xMo3O12 solid solutions, J. Solid State Chem. 181 (2008) 1472-1479. https://doi.org/10.1016/j.jssc.2008.03.015.

[30] I. Koseva, A. Yordanova, V. Nikolov, High-Density Ceramics of Al\&lt;sub\&gt;2-x\&lt;/sub\&gt;Me\&lt;sub\&gt;x\&lt;/sub\&gt;

(WO\&lt;sub\&gt;4\&lt;/sub\&gt;)\&lt;sub\&gt;3\&lt;/sub\&gt;, (Me = Sc or In) Solid Solutions, New J. Glas. Ceram. 03 (2013) 104-110. https://doi.org/10.4236/njgc.2013.34017.

[31] H. Liu, W. Sun, Z. Zhang, M. Zhou, X. Meng, Tailorable thermal expansion and hygroscopic properties of cerium- substituted Y $2 \mathrm{~W} 3 \mathrm{O} 12$ ceramics, J. $\begin{array}{lllll}\text { Alloys } & \text { Compd. } & 751 & \text { (2018) }\end{array}$ https://doi.org/10.1016/j.jallcom.2018.04.081.

[32] J. Zhang, J. Pan, J. Yin, J. Wang, J. Pan, H. Chen, R. Mao, Structural investigation and scintillation properties of Cd1-xZnxWO4 solid solution single crystals, CrystEngComm. $17 \quad$ (2015) 3503-3508. https://doi.org/10.1039/c4ce02544j.

[33] T.I. Baiz, C.P. Heinrich, N.A. Banek, B.L. Vivekens, C. Lind, In-situ nonambient X-ray diffraction studies of indium tungstate, J. Solid State Chem. 187 (2012) 195-199. https://doi.org/10.1016/j.jssc.2012.01.019.

[34] L.P. Prisco, P.I. Pontón, W. Paraguassu, C.P. Romao, M.A. White, B.A. Marinkovic, Near-zero thermal expansion and phase transition in In0.5(ZrMg)0.75Mo3O12, J. Mater. Res. 31 (2016) 3240-3248. https://doi.org/10.1557/jmr.2016.329.

[35] A. Perras, U. Werner-zwanziger, J.A. Lussier, K.J. Miller, C.M. Calahoo, J.W. Zwanziger, M. Bieringer, B.A. Marinkovic, D.L. Bryce, M.A. White, Zero Thermal Expansion in ZrMgMo 3 O 12: NMR Crystallography Reveals Origins of Thermoelastic Properties, (2015). https://doi.org/10.1021/acs.chemmater.5b00429.

[36] R. Allada, A. Maruthapillai, K. Palanisamy, P. Chappa, Hygroscopicity Categorization of, 10 (2016) 279-286.

[37] S. Sumithra, A.M. Umarji, Hygroscopicity and bulk thermal expansion in Y $\begin{array}{llllllll}2 & \mathrm{~W} & 3 & \mathrm{O} & 12, & 40 & \text { (2005) }\end{array}$ https://doi.org/10.1016/j.materresbull.2004.09.009.

[38] A.W. Sleight, L.H. Brixner, A New Ferroelastic Transition in Some A , ( MO , J , Tungstates, 74 (1973) 172-174.

[39] D.A. Woodcock, P. Lightfoot, C. Ritter, Negative Thermal Expansion in Y 2 ( WO 4 ) 3, 98 (2000) 92-98.

[40] N. Imanaka, M. Hiraiwa, G. Adachi, H. Dabkowska, A. Dabkowski, Thermal contraction behavior in Al ( WO ) single crystal, 220 (2000) 176-179.

[41] V. Sivasubramanian, T.R. Ravindran, R. Nithya, A.K. Arora, Structural phase transition in indium tungstate, J. Appl. Phys. 96 (2004) 387-392. https://doi.org/10.1063/1.1757659.

[42] L.P. Prisco, P.I. Pont, R.R. Avillez, C.P. Romao, M.B. Johnson, M.A. White, B.A. Marinkovic, Assessment of the Thermal Shock Resistance Figures of Merit, 1748 (2016) 1742-1748. https://doi.org/10.1111/jace.14160.

[43] P. Tzvetkov, D. Ivanova, D. Kovacheva, V. Nikolov, Synthesis and powder XRD characterization of Al2-xInx(WO4)3 solid solutions, J. Alloys Compd. 470 (2009) 492-496. https://doi.org/10.1016/j.jallcom.2008.03.004. 
[44] I. Koseva, A. Yordanova, P. Tzvetkov, V. Nikolov, D. Nihtianova, Nanosized pure and Cr doped Al2-xInx(WO 4)3 solid solutions, Mater. Chem. Phys. 132 (2012) 808-814. https://doi.org/10.1016/j.matchemphys.2011.12.016.

[45] A.S. Yordanova, V.S. Nikolov, I.I. Koseva, Fabrication of high density ceramic from Al2-XInX(WO4)3 solid solutions, J. Chem. Technol. Metall. 50 (2015) 537-542.

[46] M.W. Hussain, M. Yousuf, H. Ansari, Significance and Importance of Thermal Expansion:, 9 (2017) 68-73. https://doi.org/10.9790/48610905026873.

[47] D.C. Harris, Optical Properties of Infrared Windows, 2010. https://doi.org/10.1117/3.349896.ch2.

[48] P.M. V Raja, A.R. Barron, PHYSICAL METHODS IN CHEMISTRY AND, (n.d.).

[49] J. Li, X. Sun, S. Liu, X. Li, J. Li, D. Huo, A homogeneous co-precipitation method to synthesize highly sinterability YAG powders for transparent ceramic, Ceram. Int. (2014). https://doi.org/10.1016/j.ceramint.2014.10.076.

[50] M.N. Rahaman, Sintering of ceramics, Sinter. Ceram. i (2007) 1-389. https://doi.org/10.1201/b15869-2.

[51] A.K. Tyagi, S.N. Achary, M.D. Mathews, Phase transition and negative thermal expansion in A(MoO4)3 system., 339 (2002) 207-210.

[52] T.H. and Y.M. Takayu SUGIMOTO, Yuhshi AOKI, Eiki Niwa, Thermal Expansion and Phase transition and Transition Behavior of Al2-xMx (WO4)3 Ceramics, J. Ceram. Soc. Japan. 181 (2007) 176-181.

[53] T. Hashimoto, T. Sugimoto, K. Omoto, N. Kineri, Y. Ogata, K. Tsuda, Analysis of phase transition and expansion behaviour of Al 2(WO4)3 by temperature-regulated X-ray diffraction, Phys. Status Solidi Basic Res. 245 (2008) 2504-2508. https://doi.org/10.1002/pssb.200880258.

[54] J.S.O. Evans, T.A. Mary, A.W. Sleight, Negative Thermal Expansion in Sc2(WO4)3, J. Solid State Chem. 137 (1998) 148-160. https://doi.org/10.1006/jssc.1998.7744.

[55] L.R. K. T. Jacob, Shubhra Raj, Vegard' s law : a fundamental relation, Int. J. Mater. Res. 98 (2007) 776-779.

[56] R.D. SHANNON, Revised Effective Ionic Radii and Systematic Studies of Interatomie Distances in Halides and Chaleogenides, J. Acta Crystallogr. $\begin{array}{lllll}\text { A32, } & 751 . & 10 & \text { (1976) }\end{array}$ https://doi.org/https://doi.org/10.1107/S0567739476001551.

[57] R. Truitt, I. Hermes, A. Main, A. Sendecki, C. Lind, Low temperature synthesis and characterization of AlScMo3O12, Materials (Basel). 8 (2015) 700-716. https://doi.org/10.3390/ma8020700.

[58] T. Varga, J.L. Moats, S. V. Ushakov, A. Navrotsky, Thermochemistry of A2M3O12 negative thermal expansion materials, J. Mater. Res. 22 (2007) 2512-2521. https://doi.org/10.1557/jmr.2007.0311.

[59] J. Zhu, J. Yang, X. Cheng, Synthesis and tunable thermal expansion property of Al $2-\delta \mathrm{Sc} \delta \mathrm{W} 3 \mathrm{O} 12$, Solid State Sci. 14 (2012) 187-190. https://doi.org/10.1016/j.solidstatesciences.2011.11.023.

[60] B.A. Marinkovic, M. Ari, P.M. Jardim, R.R. de Avillez, F. Rizzo, F.F. Ferreira, In2Mo3O12: A low negative thermal expansion compound, $\begin{array}{lllll}\text { Thermochim. } & \text { Acta. } & 499 & \text { (2010) }\end{array}$ https://doi.org/10.1016/j.tca.2009.10.021. 
[61] J.S.O. Evans, T.A. Mary, Structural phase transitions and negative thermal expansion in Sc2(MoO4)3, Int. J. Inorg. Mater. 2 (2000) 143-151. https://doi.org/10.1016/S1466-6049(00)00012-X.

[62] J. Liu, H.E. Maynard-Casely, H.E.A. Brand, N. Sharma, Sc1.5A10.5W3O12Exhibits Zero Thermal Expansion between 4 and $1400 \mathrm{~K}$, Chem. Mater. $33 \quad$ (2021) 3823-3831. https://doi.org/10.1021/acs.chemmater.1c01007.

[63] C.P. Romao, S.P. Donegan, J.W. Zwanziger, M.A. White, Relationships between elastic anisotropy and thermal expansion in A2Mo3O12 materials, Phys. Chem. Chem. Phys. 18 (2016) 30652-30661. https://doi.org/10.1039/c6cp06356j.

[64] W.B. Song, E.J. Liang, X.S. Liu, Z.Y. Li, B.H. Yuan, J.Q. Wang, A negative thermal expansion material of ZrMgMo3O12, Chinese Phys. Lett. 30 (2013). https://doi.org/10.1088/0256-307X/30/12/126502.

[65] R. López, R. Gómez, Band-gap energy estimation from diffuse reflectance measurements on sol-gel and commercial TiO 2: A comparative study, J. Sol-Gel Sci. Technol. 61 (2012) 1-7. https://doi.org/10.1007/s10971-0112582-9.

[66] L.A. Almeida, M. Habran, R.D.S. Carvalho, M.E.H.M. da Costa, M. Cremona, B.C. Silva, K. Krambrock, O.G. Pandoli, E. Morgado, B.A. Marinkovic, The influence of calcination temperature on photocatalytic activity of $\mathrm{TiO} 2$-acetylacetone charge transfer complex towards degradation of Nox under visible light, Catalysts. 10 (2020) 1-18. https://doi.org/10.3390/catal10121463.

[67] L.P. Prisco, M. Marzano, P.I. Pontón, A.M.L.M. Costa, C.A. da Costa Neto, G. Sweet, C.P. Romao, M.A. White, B.A. Marinkovic, Relationship between sintering methods and physical properties of the low positive thermal expansion material A12W3O12, Int. J. Appl. Ceram. Technol. 16 (2019) 346-356. https://doi.org/10.1111/ijac.13054.

[68] R.T. De Paiva, I.C. Nogueira, J.C. Sczancoski, P.S. Lemos, J.M.E. Matos, R.S. Santos, E. Longo, L.S. Cavalcante, Effect of the $\mathrm{pH}$ pre-adjustment on the formation of In2W3O12 and In6WO12 powders: Cluster coordination and optical band gap, Bol. La Soc. Esp. Ceram. y Vidr. 59 (2020) 2-14. https://doi.org/10.1016/j.bsecv.2019.02.001.

[69] M. Yadagiri, S. Ramakrishna, G. Ravi, P. Suresh, K. Sreenu, M. Vithal, PREPARATION , CHARACTERIZATION AND PHOTOCATALYTIC, 9 (2015) 391-399. 
Appendix A: Supplementary material to support section $\mathbf{5 . 6}$

\section{A.1.}

TGA-DSC curves in amorphous $\mathrm{Al}_{2-\mathrm{x}} \mathrm{In}_{\mathrm{x}} \mathrm{W}_{3} \mathrm{O}_{12}$ powders with $\mathrm{x}=0.2,0.4,0.7$ and 1 compositions.

(a)

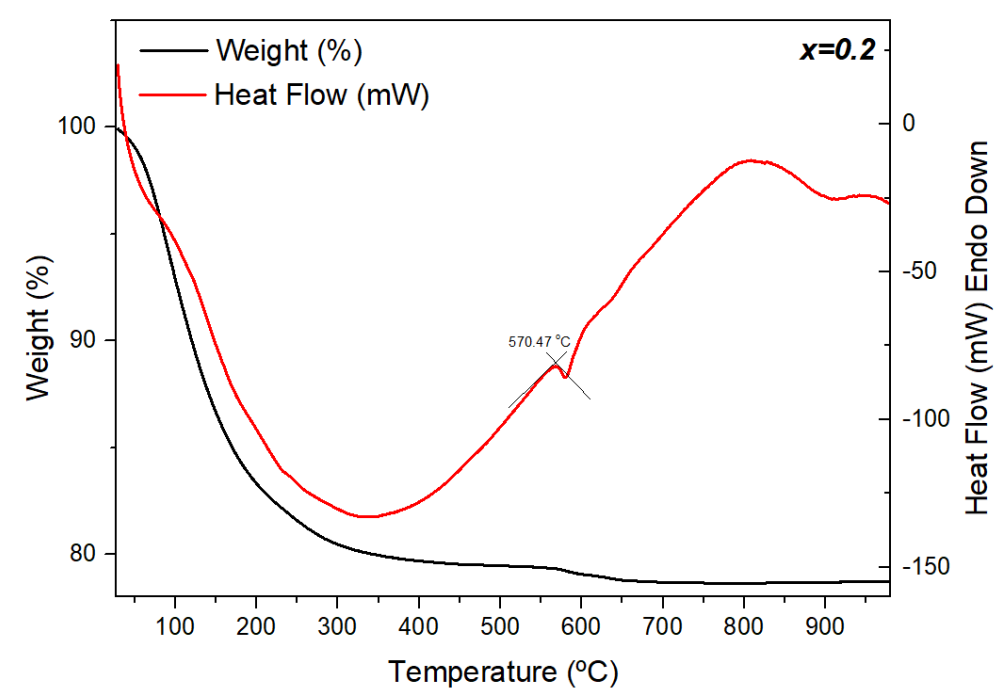

(b)

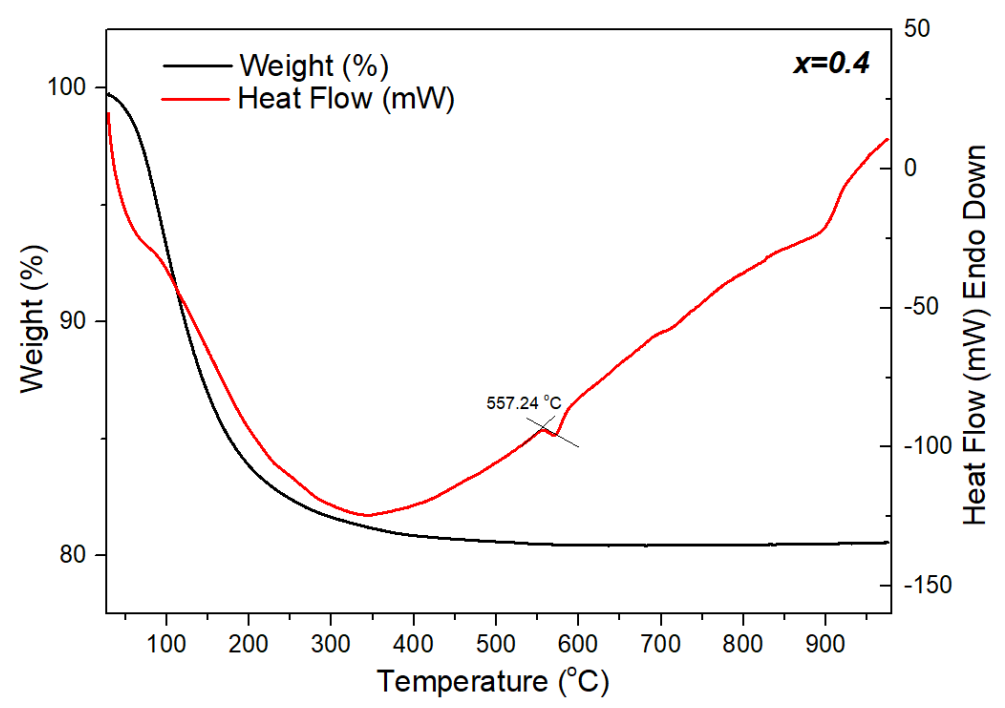


(c)

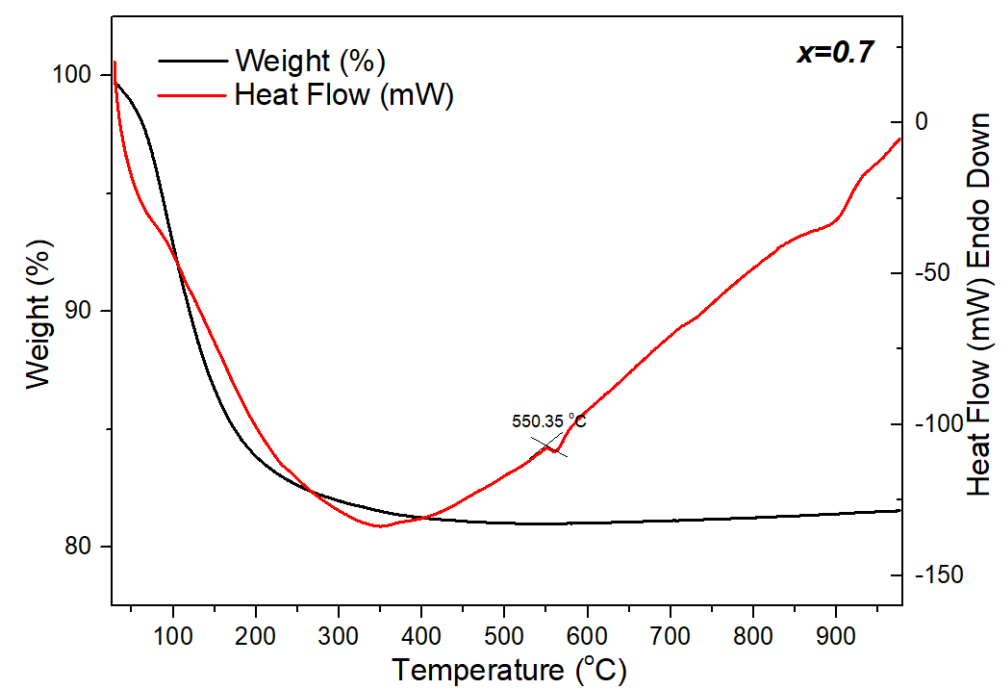

(d)

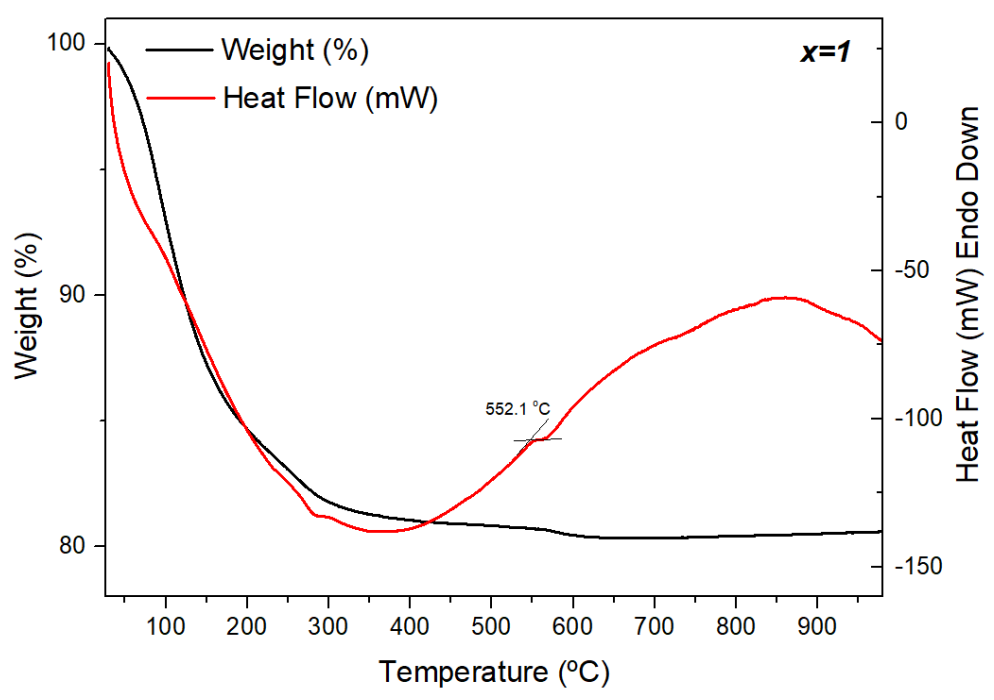

Figure A.1 - TGA-DSC curves in amorphous $\mathrm{Al}_{2-x} \ln _{x} \mathrm{~W}_{3} \mathrm{O}_{12}$ powders with (a) $x=0.2$, (b) $x=0.4$, (c) $x=0.7$ and (d) $x=1$ compositions. 
A.2.

Kubelka-Munj curves of $\mathrm{Al}_{2-\mathrm{x}} \ln _{\mathrm{x}} \mathrm{W}_{3} \mathrm{O}_{12}$ system with $\mathrm{x}=0.2,0.4$,

0.7 and 1 compositions.

(a)
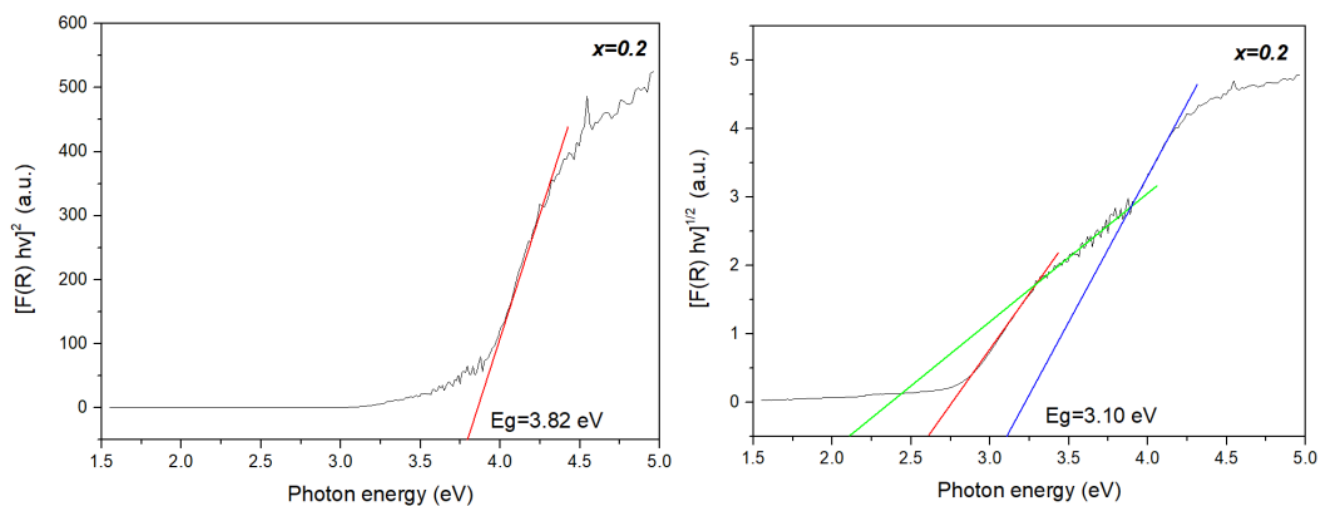

(b)
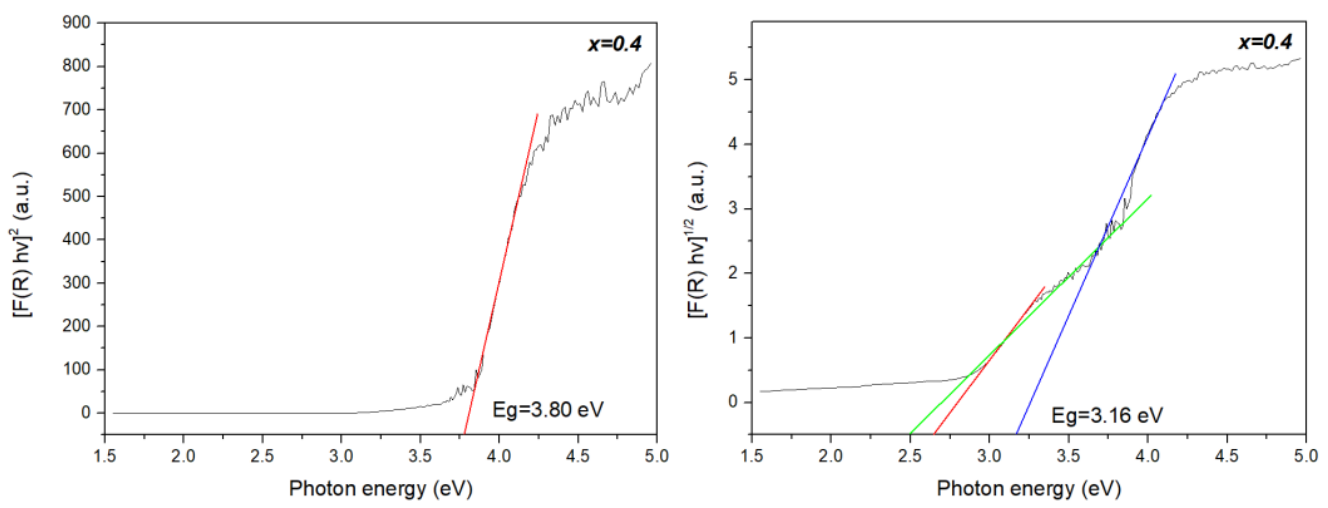

(c)
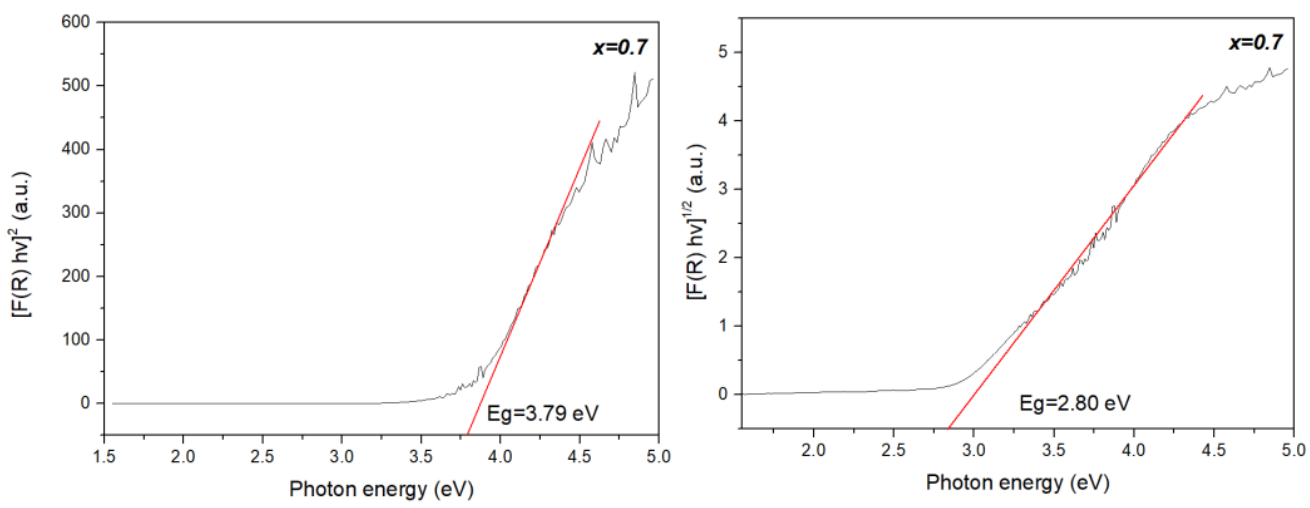
(d)
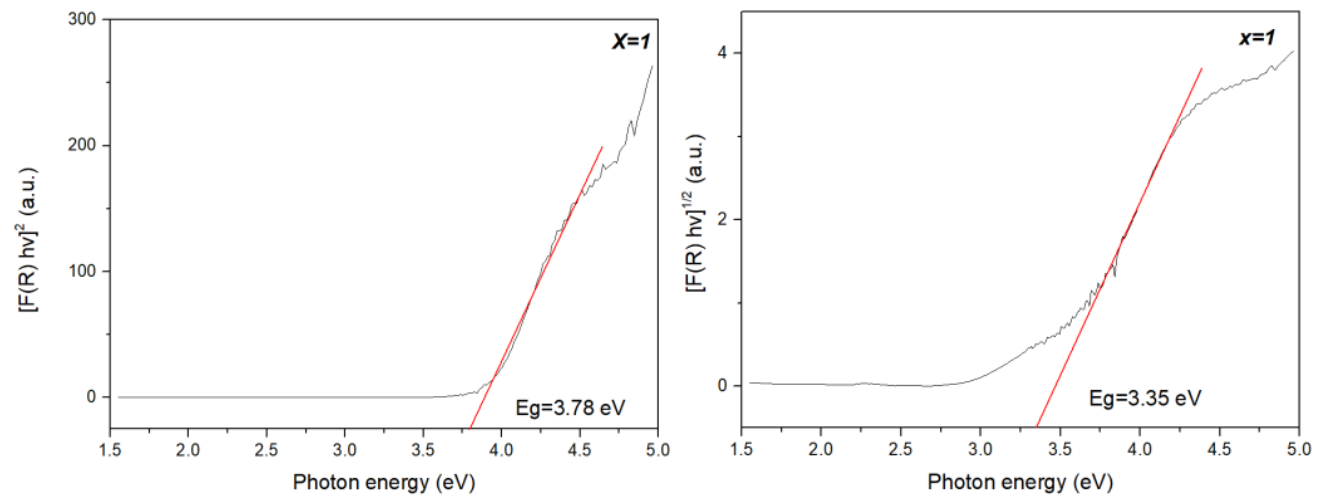

Figure A.2 - Kubelka-Munj curves of $\mathrm{Al}_{2-\mathrm{x}} \ln _{\mathrm{x}} \mathrm{W}_{3} \mathrm{O}_{12}$ system. Direct (left) and indirect (right) transition for (a) $x=0.2$, (b) $x=0.4$, (c) $x=0.7$ and (d) $x=1$. 


\title{
Appendix B: Article published from the results from this Dissertation
}

An article was recently published, based on the results reported and discussed in this Dissertation. Materials (Qualis: A2) as: CERÓN CORTÉS, ANDRÉS ESTEBAN; DOSEN, ANJA; BLAIR, VICTORIA L.; JHONSON, MICHEL B.; WHITE, MARY ANNE; Marinkovic, Bojan A. Phase Transition and Coefficients of Thermal Expansion in Al2-xInxW3O12 $(0.2 \leq \mathrm{x} \leq 1)$. Materials scr, v. 14, p. 4021, 2021.

https://doi.org/10.3390/ma14144021

\author{
Phase Transition and Coefficients of Thermal Expansion in \\ $\mathrm{Al2}-\mathrm{xInxW3O12}(0.2 \leq \mathrm{x} \leq 1)$
}

Materials, v. 14, p. 4021, 2021.

Andrés Esteban Cerón Cortés ${ }^{1}$, Anja Dosen ${ }^{1}$, Victoria L. Blair ${ }^{2}$, Michel B. Johnson ${ }^{3}$, Mary Anne White ${ }^{3,4}$ and Bojan A. Marinkovic ${ }^{1, *}$

1 Department of Chemical and Materials Engineering, Pontifical Catholic University of Rio de Janeiro (PUC-Rio), Rio de Janeiro 22453-900, Brazil; ceron@aluno.puc-rio.br (A.E.C.C.); adosen@puc-rio.br (A.D.)

2 DEVCOM Army Research Laboratory, 6300 Rodman Rd. APG, Adelphi, MD 21005, USA; victoria.1.blair3.civ@mail.mil

3 Clean Technologies Research Institute, Dalhousie University, Halifax, NS B3H 4R2, Canada; michel.johnson@Dal.Ca (M.B.J.); mary.anne.white@dal.ca (M.A.W.)

4 Department of Chemistry, Dalhousie University, Halifax, NS B3H 4R2, Canada 